University of Louisville

ThinkIR: The University of Louisville's Institutional Repository

$8-2012$

\title{
Pivotal role of Interleukin-10 on microRNA-155 expression in regulation of the monocyte response in hypothermia.
}

Adrian Theophil Billeter 1984-

University of Louisville

Follow this and additional works at: https://ir.library.louisville.edu/etd

\section{Recommended Citation}

Billeter, Adrian Theophil 1984-, "Pivotal role of Interleukin-10 on microRNA-155 expression in regulation of the monocyte response in hypothermia." (2012). Electronic Theses and Dissertations. Paper 109.

https://doi.org/10.18297/etd/109

This Doctoral Dissertation is brought to you for free and open access by ThinkIR: The University of Louisville's Institutional Repository. It has been accepted for inclusion in Electronic Theses and Dissertations by an authorized administrator of ThinkIR: The University of Louisville's Institutional Repository. This title appears here courtesy of the author, who has retained all other copyrights. For more information, please contact thinkir@louisville.edu. 


\title{
PIVOTAL ROLE OF INTERLEUKIN-10 ON MICRORNA-155 EXPRESSION IN REGULATION OF THE MONOCYTE RESPONSE IN HYPOTHERMIA
}

\author{
By \\ Adrian Theophil Billeter M.D. \\ University of Zurich 2009 \\ A Dissertation \\ Submitted to the Faculty of the \\ School of Medicine of the University of Louisville \\ In Partial Fulfillment of the Requirements \\ For the Degree of \\ Doctor of Philosophy \\ Department of Physiology and Biophysics \\ University of Louisville \\ Louisville, Kentucky
}

August 2012 
Copyright 2012 by Adrian Theophil Billeter

All rights reserved 
PIVOTAL ROLE OF INTERLEUKIN-10 ON MICRORNA-155 EXPRESSION IN REGULATION OF THE MONOCYTE RESPONSE IN HYPOTHERMIA

By

Adrian Theophil Billeter, M.D.

University of Zurich 2009

A Dissertation Approved on

July 26,2012

By the following Dissertation Committee:

Hiram C. Polk, Jr., M.D., Dissertation Director

Gary Anderson

Irving Joshua

Stanley D'Souza

Aruni Bhatnagar 


\section{ACKNOWLEDGMENTS}

This dissertation is dedicated to my parents, Maja and Theophil, for their strong support and for believing in me, and my mentor Hiram C. Polk Jr., M.D. I learned more from Dr. Polk than I could ever imagine and more than many will learn in a lifetime. His dedication to clinical work, research and mentoring of young surgeons like me has become a personal standard to which I try to aspire.

I would like to express my deepest gratitude to Matthias Turina, M.D. Ph.D. He introduced me to research at the first place and made it possible that I have this great opportunity to be part of this program. He is a good friend and is always willing to help and give his best suggestions.

I am grateful to Dr. Susan Galandiuk for the opportunity to work at the Price Institute of Surgical Research and for contributing her thoughts and ideas throughout my studies. Ms. Sarah A. Gardner and Mr. Devin Druen also deserve my gratitude. Without their dedicated work, I would not have been able to succeed in my studies. Furthermore, Dr. Ziad M. Kanaan and Mr. Robert Eichenberger deserve my gratitude for their guidance and introduction to the world of microRNAs. In addition, I am grateful to all my committee members Dr. Irving Joshua, Dr. Gary Anderson and Dr. Stanley E. D'Souza from the Department of Physiology and Biophysics for their help and advice. 
I would like to thank Dr. Aruni Bhatnagar for his guidance as committee member but especially for the opportunity to conduct animal experiments in his laboratory. Without the guidance, advice and support of Dr. Matthew R. Spite and Dr. Jason Hellmann, conducting these promising animal experiments would not have been possible. I am look forward to the final results of our experiments and further collaboration.

Lastly, I wish to thank the Royal College of Surgeons of Edinburgh (RCSEd) and the James and Emmeline Ferguson Research Fellowship Trust without whose generosity my work would not have been possible. A special thank you goes to Mr. and Mrs. R. Bruce Bass for their on-going generosity to their family trust, the Price Institute itself. 


\title{
ABSTRACT \\ PIVOTAL ROLE OF INTERLEUKIN-10 ON MICRORNA-155 EXPRESSION IN REGULATION OF THE MONOCYTE RESPONSE IN HYPOTHERMIA
}

\author{
Adrian Theophil Billeter
}

July 26,2012

This project investigated the effect of hypothermia on the monocyte response with the goal of understanding, which intracellular processes are affected by hypothermia leading to differences in cytokine secretion. A better understanding of the effects of hypothermia on the regulation of monocyte responses would allow targeted interventions and may reduce complications and death in hypothermic surgical patients. We found the following results:

1. The three major pro-inflammatory signaling pathways, Nuclear Factor $k \beta$, p38 and C-Jun N-terminal-Kinase (JNK) of the Mitogen Activated Protein Kinases pathway, have increased and prolonged activation with hypothermia $\left(32^{\circ} \mathrm{C}\right)$. The extracellular signal-related kinase (Erk) pathway shows increased activation at 15 minutes at $39^{\circ} \mathrm{C}$. 
2. The prolonged and increased activation of the pro-inflammatory signaling pathways results in a prolonged and increased expression of TNF-a messenger RNA (mRNA) and protein and microRNA-155 at $32^{\circ} \mathrm{C}$.

3. Increased activation of Erk at $39^{\circ} \mathrm{C}$ leads to induction of Interleukin-10 mRNA and production of IL-10 protein.

4. The high $\mathrm{IL}-10$ protein levels at $39^{\circ} \mathrm{C}$ result in suppression of the microRNA-155 expression, whereas the lack of $\mathrm{IL}-10$ at $32^{\circ} \mathrm{C}$ prolongs microRNA-155 expression.

5. The increased and prolonged expression of microRNA-155 results in increased and prolonged TNF-a production at $32^{\circ} \mathrm{C}$.

The findings of our research demonstrate the importance of regulatory feedback loops in order to achieve a balanced immune response. The lack of the inhibitory $\mathrm{IL}-10$ at $32^{\circ} \mathrm{C}$ results in a prolonged pro-inflammatory response, which may have detrimental effects on host defense with a subsequently increased susceptibility to infections and organ dysfunction. The improved understanding of the intracellular mechanisms involved in the regulation of the monocyte response may result in targeted interventions to ameliorate the detrimental effects of hypothermia. 
TABLE OF CONTENTS

Page

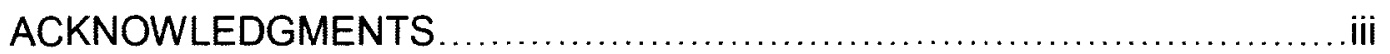

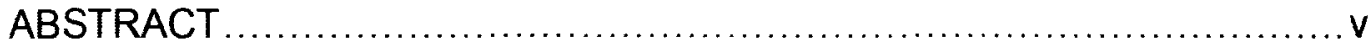

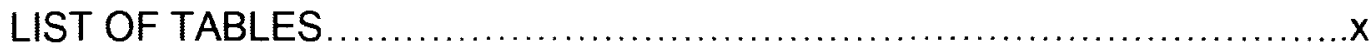

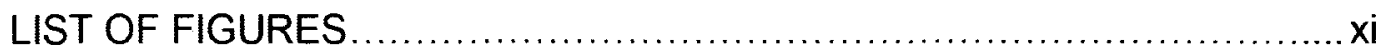

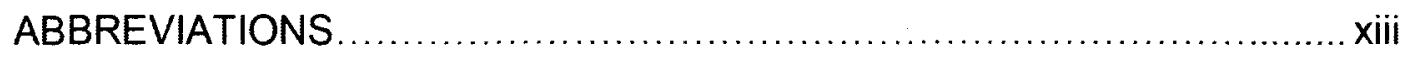

\section{CHAPTER}

I. INTRODUCTION ...................................................... 1

II. GENERAL OVERVIEW................................................ 3

A. Clinical Importance of Hypothermia .............................. 3

B. Overview of the Immune Response ............................ 7

i. Monocytes, Macrophages, Dendritic Cells and Their Relationship.................................................. 8

ii. Sequence of the Immune Response........................ 11

iii. Role of Cytokines in the Immune Response ................ 12

C. Role and Regulation of the Monocyte ............................. 17

i. Pathogen Recognition and Intracellular Signaling ..............18

ii. NF-KB and MAPK-Pathway ............................... 19

D. MicroRNAs Regulate the Monocyte Response .................... 24

i. MicroRNAs Described in Monocytes .......................... 25 
ii. Considerations of Target Protein and Timing for Action of MicroRNAs................................................ 30

E. Effect of Temperature on the Monocyte Response............... 31

III. HYPOTHESIS AND EXPERIMENTAL PLAN ............................35

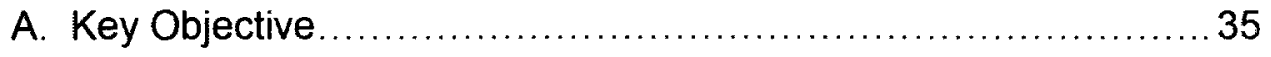

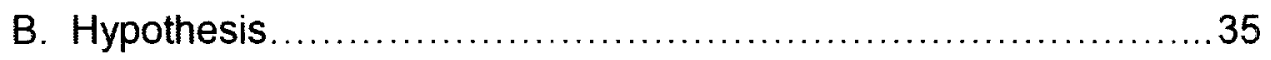

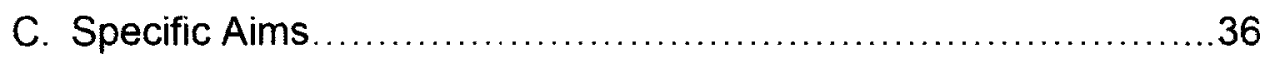

D. Experimental Plan .................................................... 36

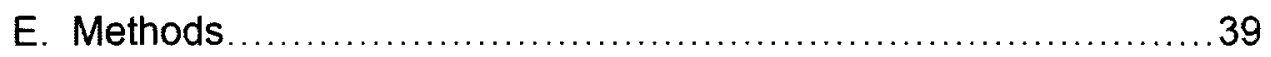

i. Study Subjects ........................................... 39

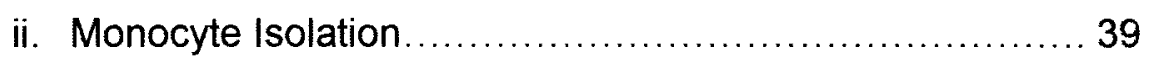

iii. Phosflow Pathway Analysis................................ 41

iv. RNA Isolation ............................................. 42

v. Cytokine Measurements....................................... 45

vi. MicroRNA and MessengerRNA Expression.............. 45

vii. MicroRNA-Transfection ..................................... 47

viii. IL-10 Addition / Anti-IL-10 Receptor Blockade .............. 48

ix. Statistical Analysis .............................................. 49

IV. EFFECT OF TEMPERATURE ON CYTOKINE EXPRESSION ........51

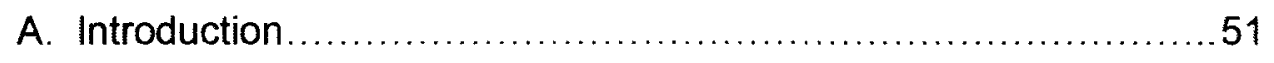

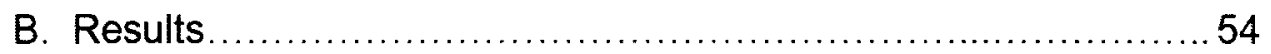

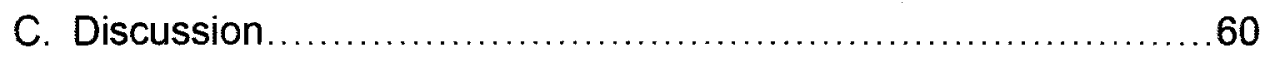


V. ANALYSIS OF THE NF-KB AND MAPK SIGNALING PATHWAYS AT

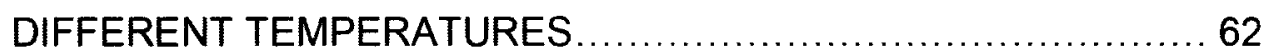
A. Introduction 62
B. Results. 64
C. Discussion 69

VI. INFLUENCE OF TEMPERATURE ON EXPRESSON OF CYTOKINE

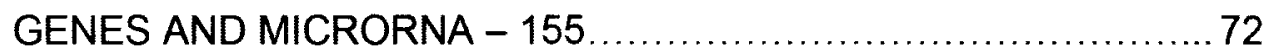
A. Introduction .72
B. Results. 73
C. Discussion 79

VII. MiRNA-155 IS RESPONSIBLE FOR THE PROLONGED TNF- $\alpha$

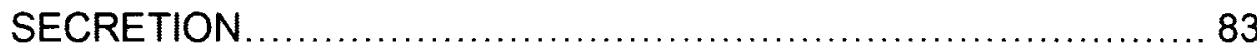
A. Introduction 83
B. Results 85
C. Discussion 93

VIII. IL-10 SUPPRESSES MIRNA-155 AND IS AN IMPORTANT NEGATIVE FEEDBACK LOOP ........................................96
A. Introduction 96

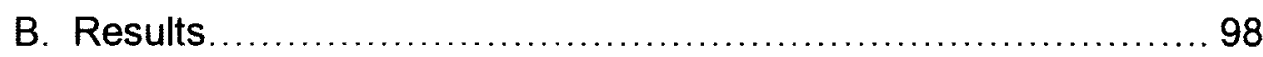

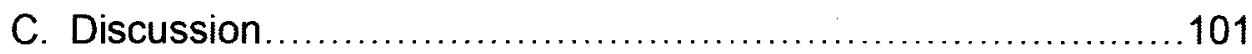

IX. CONCLUSIONS AND OVERVIEW ................................... 105

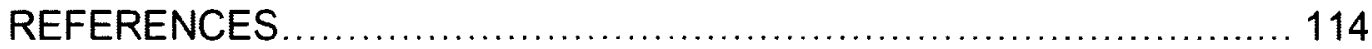

APPENDIX: ABBREVIATIONS ............................................. 132 


\section{LIST OF TABLES}

TABLE

PAGE

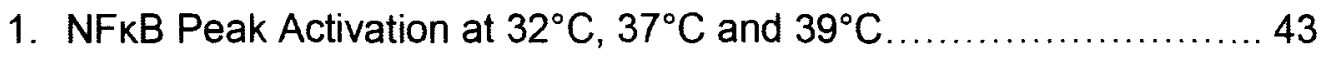




\section{LIST OF FIGURES}

FIGURE

PAGE

1. Overview of the Inflammatory Response ...............................14

2. Overview of the Inflammatory Signaling Pathways .................... 22

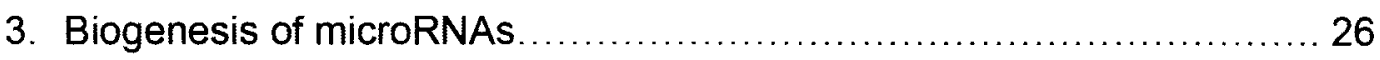

4. MicroRNAs involved in the Toll-like Receptor Signaling Pathway ........ 27

5. Action of miRNA-155 and -101 in the TLR-4 Pathway ...................28

6. Research Plan and Investigated Steps of the Monocyte Response...... 38

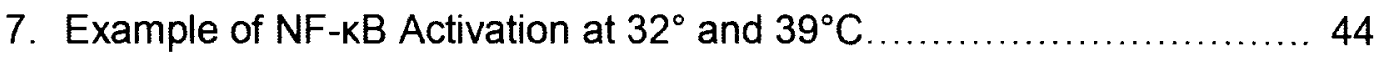

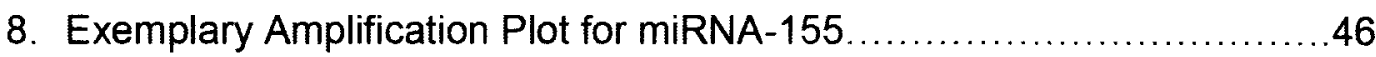

9. Effect of Different Amounts of Anti-IL-10 Receptor Antibody on TNF-a and

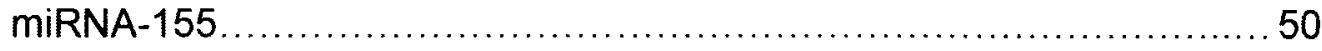

10. Flow Scatter Plot of Freshly Isolated Monocytes and 36h after LPS

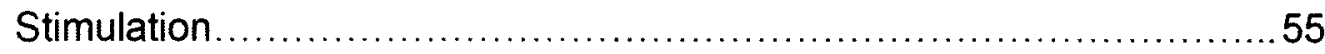

11. TNF-a, IL-6 and IL-10 Over $36 \mathrm{~h}$ at $32^{\circ} \mathrm{C}$ and $39^{\circ} \mathrm{C} \ldots \ldots \ldots \ldots \ldots \ldots \ldots . \ldots . \ldots . \ldots . \ldots$

12.Activation of the Activation of the NF-KB, p38 and JNK .................66 66

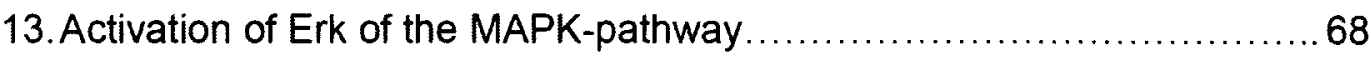

14. Expression of TNF- $\alpha$ and IL-10 mRNA at $32^{\circ} \mathrm{C}$ and $39^{\circ} \mathrm{C} \ldots \ldots \ldots \ldots \ldots . .76$

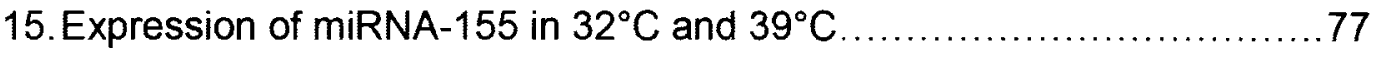

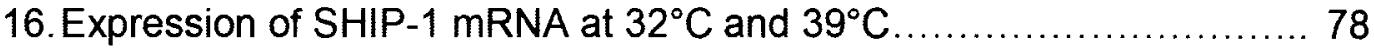


17. The Increased and Prolonged miRNA-155 Expression Contributes to the Prolonged and Increased TNF- $\alpha$-Production ............................. 82

18. Over-expression and Suppression of miRNA-155 .................... 88

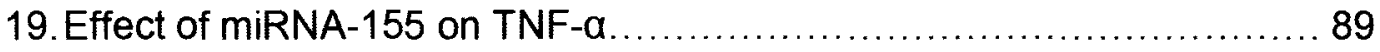

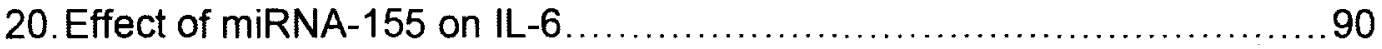

21. Effect of miRNA-155 on IL-10 ...................................... 91

22. Effect of miRNA-155 on SHIP-1 mRNA .............................. 92

23. Effect of Additional IL-10 in TNF- $\alpha$ and miRNA-155 at $32^{\circ} \mathrm{C} \ldots \ldots \ldots \ldots . . . . .99$

24. Effect of IL-10 Receptor Blockade on TNF- $\alpha$ and miRNA-155 at $39^{\circ} \mathrm{C} \ldots 100$

25.Proposed Role of IL-10 in Suppression of miRNA-155 Expression and

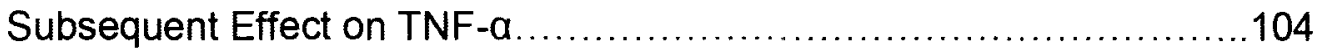

26. Summary of Our Results............................................ 113 


\section{CHAPTER 1}

\section{GENERAL INTRODUCTION}

Hypothermia is a strong independent predictor of complications and mortality in surgical patients (1-10). Hypothermic trauma patients are at an especially high risk for death $(1,4-6,8,9)$. In severely injured patients, hypothermia very often occurs together with acidosis and coagulopathy in patients with hemorrhagic shock, the so-called "triad of death". The detrimental effects of hypothermia have also been described in elective surgery with increased rates of surgical site infections and increased blood loss $(2,3,7,11)$.Therefore, prevention of hypothermia, but especially aggressive rewarming in already hypothermic patients are important steps during every surgical procedure and an integral part of the care of the injured patient (12-14).

The reason for the increased rate of surgical site infection and multiple organ dysfunction (MODS) in hypothermic patients is largely unclear. Early work demonstrated decreased formation of Reactive Oxygen Species (ROS) in phagocytes of hypothermic patients. These results have been reproduced in cooled blood of healthy volunteers $(15,16)$. Other investigators found impaired dendritic cell function in hypothermia, a cell with a pivotal role in the initiation of the immune response (17). Differences in pro- and anti-inflammatory cytokine 
production between hypo- and normothermic conditions have been reported by several groups, although some of these results are contradictory (18-22).

As of yet, the intracellular mechanisms leading to these observed differences in cytokine production and cell function have not been thoroughly investigated. It has been shown that hypothermia affects activation of central inflammatory signaling pathways and that the gene expression of monocytic cell lines, when were exposed to hypothermia, are profoundly dysregulated $(19,23-$ 25). The interactions of the different activation of signaling pathways, gene expression and other regulators of cell function such as microRNAs have not been investigated.

The purpose of this work is to investigate which mechanisms lead to the observed differences in cytokine secretion, in order to understand the regulation of the monocyte immune response and, identify areas for potential therapeutic interventions that may restore monocyte function. 


\section{CHAPTER II}

\section{BACKGROUND}

\section{CLINICLAL IMPORTANCE OF HYPOTHERMIA}

The care of the surgical patient has progressed significantly over the last century. The mortality of elective colon resection continuously decreased from above $30 \%$ in 1914 to $1.5 \%$ currently $(26,27)$. The reasons for this development are manifold. The introduction of blood banks in the 1940's allowed surgeons to operate on more patients and reduced the immediate post-operative mortality (26). Prophylactic antibiotics use decreased surgical site infections (SSI) subsequently reducing postoperative morbidity and mortality (28). Several decades later, among many other interventions, adequate blood glucose control was found to further reduce morbidity and mortality in surgical patients (29).

In order to assure safe and high quality surgical care throughout the United States of America, the Surgical Care Improvement Project (SCIP) was started with the goal of reducing complications and mortality of surgical patients. Practice guidelines based on clinical trials were issued, which aim to improve surgical safety and outcome. SCIP includes one process measure to reduce cardiac complications, two process measures with regard to venous 
thromboembolism prophylaxis and seven process measures, which aim to reduce surgical site

infection. Three of these seven measures deal with the appropriate choice, timely administration and discontinuation of antibiotics within 24 hours post operatively. The next three measures recommend appropriate hair removal, blood glucose control and early removal of urinary catheters. The last SCIP measure aiming to reduce surgical site infection is prevention of hypothermia. In contrast to hypothermia, fever is believed to be beneficial for host defense. Kluger demonstrated that fever is protective and that infected, ectothermic animals increase their body temperature by exposing themselves to higher environmental temperatures $(30)$.

Hypothermia has been shown to increase wound infections in several studies. The early work of Kurz et al. in 1996 demonstrated in a prospective and randomized study that prevention of hypothermia reduces surgical site infections (7). Besides reduction in wound infections, the authors also found a significantly shorter time to food intake and a shortened length of hospital stay. These results were confirmed by other groups. Flores-Maldonado found a six-fold increased risk for wound infections in patients who became hypothermic during an elective cholecystectomy (31). Seamon et al. also found increased wound infections in trauma patients who became hypothermic during the initial operations, but were not hypothermic at admission (4). In non-abdominal operations, hypothermia was also found to increase blood loss and post-operative complications (32). Taking these results a step further, Melling et al. demonstrated that warming of the site 
of the surgical incision or the whole patient before the operation, is able to reduce the rate of surgical site infections (33).

Other studies challenged these results. Barone et al: could not find an association between intraoperative hypothermia and wound infection in a retrospective chart review (34). Lehtinen et al. and Smith et al. found no impact of hypothermia on wound infection $(35,36)$. Walz et al. even found a decrease in wound infection in hypothermic patients, although the body temperature difference was clinically not significant between the two groups (37).

In addition to the effect on the rate of operative wound infections, hypothermia has also been associated with increased mortality. The main body of this evidence originates from the trauma literature. Several publications found a highly significant association between admission temperature and death $(1,5,8-$ $10,14)$. Beilman et al. found increased rates of organ failure but no impact on mortality in hypothermic trauma patients (6). Two recent studies challenge the direct effect of hypothermia on mortality. The authors of these studies propose that hypothermia is a marker for severely injured patients rather than the cause for the increased mortality $(38,39)$. Of note, Mahid et al. found that hypothermia in elective surgical patients is associated with a four-fold increase in mortality (2). Importantly, the cause of death in hypothermic patient is not necessarily related to infectious complications. Frank et al. found a significant increase in cardiac morbidity in elective surgical patients with perioperative hypothermia (40). 
In septic patients, the development of hypothermia is very detrimental or at least a sign of failing host defenses. Septic patients, which present with or develop hypothermia, have a two-fold increase in mortality compared to febrile septic patients (41-44). Furthermore, a very recent study proposes that the use of anti-pyretic agents in septic patients may be detrimental and should be avoided (45). These results suggest that fever has a beneficial effect on the host defense and the lack of fever, especially when hypothermia develops, is a marker of the failure of host defense.

In summary, the majority of the available literature demonstrates that hypothermia has detrimental effects on outcomes in both surgical and medical patients. In surgical patients, hypothermia often occurs during or even before the operation and subsequently leads to increased rates of complications and death. In medical patients with sepsis, hypothermia is more a consequence of a failure of the immune system to mount an appropriate response and, consequently, is strongly associated with death in these patients.

The mechanisms by which the body temperature is regulated and the roles of cytokines in this process are very complex and not very well understood. Interleukin-1 (IL-1) and IL-6 have mainly pro-pyretic functions, whereas Tumor Necrosis Factor- $\alpha$ (TNF- $\alpha$ ) is believed to induce hypothermia (46). The organization of the immune response, the involved cells, their secreted cytokines as well as the impact of hypothermia on these processes will be discussed next. 


\section{OVERVIEW OF THE IMMUNE RESPONSE}

The purpose of the immune system is to defend the host against invading pathogens such as bacteria, fungi, and viruses. It is also responsible for removal and clearing of dead cells and plays an important role in inducing repair mechanisms after injury (47). While executing all these tasks, the immune system must not attack healthy host cells and the development of autoimmunity must be avoided. For this purpose, the immune system evolved in two different systems, which are separated into the innate system, which is considered the older of these two systems, and the adaptive system. The innate system is the primary defense and reacts immediately, but not specific to any kind of trauma or infection with a reproducible response. This type of immune response can be found in all vertebrates as well as some plants, fungi and primitive multicellular organisms (47). The adaptive system mounts a much slower response, it takes several days to react, but is much more specific and targeted than the innate system. Once the adaptive system has been exposed to a certain pathogen, the second exposure to this same pathogen results in an immediate, stronger response, often preventing the actual infection. However, these two systems cannot be separated as clearly as described here and there are multiple important interactions between cells of both systems. In fact, the adaptive system relies on activation signals from the innate system. We focus our studies on the monocyte/macrophage, a cell of the innate immune system, which is the principle activator of the adaptive system. 
The innate immune system consists of two major components: passive defense mechanisms such as epithelial barrier, mucous fluids and secreted proteins, which inhibit the growth of pathogens. The second and active defense system consists of several different types of immune cells. The largest numbers of these innate immune cells are granulocytes of which the majority are neutrophil granulocytes (neutrophils). The main role of these neutrophils is the phagocytosis and destruction of pathogens, mainly bacteria and fungi. The eosinophil granulocytes are involved in the destruction of parasites, whereas the role of the basophil neutrophils is not very clear. Mast cells are found in tissues and the abdominal cavity. These cells are loaded with vesicles filled with histamine and other vasoactive and immune-active substances, which can be released via an antibody-dependent pathway or by direct activation of the mast cell. Mast cells have been implicated in development of hypothermia in endotoxemic shock (48).

\section{Monocytes, Macrophages, Dendritic Cells and Their Relationship}

Monocytes, macrophages and dendritic cells are important cells of the innate immune system. These three cell types are related: the macrophages and dendritic cells originate from the monocytes, which is the precursor found in blood and bone marrow $(49,50)$. Macrophages and dendritic cells are found in all tissues. Tissue macrophages have different names based on the tissue they were first described such as Kupffer cells for the liver or Langerhans cell for the 
skin because they were described in histologic preparations before their role and common origin had been elucidated. Macrophages and dendritic cells patrol the tissue in order to detect invading pathogens, but also to remove necrotic cell debris. After tissue injury or the detection of pathogens, macrophages release a host of cytokines and chemokines leading to the attraction of neutrophils and other immune cells, which act to eliminate the infection and repair of the tissue injury (51). Macrophages and especially dendritic cells have another, very important role which is to induce the adaptive immune response. Macrophages present antigens with the Major Histocompatibility Complex II (MHC II) from the phagocytized pathogen to $T$ - and B-cells of the adaptive system resulting in the induction of the adaptive immune response. This function of antigen-presentation is an essential role of these cells. One of the major MHC II receptors is HLA-DR (Human Leukocyte Antigen-DR). Expression of HLA-DR on monocytes has been demonstrated to be a reliable marker for outcome after trauma and burns (5259). Low expression of HLA-DR and especially the lack of up-regulation of HLADR after ex-vivo stimulation with LPS, correlates with increased complications and death. The restoration of the antigen presenting capability of peripheral blood monocytes can be achieved by administration of immune-modulatory drugs such as Interferon-y (IFN-y) or the Granulocyte-macrophage colony-stimulating factor (GM-CSF) $(56,57,60,61)$. However, thus far a clinically relevant improvement in survival rates parallel with increased HLA-DR expression has not been demonstrated. Hypothermia reduced HLA-DR expression whereas fever increases HLA-DR $(62,63)$. 
At least two different subtypes of peripheral blood monocytes have been described. The "classical" monocyte expresses a high level of CD14, an essential surface receptor for recognition of LPS, a medium level of HLA-DR and no CD16 (CD14++HLA-DR+CD16-) $(49,64-67)$. Over $80 \%$ of the peripheral blood monocytes are "classical" monocytes; the remaining are so-called "inflammatory" monocytes. In addition, an intermediate between the "classic" and "inflammatory" monocyte may exist. The "inflammatory" monocyte expresses a low level of CD14 but high levels of HLA-DR and CD16 (CD14+HLA-DR++CD16+). These "inflammatory" monocytes produce high levels of TNF- $\alpha$, but low or no IL-10 $(64,67,68)$. In addition, stimulation of T-cells is stronger and more efficient. In inflammatory states, a shift to a higher percentage of "inflammatory" monocytes can be observed $(64,69)$. It is currently believed that these "inflammatory" monocytes develop into strongly pro-inflammatory dendritic cells, the so-called "tip-DCs" $(50,70)$. In addition to the differences in cytokine secretion, "inflammatory" monocytes $\left(\mathrm{CD} 16^{+}\right)$are able to leave but also re-enter the blood stream or lymphoid tissue, whereas "classic" monocytes are only able to leave the blood stream but cannot re-enter $(50,65,67,70,71)$. These "classical" monocytes replenish the pool of tissue macrophages and support the tissue macrophages during infections.

In summary, monocytes are the precursor of the macrophages and dendritic cells and play an important role in the immune response. Clinical evidence suggests that the dysfunction of the monocyte/macrophage systems is a major contributor for infectious complications such as sepsis. We and others 
believe that hypothermia affects the monocyte function, as indicated by reduced HLA-DR expression and changes in cytokine secretion, and this impaired function contributes to the higher risk of infectious complications in hypothermic patients (17).

\section{Sequence of the Immune Response}

An outline of the initial phase of the immune response and the role of the monocyte/macrophage is shown in Figure 1. An infection with bacteria leads to activation of monocytes or macrophages by two routes. Monocytes recognize pathogen associated molecular patterns (PAMPs) such as components of cell walls of bacteria such as Lipopolysaccharide (LPS) from gram-negative bacteria or Lipoteichoic-acid from gram-positive bacteria (72). In addition, the infection leads also to tissue destruction, which results in the release of endogenous proteins from these cells such as heat shock proteins (HSP) or the High-Mobility Group Protein B1 (HMGB1), which are referred to as alarmins (73-76). PAMPs and alarmins together are referred to as danger associated molecular patterns (DAMPs) $(77,78)$. The bacterial components as well as the endogenous proteins are recognized by a variety of receptors on monocytes. These receptors recognizing certain distinct patterns of pathogens are termed Pathogen Recognition Receptors (PRR's). The activation of these PRR's results in the activation of intracellular signaling pathways and subsequent secretion of cytokines and chemokines $(51,79,80)$. The cytokines activate other immune cells 
in the same tissue but also in the whole body if they are released systemically. Furthermore, cytokines such as TNF- $\alpha$, IL- 6 and II-1 $\beta$ are responsible for the systemic effects of an infection such as fever, increased cardiac output, vasodilatation and the release of more immune cells from the bone marrow (72). The chemokines attract other immune cells to the site of infection. The main incoming cells are neutrophils, which phagocytize and destroy the pathogens. After clearance of the bacteria, lipid-mediators such as Protectins and Resolvins are secreted attracting more monocytes/macrophages to the site of infection. These lipid mediators increase the phagocytic activity of the monocytes/macrophages without stimulating the release of pro-inflammatory cytokines (resolution of inflammation) $(81,82)$. The non-inflammatory macrophages remove the debris and remainders of the apoptotic or necrotic neutrophils. Furthermore, tissue repair is stimulated and fibroblasts induce the healing of the wound and usually form a scar which matures over time.

\section{Role of Cytokines in the Immune Response}

The secreted cytokines serve as messengers of the immune system and coordinate the local response by attraction of different leukocyte subtypes, as well as by inducing a whole body response, which aims to prepare the host to fight the infection in the best possible way (83-86). The attraction of additional leukocytes is supported by the local secretion of chemokines. Leukocytes follow a gradient of chemokines to the site of infection and are activated by cytokines in 
the same environment. In addition, the cytokines activate the endothelium of the local vasculature, which leads to the expression of several adhesion molecules, facilitating the extravasation of the leukocytes at the site of infection and increasing the capillary permeability (87). The increased capillary permeability allows also the extravasation of complement proteins and coagulation factors, which support the cellular defense by opsonizing bacteria. Moreover, cytokines also have vasodilatating effects resulting in an overall local increase in blood flow, but also to decrease in flow speed in each vessel, which again facilitates attachment and extravasation of leukocytes. Another result of the endothelium activation is the activation of the coagulation cascade, which leads to clotting of some of the outflowing vessels and therefore helps containing the infection locally (88). Clinically, these local changes can be appreciated by swelling (tumor), redness (rubor), heat (calor) and pain (dolor).

Besides these very important local effects, cytokines induce systemic effects known as the acute phase response $(83,84,89,90)$. The acute phase response consists of fever, increased permeability of the vasculature, changes in metabolism and the increased or decreased production of certain proteins by the liver. The main effectors of the acute phase response are TNF- $\alpha, \mathrm{IL}-1 \beta$, and IL- 6 .

In summary, the secretion of these pro-inflammatory cytokines, TNF- $\alpha$, IL$1 \beta$ and IL-6 is the first and very important step of the monocytes response. These cytokines then trigger a cascade of events, which optimize the local host defense but also prepare the rest of the body to support the host defense process. Consequently, an increased or reduced secretion of these cytokines can have 
Figure 1: Overview of the Inflammatory Response

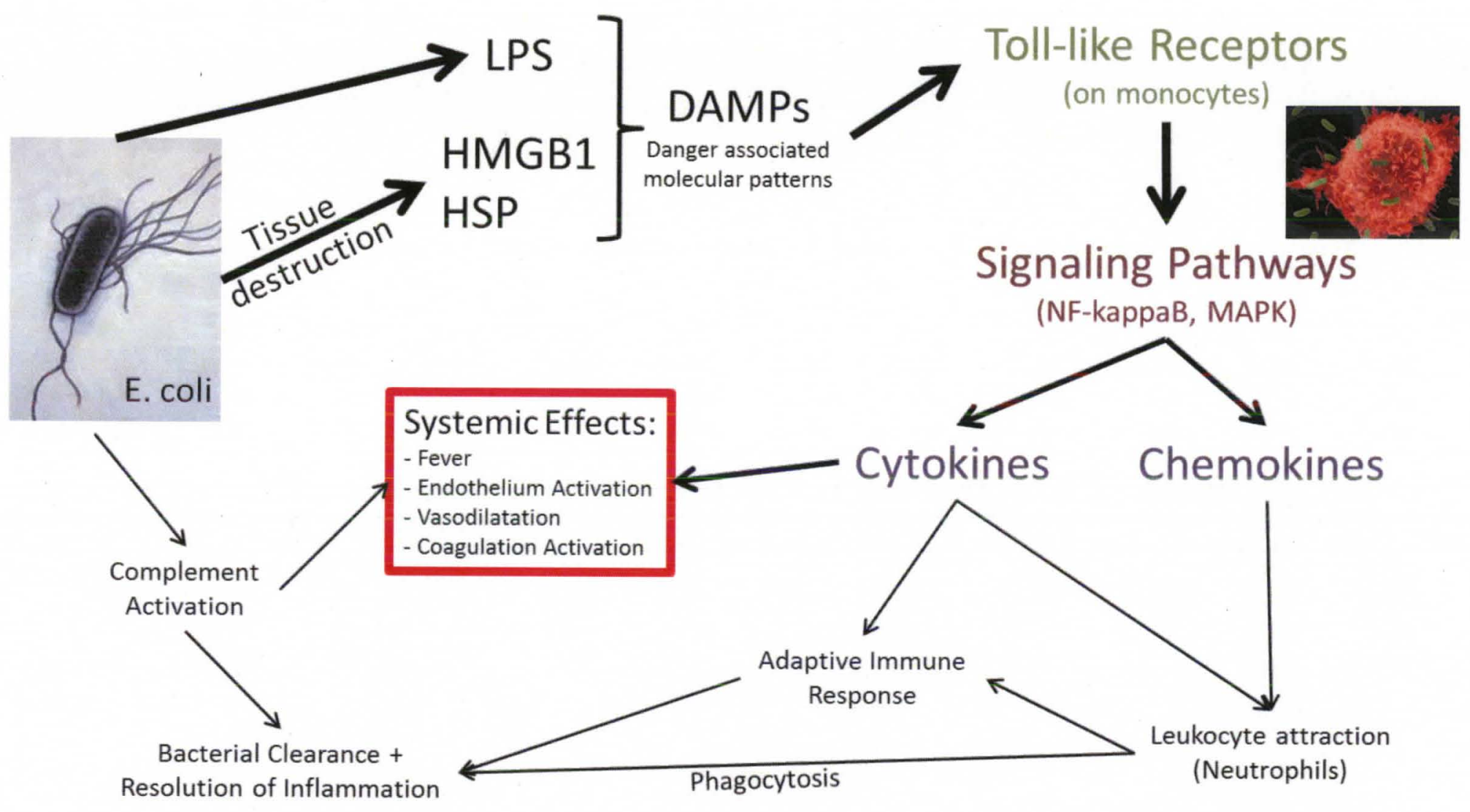




\section{Legend to Figure 1}

Infection with a pathogen (E. coli) is recognized by monocytes/macrophages. Activation of monocytes and macrophages result in the secretion of pro-inflammatory cytokines. These cytokines attract other immune cells such as Neutrophils to the site of infection but also initiate a systemic whole body response with fever and other effects which support the defense of the host. After phagocytosis of the pathogens and their clearance, the resolution of the inflammation is initiated by secretion of lipid mediators such as Resolvins and Protectins. These mediators attract noninflammatory macrophages, which phagocytize necrotic Neutrophils without secretion of pro-inflammatory cytokines. At the same time tissue repair mechanisms are initiated. 
detrimental effects to the host. Over-expression of TNF-a results in a lethal shock, whereas an inadequately weak immune response is also detrimental (9196).

Monocytes and macrophages produce also IL-10. IL-10 is a cytokine with anti-inflammatory properties, which has in general opposing effects to the proinflammatory cytokines (97-100). It suppresses the further secretion of the proinflammatory cytokines by inhibiting their production in monocytes and macrophages. This property of IL-10 led to the original name of IL-10: human cytokine synthesis inhibitory factor. The strong anti-inflammatory properties of IL10 have been demonstrated in models of lethal endotoximic shock, which result in an exaggerated secretion of pro-inflammatory cytokines, mainly TNF- $\alpha$. In these models, injection of IL-10 reversed the shock symptoms and increased the survival of the animals. An appropriate anti-inflammatory response is an important step to limit systemic and local inflammation and prevent excessive damage to the host organism.

These data reveal a tightly regulated and ordinarily balanced system of pro- and anti-inflammatory mediators. The balanced secretion of first proinflammatory followed by anti-inflammatory mediators is believed to be the key for an adequate host defense. Inadequate secretion of pro-inflammatory cytokines can result in lethal shock $(75,91)$. Blockade of these cytokines can increase survival $(93,97,98,101)$. However, an inappropriate suppression of the immune system makes the host susceptible to over-whelming systemic infections $(94-96,102,103)$. Unfortunately, neither reduction of the pro-inflammatory 
response nor stimulation of the immune system were successful in clinical trials $(56,57,61,104-107)$. In retrospect, many of these substances were crude sledgehammers and the test situations clinically unlikely to respond significantly to a single addition to an array of therapies already in place. Changes in this tightly controlled system have profound consequences on the immune response and therefore survival of the host. In our research, we focus on the role of the monocyte/macrophage in the initiation of the immune response. We believe that hypothermia results in dysfunction of the monocyte cytokine secretion and thereby impairs the host defense.

\section{ROLE AND REGULATION OF THE MONOCYTE}

The principle role of monocytes is the recognition of pathogens, initiation of the immune response and presentation of antigens from phagocytized pathogens to cells of the adaptive immune system $(51,72,79)$. The secretion of pro-inflammatory cytokines is the cornerstone of the initiation of the immune response. Besides these pro-inflammatory cytokines, monocytes produce also IL-10, which is an inhibitory cytokine and limits the immune response in order to prevent excessive damage to the host. The secretion of pro- and antiinflammatory cytokines is tightly controlled on several levels with negative feedback loops within the cell as well as from outside the monocyte. 


\section{Pathogen Recognition and Intracellular Signaling}

The first step in the immune response is the recognition of the pathogen $(72,79,80)$. For this purpose, monocytes are equipped with a variety of extra- and intracellular PRR's of which Toll-Like Receptor 4 (TLR-4) is one of the best described. TLR-4 can recognize LPS but also several endogenous proteins such as heat shock proteins and HMGB1 $(79,108-110)$. Besides TLR-4, at least twelve other Toll-like receptors have been described. Some of these Toll-like receptors are localized within the cell in phagosomes and allow recognition of phagocytized pathogens. Other extracellular receptors are the Receptor for Advanced Glycation Endproducts (RAGE), which recognizes endogenous proteins and glycated proteins, which occur in poorly controlled diabetic patients. The Scavenger receptor is another extracellular receptor, which recognizes mainly bacterial products but also oxidized lipoproteins. This receptor is believed to contribute to the formation of arterial plaques (111). Another large group of PRR's are the Nucleotide Oligomerization Domain receptors (NOD-like receptors) (112-114). These receptors are mainly located intracellularly. Intracellular receptors often respond to bacterial or viral RNA and DNA fragments which are released from digested bacteria or viruses, which infect the cell. The detection of bacterial RNA is believed to be an important assessment point for the immune system in order to determine the virulence of the infection (115). Detection of bacterial RNA indicates the presence of viable, growing bacteria and results in a more vicious and prolonged inflammatory response compared with stimulation with LPS alone. 
LPS is bound by the LPS-binding protein, which in turn binds the CD14 surface receptor on monocytes (116). The complex of CD14, LPS and LPSbinding protein associates with TLR-4, resulting in the activation of the TLR-4 signaling cascade. TLR-4 may interact with several down-stream signaling proteins. However, the seemingly most important signaling protein is Myeloid differentiation primary response gene 88 (MyD88), which in turn interacts with the Interleukin-1 Receptor Associated Kinase 1 and 2 (IRAK 1 and 2) $(108,117)$. IRAK 1 and 2 activate then the TNF-Receptor Associated Factor 6 (TRAF 6), which is able to activate two central, stress response pathways, the Nuclear Factor K Beta (NF-KB) and the Mitogen Activated Protein Kinase Pathway (MAPK). After activation of the TLR-4 signaling pathway, inhibitory proteins are expressed and inactivate the TLR-4 pathway by targeting the central complex consisting of IRAK $1 / 2$, and TRAF-6. These inhibitory proteins are phosphatases, which cleave off the activating phosphate on these proteins. Two of these upstream inhibitors are the Suppressor of Cytokine Signaling 1 (SOCS-1) and the SH2 domain-containing inositol 5'-phosphatase 1 (SHIP-1) (118-120).

\section{NF-KB and MAPK-Pathway in the Monocyte Response}

Intracellular signaling pathways are crucial to the capability of cells to cope with changes in their environment, process and integrate incoming signals from several receptors and to respond in an appropriate manner (121-124). Two pathways are essential for the monocyte response: the NF-KB and MAPK- 
pathway. Both are activated by a variety of surface and intracellular receptors. Importantly, there is a broad cross-activation between the NF-KB and the MAPKpathway. An outline of these two pathways is shown in Figure 2.

The activation of TRAF 6 by IRAK 1 or 2 results in the activation of the Inhibitory K-Kinase (IKK), of which three subtypes, exist. IKK then phosphorylates the Inhibitory k protein Beta (IKB), which is bound to the NF-KB complex consisting of the p65 and p50 subunit. The complex of p65/p50 and lkB is localized in the cytoplasm of the monocyte. Phosphorylation of IkB results in its degradation and the release of the p65/p50 complex $(109,123-125)$. The NF-KB complex is now able to migrate into the nucleus and binds promoter sites of cytokine genes and other stress response genes resulting in their transcription. The inactivation of NF-KB occurs by constitutional re-expression of IkB, which binds the p65/p50 subunit resulting in its inactivation. The importance of this activation mechanism is that NF-KB itself is a transcription factor and does not depend on the activation of other transcription factors or their production.

The MAPK-pathway is also activated by TRAF 6 . In contrast to the NF-KB pathway, the MAPK-pathway is organized in three arms and several levels of protein kinases. The three arms are $p 38$, the extracellular signal-regulated kinases (Erk 1 and 2), and the C-Jun N-terminal kinases (JNK 1-3). These three arms can induce expression of a variety of similar or closely related genes such as pro-inflammatory cytokines $(109,121,122,126)$. However, the Erk-pathway seems to hold a pivotal role in the induction of the IL-10 production, whereas the p38 and JNK-arm appear not to be mandatory for IL-10 production (99). Over- 
simplified, the p38 and JNK-arms have mainly pro- inflammatory properties, whereas the Erk-arm also has anti-inflammatory properties, mainly by induction of IL-10 expression.

The MAPK-pathway is organized in several layers, in which the top layer activates the subsequent level, which in turn activates the next level. There are a total of at least three levels, MAPK1 -3 in which MAPK3 is the first level of activation and MAPK1 is the level of $p 38$, Erk 1/2, and JNK1-3. TRAF 6 activates the MAPK3 level by phosphorylation. The MAPK1 proteins, i.e. p38, Erk and JNK, phosphorylate transcription factors such as the Activated Transcription Factor 1 (ATF1), C-Jun or C-Fos. The purpose of organization in to these several levels is that an incoming signal can be amplified resulting in a strong, reliable activation of the down-stream targets. In contrast to the NF-KB-pathway, the inactivation of the MAPK-pathway is an active process, which is tightly regulated and may result in selective inhibition of a certain arm of the MAPK-pathway. The inactivation occurs mainly on the MAPK 1 level by specific so-called Dual Specificity Phosphatases (DUSP's) or MAPK-phosphatases (MKP's) (127-130). Most of these DUSP's are specific for one or two of the three arms of the MAPKpathway. DUSP 1 for example inactivates the p38 and JNK arm but not the Erk arm. This organization offers the opportunity to fine tune the activation of each of the three arms. There are at least 30 proteins described, which contain the typical phosphatase domain. However, only eleven of these also contain the MAPK-binding site. The physiologic role of these DUSP's without MAPK-binding 
Figure 2: Overview of the Inflammatory Signaling Pathways

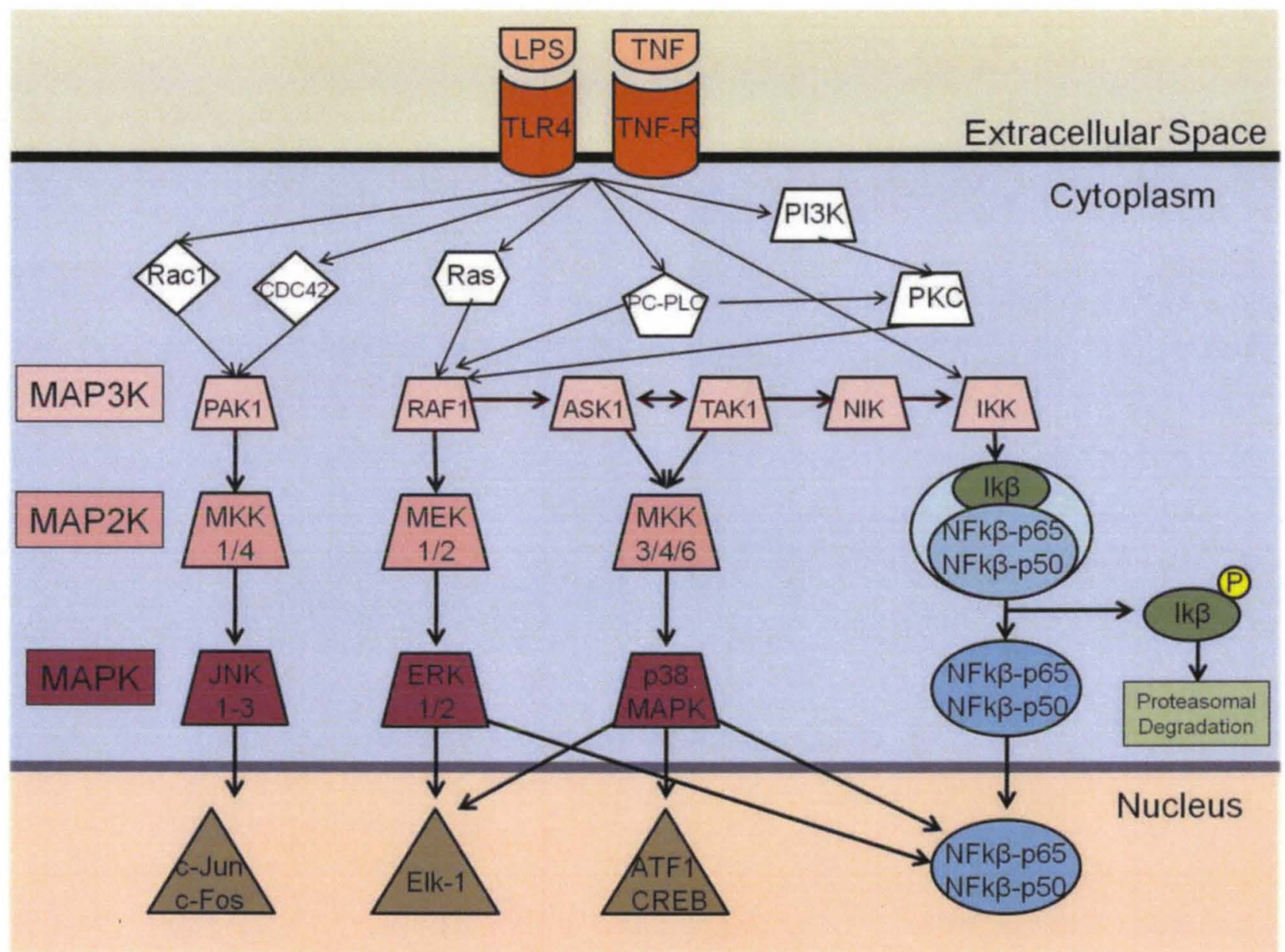




\section{Legend Figure 2}

The NF-KB and Mitogen-Activated Protein Kinases Pathway (MAPK) are intracellular signaling pathways which are activated by stress signals and induce a stress response. TLR-4 recognizes LPS and activates a cascade of signaling proteins, which results in activation of NF-KB and MAPK. The key activator of NF-KB is the Inhibitory K Kinase (IKK), which phosphorylates the Inhibitory $k$ Protein $\beta$ resulting in its degradation. The NF-kB complex consisting of the $p 65$ and p50 subunit translocates into the nucleus and activates gene transcription.

The MAPK-pathway is activated by a variety of proteins. This pathway consists of three arms, JNK, Erk and p38. There are several layers of kinases, which are activated subsequently starting at the MAPK3K level. This arrangement leads to an amplification of the incoming signal. JNK, Erk and p38 activate several transcription factors, which then induce transcription of the target genes.

There is a very high degree of redundancy in activation of these pathways. 
domain is unclear. It appears also that there is a certain tissue specificity of the DUSP's and only a few of them are expressed in all tissues and cell types.

These DUSP's are newly produced after activation of the MAPK-pathway within $30 \mathrm{~min}$ to 1 hour. The degree of up-regulation and also the subtype of the DUSP, which is up-regulated, can therefore lead to a modification of the MAPKpathway activation and shift the response of the cell. The result of activation of both, the NF-KB and MAPK pathway, is the production and secretion of cytokines as well as other proteins, for example heat shock proteins, which increase the resilience of the cell.

\section{MICRORNAS REGULATE THE MONOCYTE RESPONSE}

In the last few years, microRNAs have been recognized to be potent regulators of cell function (131-134). MicroRNAs are short, single-stranded RNA fragments with a length of $\sim 22$ nucleotides $(\mathrm{nt})$. The main role of microRNAs is the interference of protein production, mainly through a reduction in protein expression, although an increased protein production has been observed in starved cells (135).

The biogenesis of microRNAs is outlined in Figure 3. MicroRNAs are transcribed from DNA like normal genes. These pri-microRNAs are then processed by Drosha, an enzyme which cleaves RNA-stands, to pre-microRNAs. The pre-microRNA is transported into the cytoplasm by a specific transporter, Exportin-5. In the cytoplasm, the microRNA is processed by Dicer, a protein 
similar to Drosha but located in the cytoplasm, into the active, mature microRNA and is integrated into a protein complex, the RNA-induced silencing complex (RISC). Depending on the complementarity of the microRNA-seed sequence with the mRNA sequence, the mRNA is either degraded or the binding of the translation machinery inhibited. A 100\% complementarity of the microRNA seedsequence with the mRNA results in degradation of the microRNA, whereas an $80 \%$ match results in inhibition of the protein translation. Both processes result in reduced protein production. Importantly, a change in mRNA-levels is only evident when the mRNA is degraded. The catalytic active protein, which is able to degrade mRNA, is the Argonaut 2 protein (Ago2). As of yet, the main function of microRNAs in a broad sense appears to be the inhibition of protein production rather than degradation of the mRNA-strand.

\section{MicroRNAs Described in Monocytes}

Several microRNAs have been investigated and found to be important in the monocyte response (136-146). Figure 4 shows some of these microRNAs and their proposed targets. Among these microRNAs, miRNA-155, -146a, -101 , and -21 are among the best described. We will focus on microRNA-155 in our research. Depending on the target protein, the microRNAs can either have a proinflammatory or anti-inflammatory action $(139,140,145,147,148)$. MiRNA-155 and -101 both target inhibitors of the TLR-4 signaling pathway. Since microRNAs inhibit protein production, the inhibition of an inhibitor results in a prolonged 
Figure 3: Biogenesis of microRNAs

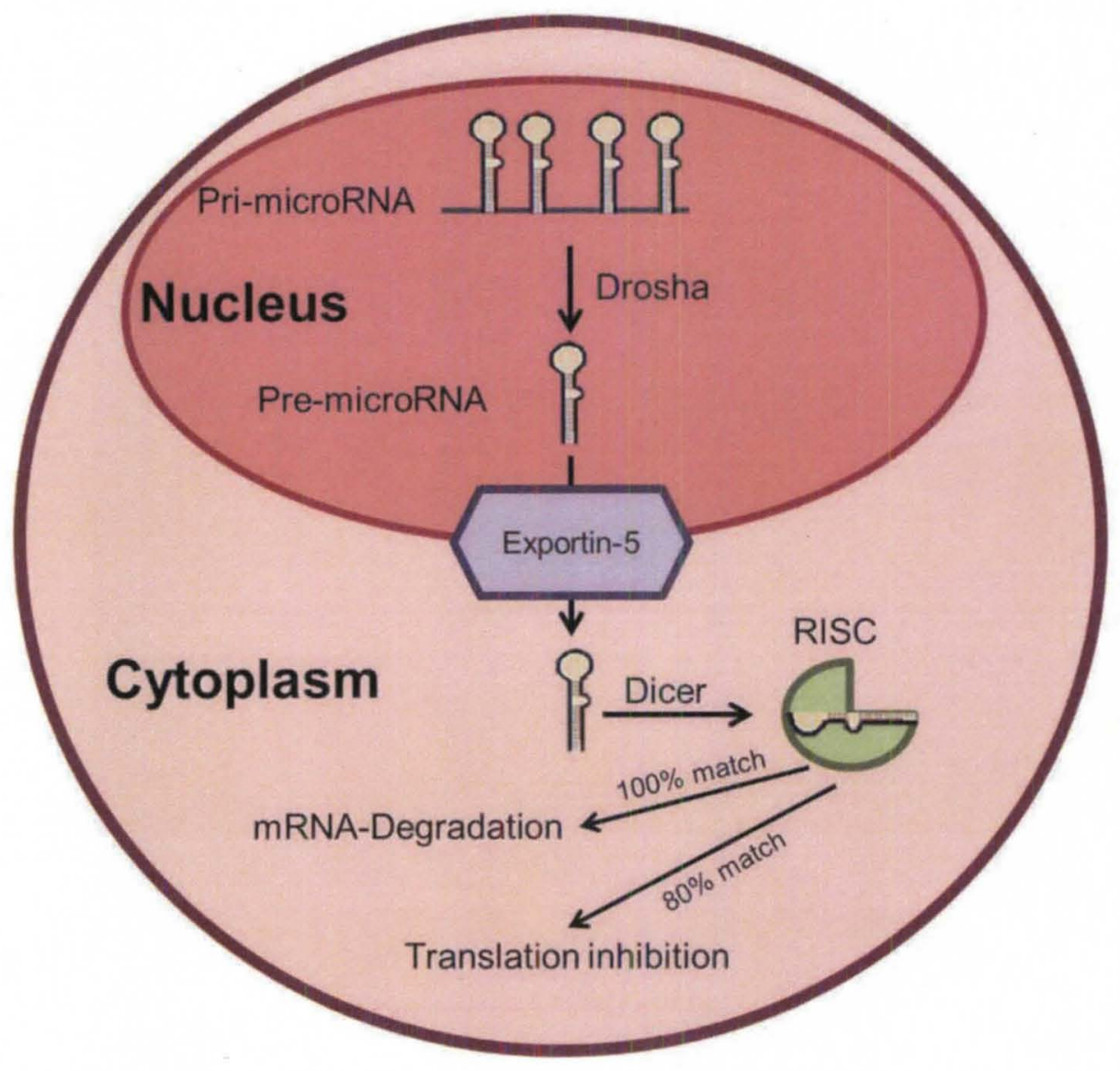

MicroRNAs are transcribed from DNA into pri-microRNA and are then processed by Drosha into the pre-microRNA. The pre-microRNA is transported into the cytoplasm by Exportin-5 and processed by Dicer and integrated into the RNAinduced silencing complex (RISC). The complementarity of the microRNA-seed sequence determines the effect on the target mRNA: a 100\% match results in the degradation of the mRNA whereas an $80 \%$ match inhibits protein production. Drosha and Dicer are RNA-processing enzyme located in the nucleus or cytoplasm, respectively. 
Figure 4: MicroRNAs involved in the Toll-like Receptor Signaling Pathway

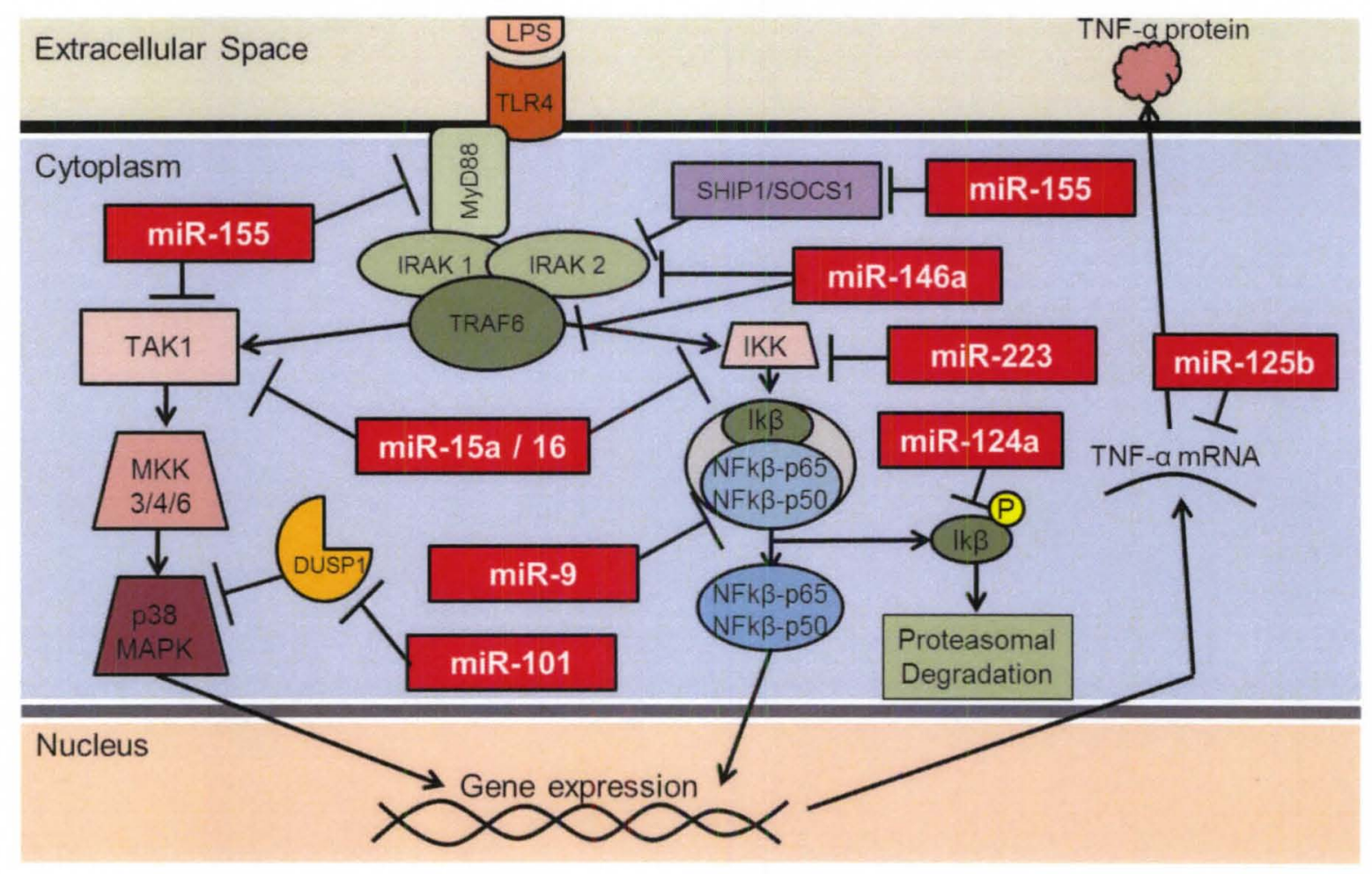

Several microRNAs target the TLR-4 pathway. Depending on the target, the microRNAs can either have pro- or anti-inflammatory properties. The fact that multiple microRNAs target several proteins on all levels of the TLR-4 pathway demonstrates a high redundancy and tight control of the activation of the pathway. Adapted and modified from $(137,139,144,146,149)$. 
Figure 5: Action of miRNA-155 and -101 in the TLR-4 Pathway

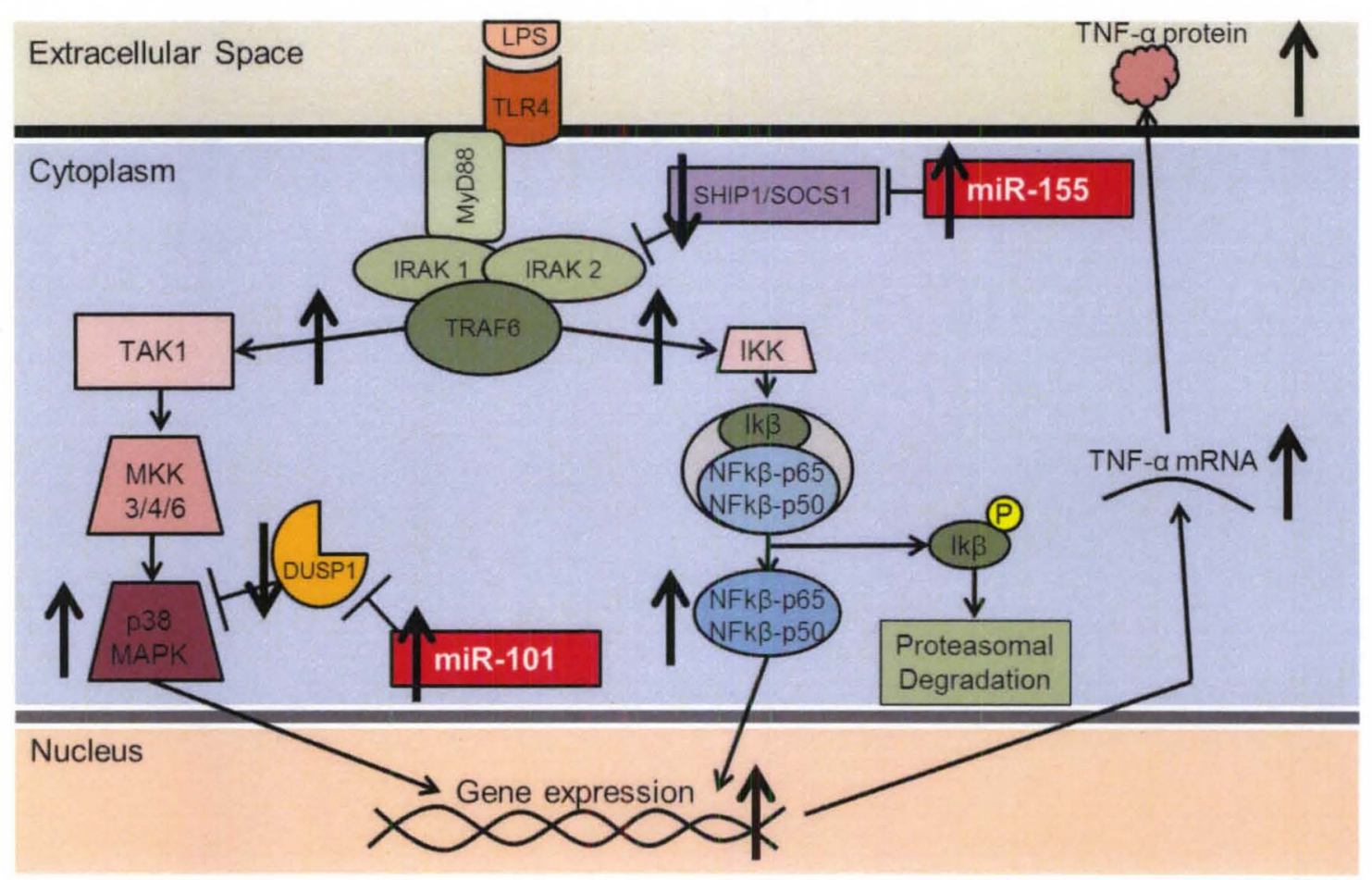

MiRNA-155 decreases production of SHIP-1/SOCS-1 and increases activation of both NF-KB and MAPK-pathway. MiRNA-101 reduces production of DUSP-1 increasing activation of $p 38$ and JNK. The synergistic action of these two microRNAs increases the production of pro-inflammatory cytokines. 
activation of the TLR-4 signaling pathway. MiRNA-155 targets SOCS-1 and SHIP-1 both are upstream inhibitors of the TLR-4 signaling pathway and inhibit IRAK-1/2 and TRAF-6 $(139,145,149)$. Up-regulation of miRNA-155 inhibits the expression of these inhibitors and results in a prolonged activation of the TLR-4 signaling prolonging the secretion of pro-inflammatory cytokines such as TNF- $\alpha$, IL-1 $\beta$ and IL-6 (Figure 5). Because SHIP-1/SOCS-1 are upstream inhibitors, only a slight reduction of their expression level can have profound impact on the activation of the NF-KB and MAPK-pathway. Besides the pro-inflammatory actions, miRNA-155 can also have anti-inflammatory actions. Suppression of MyD88 or TAB2 production by miRNA-155 results in a reduced signaling through the TLR-4 pathway and reduced secretion of TNF- $\alpha(140,148)$. The pro- or antiinflammatory effect of miRNA-155 is time-dependent and depends on the targeted protein and cell type. MiRNA-101 has pro-inflammatory properties (Figure 5). MiRNA-101 inhibits DUSP-1production prolonging the activation of the p38 and JNK-arm of the MAPK pathway, which also results in an increased secretion of TNF- $\alpha$ (146). Because miRNA-155 and -101 both target inhibitors of the same pathway, they have synergistic function.

In contrast to miRNA-155 and -101, miRNA-146a targets IRAK-1 and TRAF-6 to reduce the expression of these two proteins, resulting in a decrease in the TLR-4 signaling (Figure 4). Therefore, miRNA-146a has anti-inflammatory properties $(136,137,141,150,151)$.

MiRNA-21 is a very well described microRNA in cancer development because many of its targets are proteins of important signaling pathways (152- 
159). One of these target proteins is the Programmed Cell Death Protein 4 (PDCD-4). The exact function of PDCD-4 is unclear, but it has been proposed that it is involved in the induction of apoptosis. Therefore, up-regulation of miRNA-21 results in a decrease of PDCD-4 and consequently reduces apoptosis promoting cancer development. In the monocyte response, Sheedy et al. have proposed another regulatory loop (143). In this complex feedback loop, PDCD-4 inhibits the transcription of IL-10 mRNA. Up-regulation of miRNA-21 by activation of the TLR-4 signaling pathway results in a reduction of PDCD-4 expression and subsequently an increase of IL-10 mRNA, which then will be translated into IL-10 protein. The IL-10 protein will be secreted and acts as the above described inhibitor of the monocyte response.

\section{Considerations of Target Protein and Timing for Action of MicroRNAs}

In order to determine the effects of microRNAs on the immune response, it is important to consider the expression level of the targeted protein. MicroRNAs can only inhibit the production of proteins. Therefore, already existing proteins are not affected immediately by newly expressed microRNAs. This is the case for miRNA-146a, which targets IRAK-1 and TRAF-6, but also for miRNA-155 when the target is MyD88 or TAB2. All these proteins are existing proteins and part of the TLR-4 signaling pathway. These proteins are essential for proper function of the TLR-4 pathway and must respond immediately if a pathogen is detected. Upregulation of miRNA-146a or miRNA-155 will not affect these existing proteins. 
Only the re-expression of these proteins will be affected and a reduction in downstream signaling will only result in a delayed manner. Consequently, the inhibitory effect of miRNA-146a and miRNA-155 up-regulation will be delayed.

In contrast, the effect of miRNA-155 is immediate when SHIP-1/SOCS-1 are targeted; both proteins are expressed after activation of the TLR-4 pathway and act as a negative feedback loop. Up-regulation of miRNA-155 will inhibit the production of these two inhibitors of the TLR-4 pathway immediately. Consequently, up-regulation of miRNA-155 results in increased down-stream signaling. Up-regulation of miRNA-101 has the same effect. DUSP-1 is also newly expressed after stimulation of the TLR-4 pathway. The up-regulation of miRNA-101inhibits the production of DUSP-1 immediately and will also increase the activation of the p38 and JNK-arm of the MAPK-pathway. However, the Erkarm will not be affected.

\section{EFFECT OF TEMPERATURE ON MONOCYTE RESPONSE}

The effect of temperature on the monocyte response has been investigated in order to identify potential mechanisms, which may explain, why hypothermic patients experience such detrimental outcomes. Some of our own and other published data are conflicting. One of the most consistent results is the effect of hypothermia on cytokine expression in human monocytes or peripheral blood mononuclear cells (PBMCs) cultures. Hypothermia reduces the initial secretion of early, pro-inflammatory cytokines compared to $37^{\circ} \mathrm{C}$, but results in 
an increased and prolonged secretion of TNF- $\alpha$, IL-1 $1 \beta$ and IL- $624 \mathrm{~h}$ or longer after initial stimulation $(18,20,23,62,160-163)$. In contrast to the pro-inflammatory cytokines, the expression of IL-10 was found to be reduced under hypothermic conditions in the same studies and some others $(21,164)$. HLA-DR was also found to be reduced in hypothermia. Furthermore, rewarming seems to reduce the detrimental effects of hypothermia on HLA-DR expression (165).

The only study to our knowledge, which investigates cytokine levels in hypothermic patients without cardiovascular operation, was conducted in patients, who were deliberately cooled after successful out-of-hospital reanimation after cardiac arrest. In this study, IL-6 was found to be higher in the hypothermic group, whereas TNF-a was not different (166). Supporting the hypothesis that hypothermia impairs the immune response, the rate of bacterial colonization was higher in hypothermic patients although no difference in infectious complications was found. Another study in which therapeutic hypothermia after cardiac arrest was applied, found a significantly increased rate of early onset pneumonia in hypothermic patients (167). Both studies report a higher survival rate in patients with therapeutic hypothermia, which is likely due to the beneficial effect of hypothermia on the recovery of the hypoxic brain injury. In a study with brain injury patients, IL-6 was found to be elevated for a longer period in the jugular vein of normothermic patients and a much more rapid decrease in jugular IL-6 levels in hypothermic patients (168). Since the difference in IL-6 was only found in the jugular vein, IL-6 may rather mirror the cytokine levels in the brain than the systemic response to hypothermia. 
Animal models are of limited value in investigating the effects of hypothermia. In rodents, which are almost exclusively used for these experiments, the development of hypothermia is a physiologic process in sepsis and therefore probably not detrimental as it is for humans (169). Consequently, the data are conflicting. Some authors found a detrimental effect of hypothermia, whereas others proposed a beneficial effect. Torossian et al. found detrimental effects of hypothermia on survival in a bacterial peritonitis model in rats $(170,171)$. Huet et al. and Taniguchi et al. found a beneficial effect of hypothermia $(172,173)$. Importantly, these two studies used LPS as challenge and not live bacteria as Torossian et al. in their studies, which may contribute to the opposing results. All studies found an increase of IL-10 in hypothermic rodents, which is in strong contrast to the available in vitro data from human cells. In line with the human data, restoration of normothermia was found to increase survival in a bacterial peritonitis model (174). The suitability of mice for investigation of temperature regulation and effects of temperature has recently been questioned both scientifically and teleologically (175).

Besides the investigation of cytokines, some studies have examined the effect of hypothermia on gene expression and pathway activation. Fairchild et al found in a series of studies that hypothermia affects the NF-kB pathway $(19,23)$. These investigators found increased activation of IKK, delayed re-expression of IkB and prolonged nuclear localization of the NF-kB complex. These findings would explain the prolonged secretion of pro-inflammatory cytokines $(19,23)$. Arai et al. confirmed the prolonged NF-KB activation in hypothermia (164). In line with 
a profound impact of hypothermia on cell homeostasis, Sonna et al. found also a strong impact of hypothermia on the whole genome expression in the human monocytic cell line THP-1 and liver cells $(24,176)$. Interestingly, genes involved in the immune response and signaling pathways were particularly strongly affected by hypothermia. To date, there is no data on effects of hypothermia on the MAPK-pathway in monocytes or macrophages. The existing data in Human Umbilical Vein Endothelial Cells (HUVEC) and astrocytes indicates that these pathways are also affected by hypothermia $(25,177,178)$. Of particular interest is the finding of Yang et al, that the reduced JNK-activation in hypothermia in their model of ischemia/reperfusion injury is due to an increased expression of DUSP1 and not due to an increased up-stream signaling (177).

In summary, hypothermia was found to increase and prolong the secretion of pro-inflammatory cytokines and to reduce the expression of IL-10 in human cell cultures. As a possible underlying mechanism, hypothermia prolongs NF-kB activation in monocytes. 


\section{CHAPTER III}

\section{HYPOTHESIS, SPECIFIC AIMS AND EXPERIMENTAL PLAN}

\section{A) Key Objective}

To investigate the effects of clinically-relevant altered temperatures on primary monocyte function such as cytokine production and to identify mechanisms likely to be responsible for increased rate of infectious complications and death in hypothermic surgical patients.

\section{B) Hypothesis}

Hypothermia dysregulates elementary cell functions such as the activation of inflammatory signaling pathways and gene expression. We hypothesize that hypothermia increases the activation of the NF KB and MAPK-pathway. This increased pathway activation leads to increased expression of pro-inflammatory genes and miRNA-155 resulting in a prolonged secretion of pro-inflammatory cytokines in hypothermia. 


\section{C) Specific Aims}

a. Specific Aim 1: Investigation of NF-KB and MAPK pathway activation under hypothermic and hyperthermic conditions in isolated monocytes.

b. Specific Aim 2: Analysis of expression of miRNAs miR-155 at $32^{\circ} \mathrm{C}$ to $39^{\circ} \mathrm{C}$

C. Specific Aim 3: Verification of the effect of the dysregulated miRNA-155 on the cellular response through the use of miRNA mimics and antagomirs on the cytokine production.

d. Specific Aim 4: Investigation of the suppressive role of IL-10 on miRNA-155 expression and the prolonged TNF- $\alpha$ production at $32^{\circ} \mathrm{C}$ and $39^{\circ} \mathrm{C}$

\section{D) Experimental Plan}

The purpose of this project is to investigate how hypothermia modulates the monocyte response on the cellular level and which processes lead to the observed differences in cytokine secretion. We analyze each step of the monocyte response, starting with the activation of the signaling pathways NF-KB and MAPK. If we observe differences in the activation of these pathways, a subsequent difference in gene expression can be expected. Gene expression in our understanding includes mRNA and microRNAs, mainly miRNA-155 for our purposes. Identification of differential expression of miRNA-155 in hypothermia 
should result in differences in secretion of pro-inflammatory cytokines. To confirm the role of miRNA-155, we will up-regulate or suppress the expression of miRNA-155 and demonstrate its effect on TNF- $\alpha$. The last purpose of our research is to determine, which role negative feedback loops play in the regulation of the monocyte response. Modulation of the action of IL-10 allows determining its effect on cytokine gene expression and cytokine secretion as well as miRNA-155 expression. An outline of the research plan is showed in Figure 6. 
Figure 6: Research Plan and Investigated Steps of the Monocyte Response
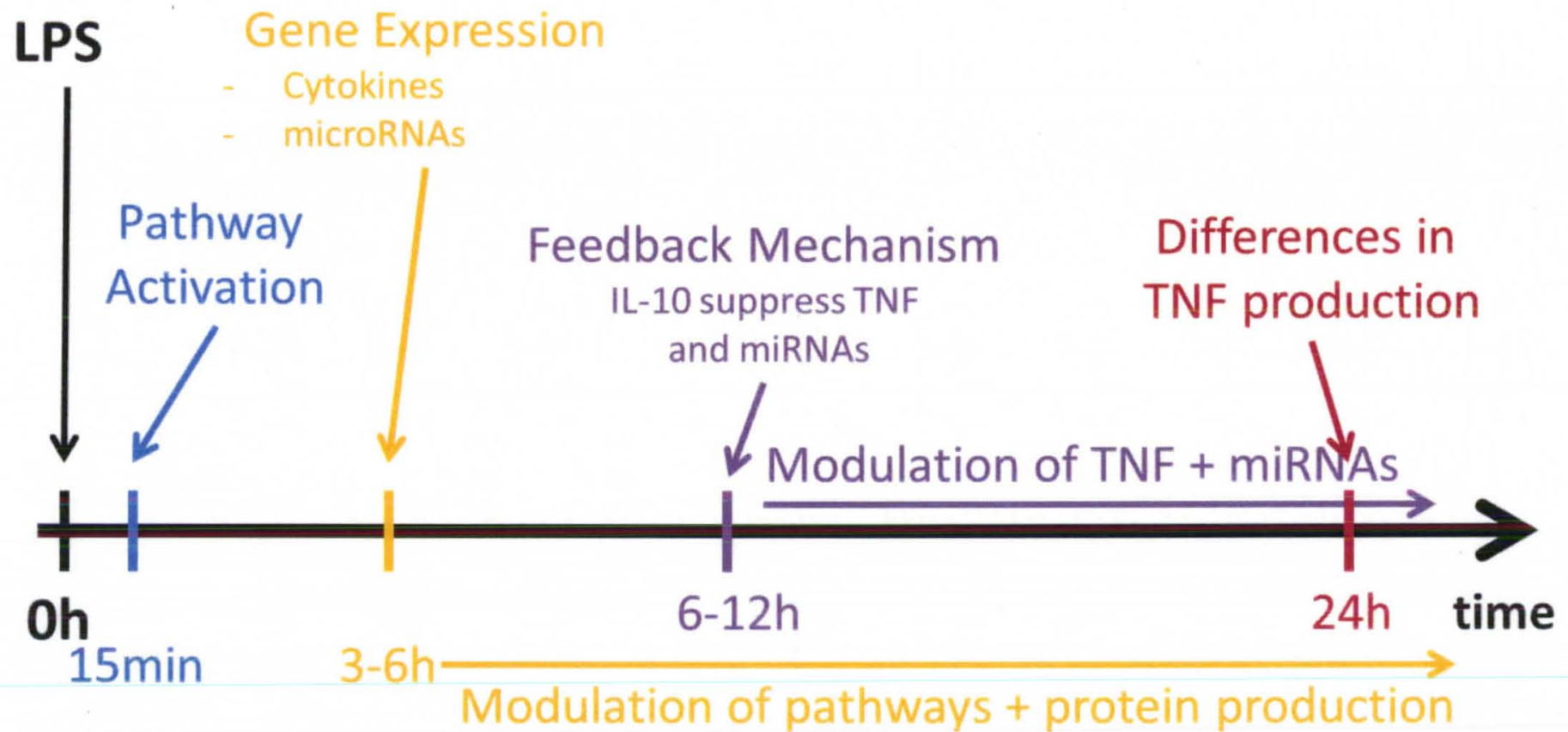

We investigate the monocyte response stepwise and determine the effect of hypothermia on each of these steps.

The first step is the activation of the NF-KB and MAPK-pathway followed by the expression of cytokine mRNA and miRNA-155. The role of miRNA-155 on TNF- $\alpha$ secretion and the impact of the negative feedback loop of IL-10 on miRNA-155 is also analyzed. 


\section{E) Methods}

\section{E1) Study Subjects}

Approval of the study protocol was obtained from the University of Louisville Institutional Review Board prior to enlisting any study subjects (HSPPO 08.0018). Written informed consent was obtained from all participants. Volunteers with any signs of acute sickness, history of chronic conditions such as diabetes mellitus or immune-suppressive disorder and subjects with chronic medication use were excluded. We enrolled a total of 16 healthy donors, although the majority of experiments were conducted with seven donors per experiments. The age of the participants ranged from $19-49$ years.

\section{E2) Monocyte Isolation}

Venous blood was collected in EDTA Vacutainers (Becton Dickinson, Franklin Lakes, NJ). Primary human monocytes were isolated using the magnetic cell sorting technique according to manufacturer's instruction. The collected whole blood was incubated with Human CD14 MicroBeads (Miltenyi Biotec, Auburn, CA) for $15 \mathrm{~min}$ in an incubator at $37^{\circ} \mathrm{C}$. After washing, the blood was resuspended in the original volume with MACS Separation Buffer (Miltenyi Biotec, Auburn, CA) and run through Whole Blood Columns (Miltenyi Biotec, Auburn, CA). After isolation, the columns were washed three times and the monocytes eluted from the columns with MACS Elution Buffer (Miltenyi Biotec, Auburn, CA). 
The cells were washed twice with Phosphate Buffered Saline (PBS) and counted. The purity of the isolated monocytes was $>95 \%$ as determined by Flow Cytometry.

The primary monocytes were cultured in 1640 RPMI medium (MP Biomedicals, Solon, $\mathrm{OH}$ ) supplemented with $10 \%$ heat-inactivated defined Fetal Bovine Serum, 2nM L-Glutamine and 100IU/ml penicillin, 100 $\mathrm{g} / \mathrm{ml}$ streptomycin and $250 \mathrm{ng} / \mathrm{ml}$ amphotericin B (all items purchased from Thermo Scientific, Waltham, MA). Cells were cultured in a concentration of $0.25 \times 10^{6} \mathrm{cells} / \mathrm{ml}$ in a humified incubator with $5 \% \mathrm{CO}_{2}$. The temperature varied according to the experimental conditions. In general, the monocytes were cultured at $32^{\circ} \mathrm{C}$ or $39^{\circ} \mathrm{C}$ for the different experiments. $39^{\circ} \mathrm{C}$ was chosen to avoid the strong induction of a heat shock response (179-181). Preliminary experiments with $34^{\circ} \mathrm{C}$ and $37^{\circ} \mathrm{C}$ demonstrated higher TNF-a levels and lower $\mathrm{IL}-10$ levels in $34^{\circ} \mathrm{C}$ compared to $37^{\circ} \mathrm{C}$. However, the high inter-subject variation of the cytokine response ameliorated some of the temperature differences. We therefore decided to use $32^{\circ} \mathrm{C}$ and $39^{\circ} \mathrm{C}$ in order to enhance the temperature induced differences. If the cells were rested or stored, the culture temperature was $37^{\circ} \mathrm{C}$. The monocytes were cultured in $50 \mathrm{ml}$ polypropylene tubes as cell suspension.

Lipopolysaccharide (LPS), 100ng per $0.25 \times 10^{6}$ cells (E. coli 0111:B4; Sigma-Aldrich Co., St. Louis, MO) was used for stimulation. After incubation for the indicated time-periods, the monocytes were centrifuged, the supernatant was collected and stored at $-80^{\circ} \mathrm{C}$ until measurement. The 
cell pellet was washed with PBS and transferred to $1.5 \mathrm{ml}$ centrifugation tubes and centrifuged for 3min at 10,000rpm (Eppendorf MiniSpin).

\section{E3) Phosflow Pathway Analysis}

For the pathway analysis, the freshly isolated monocytes were rested at $37^{\circ} \mathrm{C}$ for $24 \mathrm{~h}$ until further use. After $24 \mathrm{~h}$, cells were washed and resuspended in fresh medium (10\% FBS supplemented 1640 RPMI). Cells were stimulated with LPS (100ng per $0.25 \times 10^{6}$ cells) and then incubated for the indicated time points at either $32^{\circ} \mathrm{C}$ or $39^{\circ} \mathrm{C}$. There was no preincubation at the corresponding temperature. For definition of baseline pathway activation, unstimulated monocytes cultured at $37^{\circ} \mathrm{C}$ for the duration of the experiment were used ( $=0 \mathrm{~h}$ time point).

In preliminary experiments, we also investigated the activation of $\mathrm{NFKB}$ at $37^{\circ} \mathrm{C}$. Table 1 shows the Mean Channel Fluorescence (MCF) at $15 \mathrm{~min}$ and $20 \mathrm{~min}$ after LPS at $32^{\circ} \mathrm{C}, 37^{\circ} \mathrm{C}$ and $39^{\circ} \mathrm{C}$. NFKB activation at $37^{\circ} \mathrm{C}$ lies between $32^{\circ} \mathrm{C}$ and $39^{\circ} \mathrm{C}$.

After the indicated time, the monocytes were immediately fixed for $10 \mathrm{~min}$ at $37^{\circ} \mathrm{C}$ with a pre-warmed Formaldehyde solution (final concentration $3.2 \%$ ) in order to preserve the phosphorylation status of the pathways. Cells were then washed twice with wash Buffer containing FBS (FBS wash Buffer, BD Bioscience, San Jose, CA). The monocytes were permeabilized with pre-chilled $100 \%$ methanol at $-20^{\circ} \mathrm{C}$ for $30 \mathrm{~min}$ in order to allow the antibodies access to the pathway epitopes. After three 
washes, cells were resuspended in $100 \mu$ FBS-wash buffer and separated into two tubes. One tube was used for analysis of NF-KB and p38 activation; the second tube was used for analysis of Erk and JNK activation. Samples were stained for $1 \mathrm{~h}$ in the dark at room temperature. The following antibodies were used (all BD Bioscience Phosflow antibodies, San Jose, CA): phospho-p38 MAPK (pT180/pY182), Alexa Fluor( 488; phospho-ERK1/2 (pT202/pY204), Alexa Fluor® 488; phospho-JNK (pT183/pY185), Alexa Fluor® 647; NF-KB p65 (pS529), Alexa Fluor@ 647 .

After staining, cells were washed twice and resuspended in $250 \mu \mathrm{l}$ FBS-wash buffer and immediately analyzed. A FACS Calibur (BD Bioscience, San Jose, CA) was used to acquire the samples. We counted 10,000 events for each sample. The freely available online-software cytobank.org, which was specifically developed for analysis of Phosflow samples, was used for analysis. Example histograms for NF-kB activation are shown in Figure 7.

\section{E4) RNA Isolation}

Total RNA was isolated from the monocyte pellet using the RNeasy Mini Kit (Qiagen, Valencia, CA). Concentrations and purity of the RNA were determined with the Nanodrop N-1000 (Agilent Biosystems, Santa Clara, CA). All samples fulfilled the quality criteria (A260/A260 ratio between 1.9 and 2.1). 
Table 1: NFkB Peak Activation at $32^{\circ} \mathrm{C}, 37^{\circ} \mathrm{C}$ and $39^{\circ} \mathrm{C}$

\begin{tabular}{|c|c|c|}
\hline Temperature & $\begin{array}{c}15 \mathrm{~min} \text { post LPS } \\
(\mathrm{MCF})\end{array}$ & $\begin{array}{c}20 \mathrm{~min} \text { post LPS } \\
\text { (MCF) }\end{array}$ \\
\hline $32^{\circ} \mathrm{C}$ & 1148.31 & 1061.81 \\
\hline $37^{\circ} \mathrm{C}$ & 1099.83 & 975.83 \\
\hline $39^{\circ} \mathrm{C}$ & 975.23 & 772.36 \\
\hline
\end{tabular}

Comparison of peak activation between $32^{\circ} \mathrm{C}, 37^{\circ} \mathrm{C}$ and $39^{\circ} \mathrm{C}$ of the $N F_{K} B$ pathway in one preliminary experiment. The highest activation is recorded at $32^{\circ} \mathrm{C}$ and remains elevated. The lowest activation is measured at $39^{\circ} \mathrm{C}$ while $37^{\circ} \mathrm{C}$ is in between.

MCF: mean channel fluorescence 
Figure 7: Example of NF-kB Activation at $32^{\circ}$ and $39^{\circ} \mathrm{C}$
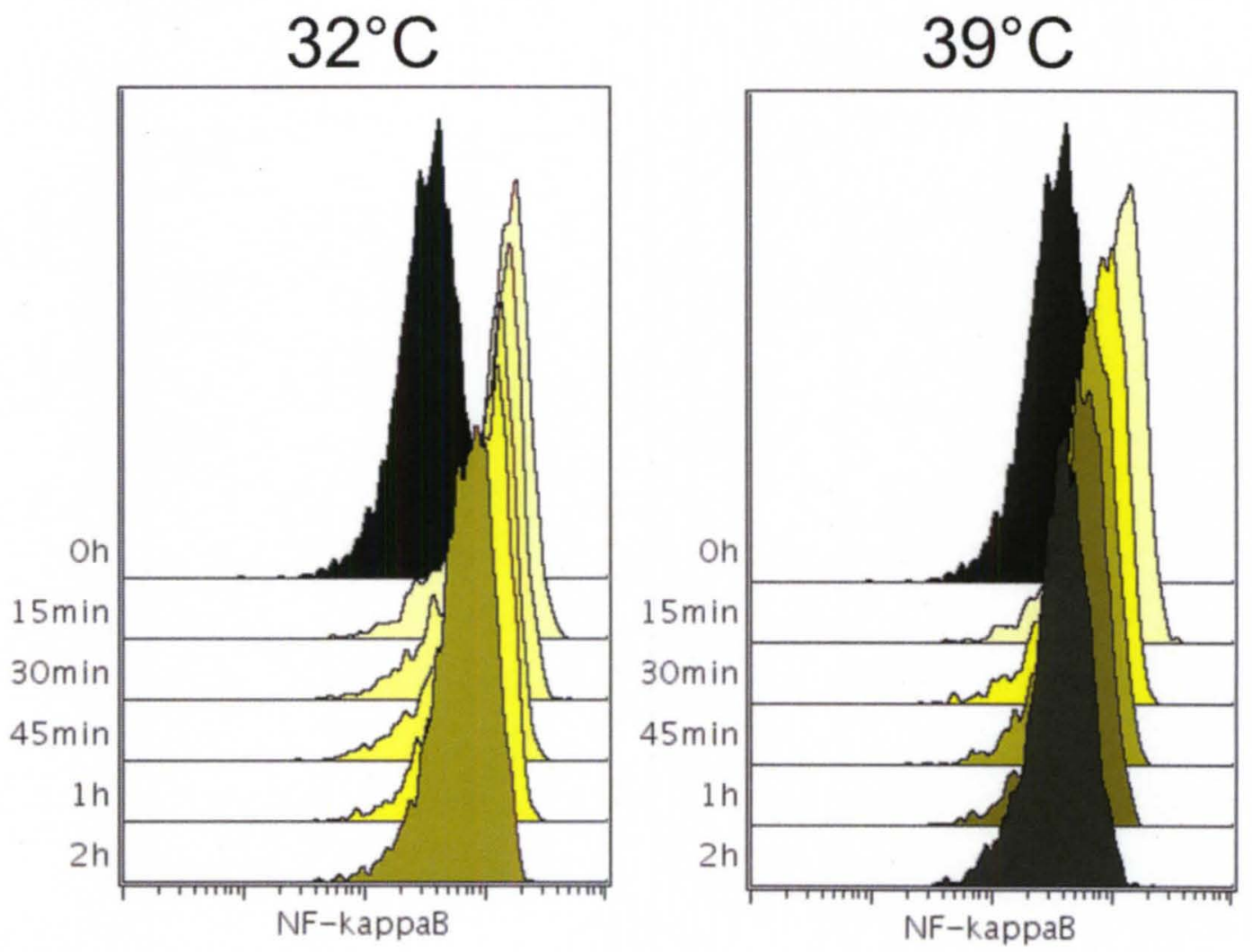

Example of histograms demonstrating the activation of the NF-KB pathway at $32^{\circ} \mathrm{C}$ and $39^{\circ} \mathrm{C}$. The $x$-axis reflects the degree of activation (mean channel intensity in a logarithmic scale). In addition, the degree of activation is color-coded with brighter colors indicating a higher degree of activation. The different levels of histograms in the $y$-axis indicate the different time points. The $2 \mathrm{~h}$ time point at $39^{\circ} \mathrm{C}$ reaches almost baseline levels, whereas $32^{\circ} \mathrm{C}$ remains clearly activated. In addition, the peak level of activation at $32^{\circ} \mathrm{C}$ is higher than at $39^{\circ} \mathrm{C}$. 


\section{E5) Cytokine Measurements}

TNF- $a$, IL- 6 , and IL-10 levels were determined by enzyme-linked immunosorbent assays (ELISA) (eBioscience, San Diego, CA) in 96-well plates according to manufacturer's protocol. All samples were analyzed in duplicates; cytokine levels of samples were determined by a standard curve using recombinant human TNF-a, IL-6, or IL-10.

\section{E6) MicroRNA and MessengerRNA Expression}

For expression analysis of miRNA-155 TaqMan single microRNA assays were used according to manufacturer's instruction (Life Technologies, Foster City, CA). The housekeeping gene U6 was used for normalization. An exemplary amplification plot is shown in Figure 8.

For expression of TNF- $\alpha$ and IL-10 mRNA, complementary DNA (cDNA) was generated using the High Capacity cDNA Reverse Transcription Kit (Life Technology, Foster City, CA). TaqMan single gene assays for human TNF- $\alpha$ and IL-10 (Life Technologies, Foster City, CA) were then used for assessment of gene expression. 18s was chosen as internal control.

The Polymerase Chain Reactions (PCR) were run on a StepOne Plus RealTime-PCR-System using Fast Advanced Master Mix and the fast protocol (all products purchased from Life Technologies, Foster City, CA). Fold changes were calculated using the $\triangle \Delta C T$-method (182). 
Figure 8: Exemplary Amplification Plot for miRNA-155

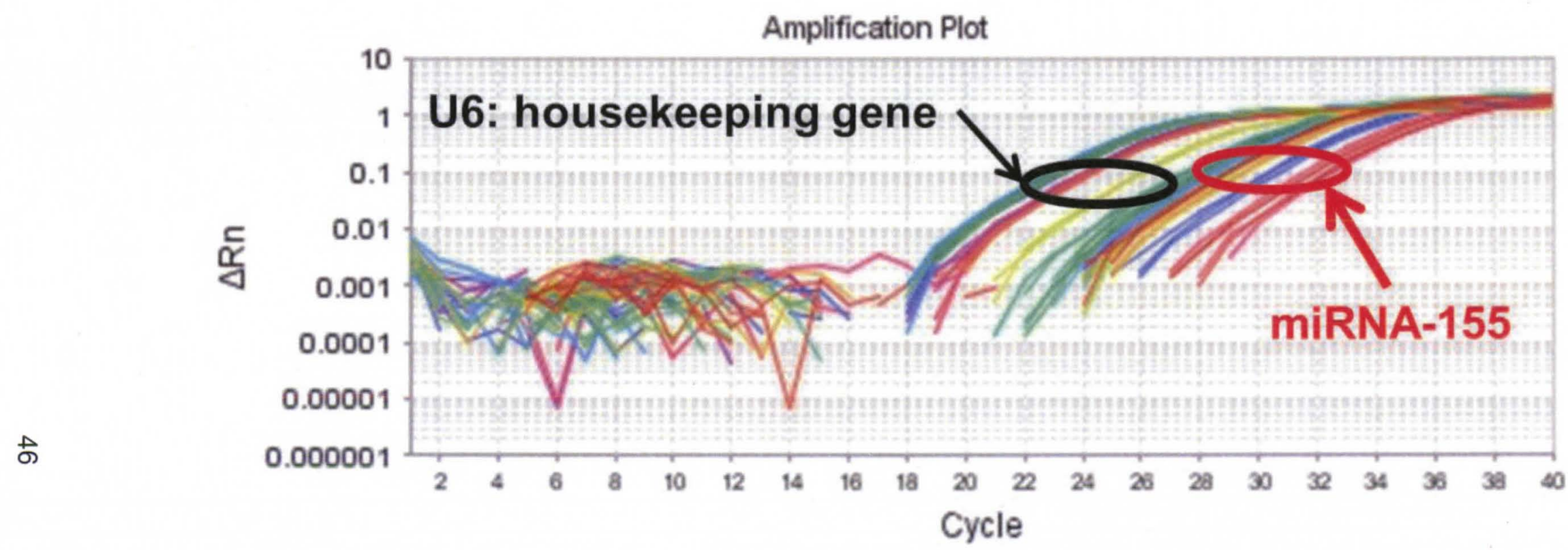

The $x$-axis indicates the cycle threshold $(C t)$, which is used to determine the $\Delta C t$-value. The $y$-axis is logarithmic and shows the level of fluorescence. Amplification of a gene increases the fluorescence exponentially. The difference in Ct-values between the housekeeping gene U6 and miRNA-155 is used to calculate the $\Delta C t$. The difference between the control sample and the sample of interest allows the determination of the $\Delta \Delta C t$, which can be transformed into Fold Change. 


\section{E7) MicroRNA-Transfection}

In order to demonstrate the effect of miRNA-155 on the prolonged expression of pro-inflammatory cytokines, we transfected the monocytes with miRNA-155 mimics and antagomirs. MicroRNA-mimics are premicroRNAs, which are processed by Dicer and become part of the RISC and act in the same way as endogenous microRNAs. MicroRNAantagomirs are the anti-sense strand of the mature microRNA of interest. The binding of the antagomir with the target microRNA leads to the degradation of the microRNA by the same process as described for silencing RNAs (siRNA) (183). Negative controls are RNA-strands, which have the same hairpin structure like a natural pre-microRNA and are also processed by Dicer. However, the seed-sequence of the negative controls is not complementary to any known gene and has therefore no biologic action.

For this experiment, monocytes were isolated as described and then immediately transfected with either miRNA-155 mimic, negative control or miRNA-155 antagomir. We used the N-TER nanoparticle transfection system for this purpose according to the manufacturer's instructions (Sigma-Aldrich Co., St. Louis, MO). The miRNA-155 mimic and negative control were incubated in a concentration of $40 \mathrm{nM}$, whereas the miRNA-155 was incubated in a concentration of $80 \mathrm{nM}$. MicroRNAmimics, antagomirs and negative control were purchased from Ambion (Life Technologies, Foster City, CA). 
After $24 \mathrm{~h}$ of transfection, the cells were washed and resuspended in fresh RPMI-media with 10\% FBS. The cells were then stimulated with LPS for another $24 \mathrm{~h}$ at the appropriate temperature, $32^{\circ} \mathrm{C}$ or $39^{\circ} \mathrm{C}$. After 24h of LPS-stimulation, the supernatant was collected for cytokine measurements and the total RNA was isolated for analysis of microRNA expression. Cell viability at all time points was $>90 \%$ as determined by flow cytometry and Trypan Blue.

\section{E8) IL-10 Addition / Anti-IL-10-Receptor Blockade}

In order to elucidate the role of the IL-10 feedback loop, we added recombinant human IL-10 (rhIL-10, Sigma-Aldrich Co, St. Louis, MO) or blocked the action of IL 10 by blocking the IL-10 receptor. For the IL-10 addition experiment, monocytes were isolated and stimulated with LPS at $32^{\circ} \mathrm{C}$ or $39^{\circ} \mathrm{C}$ as outlined above. After 4 h of LPS-stimulation, 20ng of rhIL10 for a final concentration of $5 \mathrm{ng} / \mathrm{ml}$ were added to the cell culture tubes in both temperatures for the remaining time of $12 \mathrm{~h}$ and $24 \mathrm{~h}$. The $4 \mathrm{~h}$ time point at which IL-10 was added was chosen based on preliminary experiments. At this time point, IL-10 is being secreted by monocytes after LPS stimulation.

In order to block the action of IL-10 the isolated monocytes were incubated for $1 \mathrm{~h}$ at $37^{\circ} \mathrm{C}$ with $10 \mu \mathrm{g}$ of anti-human IL-10-receptor antibody ( $\alpha$-subunit, Sigma-Aldrich, St. Louis, MO). We performed a dilution series 
in order to determine the amount of anti-IL-10-receptor antibody, which can block the action of IL-10 (Figure 9). After incubation with the antibody, cells were stimulated with LPS and incubated for the indicated time point at $32^{\circ} \mathrm{C}$ and $39^{\circ} \mathrm{C}$. These experiments were conducted with the same donor at the same time with both treatments in both temperatures. In addition, untreated samples cultured at $32^{\circ} \mathrm{C}$ or $39^{\circ} \mathrm{C}$ were used as controls. At the indicated time points, supernatant was collected and total RNA isolated until further analysis.

\section{E9) Statistical Analysis}

For all experiments, monocytes from the same person were used and the different temperatures or treatments were compared against each other within the same person. Therefore, a related sample test was used. For two comparisons, the Wilcoxon ranked sign-test was used; for multiple comparisons, Friedman's Two-Way Analysis of Variance by Ranks was used. Data are presented as mean \pm SEM. SigmaPlot 11.0 was used for presentation of the data (Systat Software Inc., San Jose, CA). Statistical analysis was performed with SPSS 18.0 (PASW Statistics 18, IBM, Chicago, IL). Results were considered significant at $p<0.05$. 
Figure 9: Effect of Different Amounts of Anti-IL-10 Receptor Antibody on TNF- $\alpha$ and miRNA-155
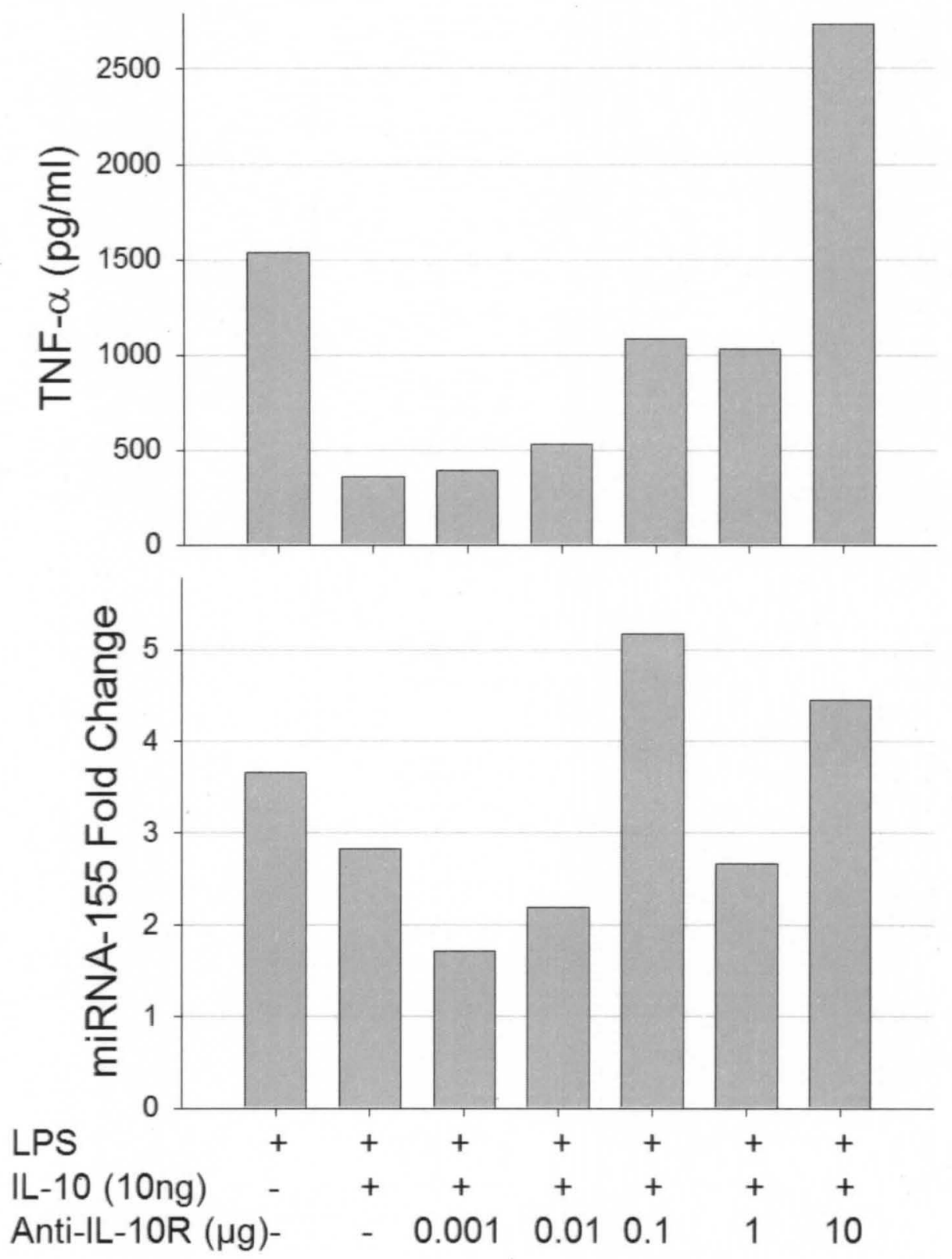

Blockade of the IL-10-Receptor results in a dose-dependent increase in TNF- $\alpha$ and miRNA-155. 


\section{CHAPTER IV}

\section{EFFECT OF TEMPERATURE ON CYTOKINE EXPRESSION}

The secretion of cytokines by cells of the immune system serves several important purposes. Cytokines serve as messengers among different immune cells and coordinate the immune response in order to contain infections $(47,51)$. The first step in a successful engagement of the immune system is the signal that an invading pathogen has been discovered. This signal attracts other leukocytes in relatively large numbers with the goal to clear the infection. Tissue macrophages and dendritic cells serve exactly this cause. These cells patrol through the tissues and phagocytize foreign and endogenous material. Pathogens such as bacteria are recognized by a variety of receptors like the TLR-4 receptor $(72,79,80)$. These receptors signal through signaling pathways and induce secretion of cytokines. The first response is the secretion of preformed cytokines, which are stored in vesicles. Secretion of these preformed cytokines allows an immediate response to any signs of danger. These proinflammatory cytokines activate the local endothelial cells and attract other immune cells such as neutrophils and monocytes from the blood. These cells evade at the site of the infection the blood stream and engage in the immune defense replenishing and supporting the local cells. 
The second purpose of cytokines, after activation of the initial immune response, is to limit the host response to the infected tissue and avoid damage to the host. An uncontrolled release of pro-inflammatory cytokines may lead to severe, detrimental effects such as generalized vasodilation resulting in shock or systemic activation of the coagulation system known as disseminated intravascular coagulation (DIC) $(75,91)$. To prevent the systemic spread of the immune response, anti-inflammatory feedback loops are automatically activated after the first detection of LPS by a local tissue macrophage $(56,97-100)$.

IL-10 was the first described anti-inflammatory cytokine. Its original name human cytokine synthesis inhibitory factor (CSIF) describes clearly what the function of IL-10 is. IL-10 suppresses the production of pro-inflammatory cytokines directly in any immune cell. It also stimulates its own production and the production of other, anti-inflammatory cytokines such as Transforming Growth Factor- $\beta$ (TGF- $\beta$ ). Furthermore, IL-10 induces the development of a certain subtype of T-helper cells such as $T_{H} 2 T$-cells and regulatory $T$-cell $\left(T_{\text {regs }}\right)$. $T_{H} 2 T$-cells stimulate wound healing and the switch of B-cells to the production IgG-antibodies (47). This is in contrast to the $T_{H} 1 \mathrm{~T}$-cell, which produces proinflammatory cytokines and stimulate the activity of macrophages and cytotoxic T-cells (CD8+). $T_{\text {regs }}$ are another subtype of T-cells, which suppress the immune system. The exact mechanism how these cells function remains unclear. It has been suggested that they secret IL-10 and suppress the function of proinflammatory immune cells by transferring anti-inflammatory microRNAs such as miRNA-146a into T-cells $(184,185)$. 
Taking together, these results suggest that the key to an appropriate immune response is the balanced production of first pro-inflammatory cytokines followed by the production of anti-inflammatory cytokines. It has been suggested that a cause for the post-traumatic multiple organ dysfunction syndrome (MODS) without sepsis is prolonged and unbalanced secretion of pro-inflammatory cytokines $(186,187)$. In this concept, the increased and prolonged secretion of pro-inflammatory cytokines is followed by a profound and prolonged suppression of the immune system, also described as immune-paralysis or Compensatory Anti-Inflammatory Response Syndrome (CARS).

Hypothermia dysregulates the secretion of cytokines and this effect may contribute to the detrimental effect of hypothermia. The available data in human in vitro cultures indicate that hypothermia results in a delayed, but increased and prolonged secretion of pro-inflammatory cytokines after LPS stimulation $(18,20,161,163)$. In contrast, hypothermia decreases the production of antiinflammatory cytokines such as IL-10 $(21,22,163)$.

The purpose of the first experiment was to determine, how hypothermia affects the production of cytokines in our model and if we can reproduce the published results. 


\section{RESULTS}

\section{Monocyte Purity and Viability}

In order to achieve reliable results from our investigations, we first determined the purity of our monocyte culture. We confirmed a purity $>95 \%$ after the isolation process for every donor. An example of a flow scatter plot is shown in Figure 10. Next, we monitored the viability of the monocytes over time. Figure 10 also demonstrates a scatter plot of a sample of the same donor after $36 \mathrm{~h}$ of LPS stimulation at $39^{\circ} \mathrm{C}$. There is a slight increase in size and granularity of the monocytes as indicated by a shift of the population to the right (size) and upwards (granularity). These changes are explained by the stimulation with LPS and the subsequent response of monocytes with production of cytokines and phagosomes. Importantly, there is no significant change of cells outside the gate (R1), which would indicate disintegration and necrosis or apoptosis of the monocytes. 
Figure 10: Flow Scatter Plot of Freshly Isolated Monocytes and 36h after LPS Stimulation
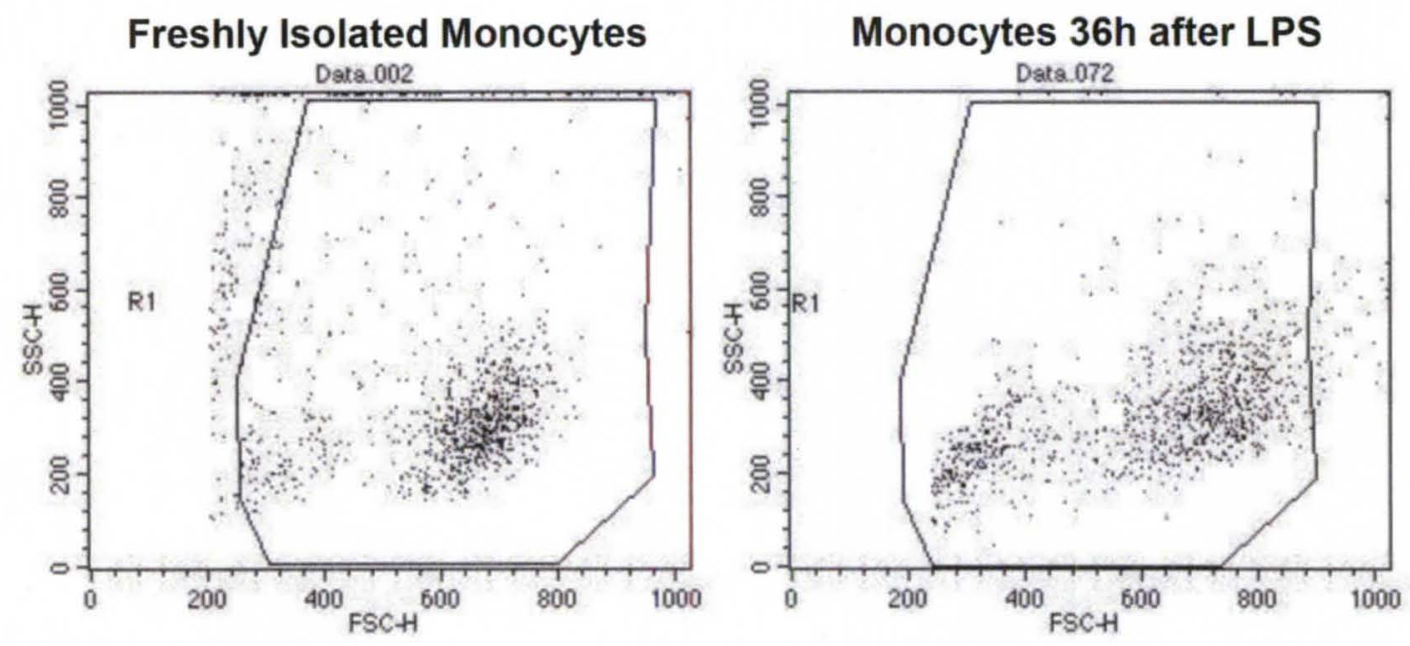

One distinct cell population can be determined in both graphs. The size (forward scatter - FSC) and granularity (side scatter - SSC) are typical for monocytes. Events outside the left side of gate $R 1$ are considered cell debris such as partial lysed red cells or platelets, which remain in a low amount after the isolation process. The monocyte population remains at the same location after $36 \mathrm{~h}$ of LPS stimulation. However, there is a slight increase in size (shift to the right on the forward scatter - FSC) and granularity (upwards shift on the side scatter- SSC). This is a typical finding of activated monocytes. There is an insignificant increase of cells in the left side of gate $R 1$. These cells are intact and express all receptors but are becoming necrotic or apoptotic. 


\title{
Secretion of Pro-Inflammatory Cytokines
}

\author{
Tumor Necrosis Factor Alpha - TNF-a
}

Figure 11 shows TNF-a levels over $36 \mathrm{~h}$ at $32^{\circ} \mathrm{C}$ and $39^{\circ} \mathrm{C}$, respectively. The TNF-a levels rose quickly after LPS-stimulation. Six hours after LPSstimulation TNF- $\alpha$ levels were significantly higher at $39^{\circ} \mathrm{C}$ than at $32^{\circ} \mathrm{C}(p<$ 0.001). The TNF-a levels at $39^{\circ} \mathrm{C}$ peak at $12 \mathrm{~h}$ and decay rapidly over the next 24h. In contrast, the rise of TNF- $\alpha$ at $32^{\circ} \mathrm{C}$ is delayed but peaks at $24 \mathrm{~h}$ with only little decrease at $36 \mathrm{~h}$. The differences in TNF- $a$ are significant at $24 \mathrm{~h}$ and $36 \mathrm{~h}$ between $32^{\circ} \mathrm{C}$ and $39^{\circ} \mathrm{C}(\mathrm{p}<0.05)$.

Interleukin-6 - IL-6

Changes in IL-6 were comparable to TNF- $\alpha$. Similar to TNF- $\alpha$, IL-6 increases rapidly at $39^{\circ} \mathrm{C}$ at $6 \mathrm{~h}$ and is significantly higher than at $32^{\circ} \mathrm{C}$ (Figure 11). This initial response was very uniform among the different donors as indicated by the small error bars. At $12 \mathrm{~h}$ and $24 \mathrm{~h}$, there was no difference between the two temperatures but the $\mathrm{IL}-6$ levels at $32^{\circ} \mathrm{C}$ increased until the $36 \mathrm{~h}$ time point whereas the $\mathrm{IL}-6$ levels at $39^{\circ} \mathrm{C}$ peak at $24 \mathrm{~h}$ and begin to decrease afterwards. The prolonged and increased secretion of $\mathrm{IL}-6$ at $32^{\circ} \mathrm{C}$ led to significantly different IL-6 levels at $36 \mathrm{~h}$. Of note, there was considerable variation of IL-6 levels among the different subjects as indicated by the large error bars. Because every donor showed a similar influence of temperature on IL-6, the differences at $36 \mathrm{~h}$ are statistically significant. 


\section{Secretion of Anti-Inflammatory Cytokine}

Interleukin-10 - IL-10

Changes in the levels of IL-10 were reversed in comparison with TNF- $\alpha$ and IL-6 (Figure 11). IL-10 started to rise with very low levels at $6 \mathrm{~h}$ at $39^{\circ} \mathrm{C}$ whereas essentially no $\mathrm{IL}-10$ was detectable at $32^{\circ} \mathrm{C}$. After $6 \mathrm{~h}$, the $\mathrm{IL}-10$ levels rose notably at $39^{\circ} \mathrm{C}$ until they reached a peak at $24 \mathrm{~h}$ followed by a slight decrease. In clear contrast to $39^{\circ} \mathrm{C}, \mathrm{IL}-10$ rose slowly at $32^{\circ} \mathrm{C}$ and never reached comparable levels. The IL-10 differences between the two temperatures are statistically highly significant at every time point (all $p<0.001$ ). 
Figure 11: TNF- $\alpha, \mathrm{IL}-6$ and IL-10 Over $36 \mathrm{~h}$ at $32^{\circ} \mathrm{C}$ and $39^{\circ} \mathrm{C}$
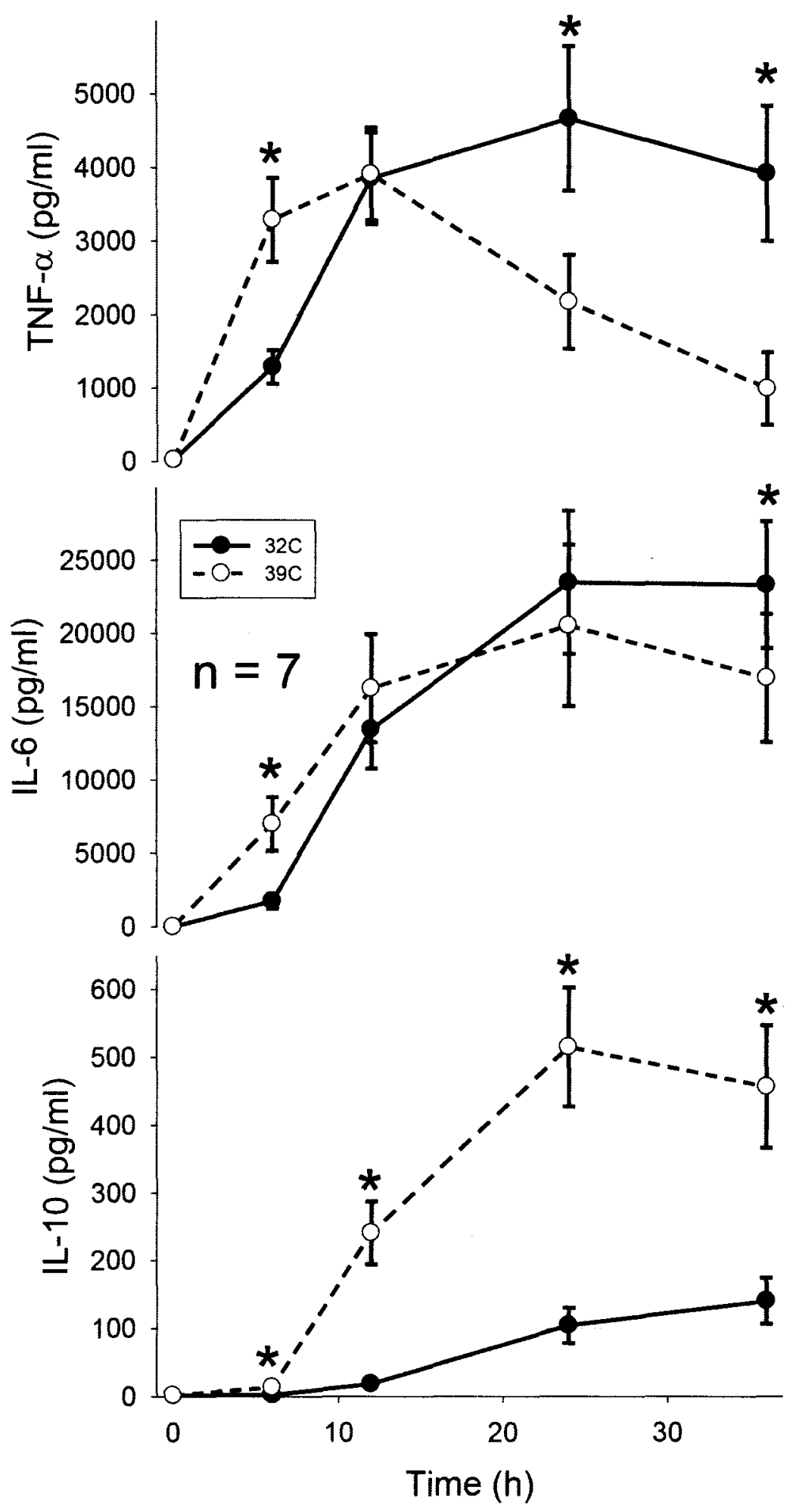


\section{Legend Figure 11}

Both pro-inflammatory cytokines show a comparable influence of temperature. At $6 \mathrm{~h}$, the levels of TNF- $\alpha$ and $I L-6$ are higher at $39^{\circ} \mathrm{C}$. However, at the prolonged time points $24 \mathrm{~h}$ and $36 \mathrm{~h}, \mathrm{TNF}-\alpha$ and $\mathrm{IL}-6$ are higher at $32^{\circ} \mathrm{C}$.

In contrast, $I L-10$ is higher at $39^{\circ} \mathrm{C}$ at all time points. The $I L-10$ levels at $32^{\circ} \mathrm{C}$ never reach comparable levels to $\mathrm{IL}-10$ at $39^{\circ} \mathrm{C}$.

* indicates $p<0.05$; data are presented as mean \pm SEM 


\section{DISCUSSION}

Cytokines are important players in the immune response because they are the first response after recognition of a pathogen or tissue injury and this initial response is also the trigger of a sequence of events, which should result in clearance of the infection without damaging the host. Therefore, an inappropriate secretion of cytokines may result in detrimental effects on the host. An unbalanced, exaggerating immune response can induce tissue damage, shock, multiple organ dysfunction and ultimately death $(75,186)$. An insufficient immune response is not able to contain the infection and would result in a first local than systemic spread of the pathogens resulting in an overwhelming infection.

Hypothermia has been shown to affect the secretion of cytokines $(18,20,161)$. The available data of human cell cultures indicates that hypothermia diminishes the early response but results in a prolonged and increased production of pro-inflammatory cytokines. There is an on-going debate, which part of the response is clinically more important. Depending on the focus of the authors, some reports underline the diminished pro-inflammatory response in the early phase $(20,178)$. Others believe that the prolonged and sustained secretion of pro-inflammatory cytokines is more important and will have long lasting effect on the ability of the host to fight infections. The data on anti-inflammatory cytokines is sparse. In vitro models demonstrate in general a decrease in IL-10 production in hypothermia $(20,21)$.

I believe that the prolonged and increased production of pro-inflammatory cytokines such as TNF- $\alpha$ and IL- 6 is more important for the long-term than the 
initial reduction in pro-inflammatory cytokines in hypothermia. Exaggerated production of TNF-a can induce multiple organ failure and death (91). The more important effect of hypothermia in our results seems to be on the counterregulatory part of the immune response, the anti-inflammatory phase. Administration of IL-10 can reduce almost all of the detrimental effects of TNF- $\alpha$ $(97,98)$. We found that IL-10 was consistently higher at $39^{\circ} \mathrm{C}$ than at $32^{\circ} \mathrm{C}$ and believe that this result may be of greater importance and the lack of IL-10 at $32^{\circ} \mathrm{C}$ may influence the prolonged pro-inflammatory response. The value of an appropriate anti-inflammatory immune response has been demonstrated in several models, in which the exaggerated secretion of pro-inflammatory cytokines is the main pathophysiologic mechanism of shock and administration of IL-10 can rescue these animals $(97,98)$. Others have found that IL-10 is the primary inhibitor of leukocyte influx in the peritoneum and that macrophages are the principle source, also indicating the importance of counter-regulatory mechanisms (188).

Taking together, these results suggest that hypothermia shifts the overall response pattern of the monocytes into a pro-inflammatory response with a prolonged and increased secretion of pro-inflammatory cytokines. At the same time, the natural negative feedback loop with IL-10 seems to be suppressed in hypothermia. In contrast, $39^{\circ} \mathrm{C}$ results in a reduced and shortened immune response with a strong induction of the anti-inflammatory IL-10. 


\section{CHAPTER V}

\section{ANALYSIS OF THE NF-K-B AND MAPK SIGNALING PATHWAYS AT DIFFERENT TEMPERATURES}

Intracellular signaling pathways control the response of the cell by integrating signals from surface receptors as well as other information on cell homeostasis $(109,121,123)$. Detection of pathogen associated molecules, the socalled PAMPs, by surface and intracellular PRR's results in a strong activation of stress response pathways. Two major stress response pathways are the NF-KB and the MAPK-pathway. Both pathways activate the production of proteins, which increase the stress resistance of the cell such as heat shock proteins. The expression of these proteins is essential; otherwise the cell would not survive the insult $(180,181,189)$. In addition to supporting the survival of the cell, heat shock proteins also serve as endogenous danger signals for the immune system (alarmins) amplifing the immune response (77). The second goal of the activation of the signaling pathways is to orchestrate the response of the whole body in order to eliminate the invading pathogen. Pro-inflammatory cytokines have local effects, which result in the extravasation of immune cells but also systemic effects such as fever and the initiation of the acute phase response. All of these measures enhance the ability of the host to defend it. 
Modulation of the activation of these pathways has therefore a profound effect on the response of the cell. Temperature has been shown to affect pathway activation profoundly $(23,160,177)$. In human monocytic cell lines, NF-kB activation was found to be increased and prolonged in hypothermia $(19,23)$. In human endothelial cells, JNK activation was decreased in hypothermia leading to decreased apoptosis (177). The data on endothelial cells cannot necessarily be directly adapted to monocytes because the stimuli for the cells are different and also so is the response pattern to stress. To our knowledge, there is no data available on pathway activation under hypothermic conditions in primary human monocytes.

Based on the previous results with highly distinct cytokine secretion between $32^{\circ} \mathrm{C}$ and $39^{\circ} \mathrm{C}$, we hypothesize that the activation of the NF-KB and MAPK-pathway is different. A prolonged activation of the pro-inflammatory pathways, NF-KB, p38 and JNK would explain the prolonged TNF- $\alpha$ secretion at $32^{\circ} \mathrm{C}$. The strong production of IL-10 at $39^{\circ} \mathrm{C}$ might also be explained by differences in pathway activation. The mechanism, which lead to the production of IL-10 are poorly understood and vary greatly among different cell types (99). However, the available data suggests that the Erk-pathway is pivotal for the induction of IL-10 in macrophages (99).

The purpose of this experiment was to assess the activation of both, the NF-KB and MAPK pathway under hypothermic conditions $\left(32^{\circ} \mathrm{C}\right)$ in the same cell at the same time and compare it to $39^{\circ} \mathrm{C}$. Measuring the activation of these 
pathways in the same experiment and same primary cells reduces the confounding factor of repetitive experiments and the associated variation.

\section{RESULTS}

\section{Activation of the NF-kB pathway}

NF-KB was rapidly activated peaking $15 \mathrm{~min}$ after LPS stimulation in both temperatures (Figure 12). After 15min, there was a decrease in NF-KB activation until $2 \mathrm{~h}$ at both temperatures. The degree of activation of NF-KB at $32^{\circ} \mathrm{C}$ was significantly higher at $15 \mathrm{~min}$ than at $39^{\circ} \mathrm{C}$. This difference in activation remained over the whole investigated period. NF-KB was increased and its activation was sustained at $32^{\circ} \mathrm{C}$ at every measured time point. Of note, NF-KB remained activated at $32^{\circ} \mathrm{C}$ at $2 \mathrm{~h}$, whereas at $39^{\circ} \mathrm{C}$, the degree of activation reached baseline values.

\section{Activation of p38 of the MAPK-pathway}

Similar to NF-KB, p38 was also maximally activated after $15 \mathrm{~min}$ followed by a decrease in activation until $2 \mathrm{~h}$ (Figure 12). P38 reached baseline levels at $2 \mathrm{~h}$ at $39^{\circ} \mathrm{C}$ but remained slightly elevated in hypothermia. Hypothermia also increased and prolonged the activation of $p 38$. There was no effect of temperature on $15 \mathrm{~min}$; but at $30 \mathrm{~min}, 45 \mathrm{~min}, 1 \mathrm{~h}$ and $2 \mathrm{~h}, \mathrm{p} 38$ was stronger and longer activated at $32^{\circ} \mathrm{C}$ than at $39^{\circ} \mathrm{C}$. The activation of $p 38$ reached baseline 
levels at $39^{\circ} \mathrm{C}$ after $45 \mathrm{~min}$, whereas p38 remained active at the $2 \mathrm{~h}$ time point at $32^{\circ} \mathrm{C}$.

\section{Activation of JNK of the MAPK-pathway}

Figure 12 outlines the activation of $\mathrm{JNK}$ over time. at $39^{\circ} \mathrm{C}$, JNK activation peaked at $15 \mathrm{~min}$ followed by decay in activation and the baseline was reached after $45 \mathrm{~min}$, very comparable to $\mathrm{p} 38$. This is in contrast to $\mathrm{JNK}$-activation at $32^{\circ} \mathrm{C}$. The peak activation was recorded at $30 \mathrm{~min}$ instead of $15 \mathrm{~min}$ resulting again in an increased and prolonged activation in hypothermia. Similarly to p38, there was no effect of temperature on the activation at $15 \mathrm{~min}$ and at $2 \mathrm{~h}$. JNK remained slightly activated at $2 \mathrm{~h}$ in hypothermia.

\section{Activation of Erk of the MAPK-pathway}

While the activation of NF-KB, p38 and JNK of the MAPK-pathway was comparable with increased and prolonged activation under hypothermic conditions, Erk-activation is different (Figure 13). The peak activation at $39^{\circ} \mathrm{C}$ was at $15 \mathrm{~min}$ followed by a gradual decrease. The baseline was reached after $1 \mathrm{~h}$. The peak activation of Erk at $32^{\circ} \mathrm{C}$ never reached the same level as at $39^{\circ} \mathrm{C}$. There was a clear activation at $15 \mathrm{~min}$, but it plateaued after $30 \mathrm{~min}$ and remained elevated in comparison with $39^{\circ} \mathrm{C}$ at $30 \mathrm{~min}, 45 \mathrm{~min}$ and $1 \mathrm{~h}$. The baseline was reached after $2 \mathrm{~h}$ in both temperatures. 
Figure 12: Activation of the NF-kB, p38 and JNK
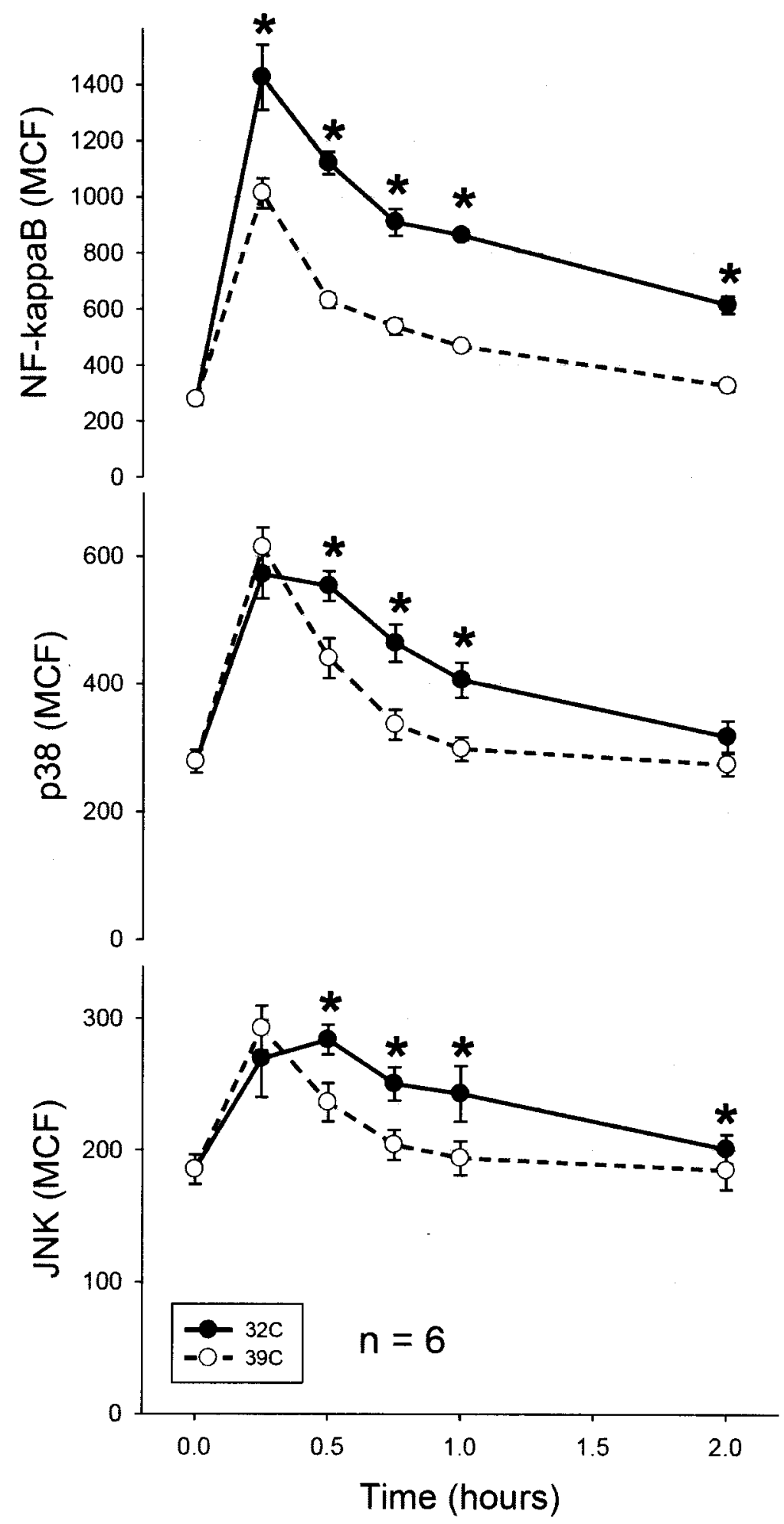


\section{Legend Figure 12}

Hypothermia has the strongest effect on NF-KB activation. The increase in activation at $32^{\circ} \mathrm{C}$ is five-fold and remains 2.2 -fold increased $2 \mathrm{~h}$ after initial stimulation.

The peak activation is not influenced by temperature. Hypothermia prolongs the activation of $p 38$.

JNK is the only pathway reaching peak activation at $30 \mathrm{~min}$ at $32^{\circ} \mathrm{C}$ but is also prolonged and increased activated.

MCF: Mean Channel Fluorescence

* indicates $p<0.05$; data are presented as mean \pm SEM 
Figure 13: Activation of Erk of the MAPK-pathway

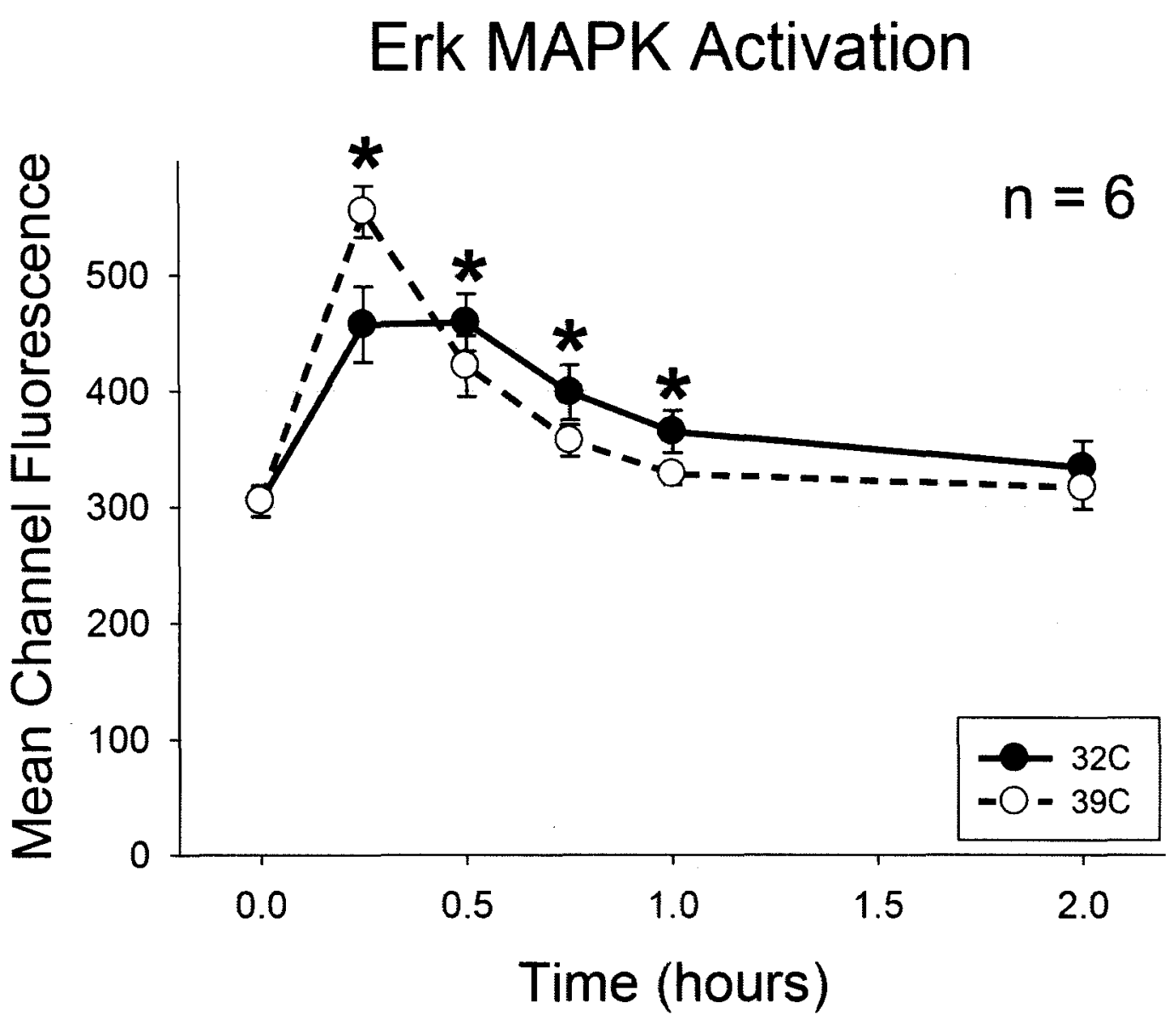

Erk is the only pathway which was activated to a higher level at $39^{\circ} \mathrm{C}$ than under hypothermic conditions.

* indicates $p<0.05$; data are presented as mean \pm SEM 


\section{DISCUSSION}

The activation of inflammatory signaling pathways is an important step in monocyte response and in the initiation and orchestration of the immune response. Our data demonstrate that hypothermia increases and prolongs the activation of pro-inflammatory signaling pathways, namely NF-KB, p38 and JNK, over the whole $2 \mathrm{~h}$ investigation period. This is in line with results from Fairchild et al. $(19,23)$. In contrast, the degree of activation of Erk is higher at $39^{\circ} \mathrm{C}$ at $15 \mathrm{~min}$ and this level of activation is not reached at $32^{\circ} \mathrm{C}$. However, Erk activation remains prolonged and increased after $30 \mathrm{~min}-1 \mathrm{~h}$ in hypothermia as it is the case with the three other pathways.

The exact biologic effect of these differences in pathway activation is difficult to assess. All of these pathways induce the production of proinflammatory cytokines such as TNF- $\alpha$, IL-6 and others $(109,126,190)$. NF-KB binds promoter sites of several pro-inflammatory cytokines resulting in their production. In addition, NF-KB increases cell survival and proliferation. P38 and JNK also induce the production of pro-inflammatory cytokines, but they can induce apoptosis as well as growth and differentiation of the cell. The Erkpathway is proposed to be more involved in control of growth and differentiation of cells than production of inflammatory cytokines. However, Erk contributes significantly to the production of pro-inflammatory cytokines in monocytes $(126,190)$. Other data suggests that the Erk-pathway is pivotal in the initiation and also the amount of IL-10 production (99). The regulation of IL-10 is a complex process and the ability to produce as well as the mechanisms leading to 
IL-10 production varies even among closely related cells such as monocytes, macrophages and dendritic cells. The available data so far suggest that Erk is a central regulator of IL-10 production. However, NF-KB is also able to initiate the production of IL-10 but only after stimulation of the TLR-receptor.

Some of the actions are obviously contradictory and the end result of the pathway activation depends upon complex interactions between different pathways and also the transcription factors they activate and the genes they express. These data also suggest that the production of pro-inflammatory cytokines and therefore the ability to respond to trauma and inflammation is highly redundant. The knock-out of some of the MAPK-proteins does not result in reduced production of pro-inflammatory cytokines whereas knock-out mice for p38 or NF-kB were not viable (191).

Applying this information to our results, the increased and prolonged activation of NF-KB, p38 and JNK in hypothermia would explain the prolonged secretion of TNF- $\alpha$ and IL- 6 in our model. The more distinct difference in IL-10 production is more difficult to explain. We believe that the increased activation of Erk at $15 \mathrm{~min}$ at $39^{\circ} \mathrm{C}$ is responsible or contributes significantly to the production of IL-10. The fact that Erk-activation at $32^{\circ} \mathrm{C}$ never reaches comparable levels than at $39^{\circ} \mathrm{C}$ would fit well into our explanation because Kaiser et al. demonstrated that the degree of Erk activation correlates with the degree of IL-10 production (192). 
The next step after identification of these significant differences in pathway activation is to determine if the increased and prolonged activation of the proinflammatory signaling pathways result in differences in gene expression. We propose that the prolonged activation of NF-KB, p38 and JNK results in a prolonged production of pro-inflammatory cytokine genes as well as proinflammatory microRNAs. The higher degree of Erk-activation should result in a high degree of IL-10 gene expression. 


\section{CHAPTER VI}

\section{INFLUENCE OF TEMPERATURE ON EXPRESSON OF CYTOKINE GENES AND MICRORNA - 155}

Activated signaling pathways activate transcription factors which initiate the transcription of genes with the appropriate promoter sequence. The three different arms of the MAPK-pathway are able to activate several different transcription factor or different subunits, which then associate with each other in order to induce gene transcription. NF-KB itself is a transcription factor and induces gene expression independently without the use of other transcription factors. In the previous experiment we found a profound impact of temperature on activation of both the NF-KB and MAPK-pathway. Hypothermia increased and prolonged the activation of NF-KB, p38 and JNK, whereas the peak activation of Erk was diminished but still prolonged. Consequently, we determined if these differences result in increased expression of mRNA of target genes of these pathways such as TNF- $\alpha$ and $\mathrm{IL}-10$ and if temperature demonstrates the expected effect.

MicroRNAs are also transcribed like cytokine genes from DNA to RNA and also depend upon the activation of transcription factors. MiRNA-155 expression is induced by NF-kB $(149,193)$. Furthermore, the MAPK-pathway has also been implicated in the induction of miRNA-155 (194-196). 
Therefore, the increased and prolonged activation of both signaling pathways should also have an effect on the expression of miRNA-155. We hypothesize that miRNA-155 is increased and has prolonged expression in hypothermia.

Furthermore, a significant effect of temperature on miRNA-155 may also result in expression changes of the miRNA-155 target, SHIP-1.

\section{RESULTS}

\section{Effect of Temperature on Cytokine-Gene Expression}

Expression of mRNA precedes the production and secretion of proteins.

Therefore, we chose to investigate earlier time points for this experiment than for the protein secretion. We found that the induction of TNF- $\alpha$ mRNA occured quickly within $3 \mathrm{~h}$ after LPS stimulation at both temperatures (Figure 14). The mRNA-expression of TNF- $\alpha$ peaked at $39^{\circ} \mathrm{C}$ at $6 \mathrm{~h}$ with a 22 -fold increase followed by a steep drop to a 2.5 fold increase compared with baseline. Unlike $39^{\circ} \mathrm{C}$, TNF- $\alpha$ mRNA expression increased over the whole observation period in hypothermia reaching comparable levels of fold change.

Our observation show that the induction of $\mathrm{IL}-10 \mathrm{mRNA}$ begins at $3 \mathrm{~h}$ and peaks between $12 \mathrm{~h}$ and $24 \mathrm{~h}$ in both temperatures (Figure 14). The fold-change of IL-10 mRNA in general was much higher compared to TNF- $\alpha$, but was again higher at $39^{\circ} \mathrm{C}$ than at $32^{\circ} \mathrm{C}$. The peak fold change at $39^{\circ} \mathrm{C}$ was $>1100$ fold at $12 \mathrm{~h}$, whereas $32^{\circ} \mathrm{C}$ reached $133-$ fold at the same time. The peak induction in 
hypothermia appeared to be at $24 \mathrm{~h}$. The differences in IL-10 mRNA expression are significant between the two temperatures at $3 \mathrm{~h}, 6 \mathrm{~h}$ and $12 \mathrm{~h}$.

These changes in mRNA-expression in TNF- $\alpha$ and $\mathrm{IL}-10$ are likely to be responsible for the observed differences in secreted TNF- $\alpha$ and IL-10. The prolonged up-regulation of TNF- $\alpha$ mRNA at $12 \mathrm{~h}$ and $24 \mathrm{~h}$ results in an increased production of TNF- $\alpha$ protein at $32^{\circ} \mathrm{C}$ at $24 \mathrm{~h}$ and $36 \mathrm{~h}$ (Figure 11). Conversely, the strong up-regulation of IL-10 mRNA starting at $3 \mathrm{~h}$ is translated into IL-10 protein and secreted starting at $6 \mathrm{~h}$ at $39^{\circ} \mathrm{C}$. Although the up-regulation of IL-10 mRNA at $32^{\circ} \mathrm{C}$ is less pronounced than at $39^{\circ} \mathrm{C}$, the difference in secreted $\mathrm{IL}-10$ protein is much larger than the difference in gene expression would suggest. This discrepancy may be explained by additional mechanisms such as translational inhibition or an inhibition of IL-10 protein secretion.

\section{Effect of Temperature on miRNA-155 Expression}

The expression of miRNA-155 over time is shown in Figure 15. Similar to the cytokines, miRNA-155 expression was induced early and a 10-fold upregulation can be observed at $6 \mathrm{~h}$ in both temperatures. The peak expression in both temperatures occurred at $12 \mathrm{~h}$. MiRNA-155 remains up-regulated on a higher level, about 20 -fold, in hypothermia at $24 \mathrm{~h}$ and $36 \mathrm{~h}$, whereas the expression decreased to levels below 10 -fold at $39^{\circ} \mathrm{C}$. The expression difference at $24 \mathrm{~h}$ and $36 \mathrm{~h}$ was significant between $32^{\circ} \mathrm{C}$ and $39^{\circ} \mathrm{C}$. 


\section{Effect of Temperature and miRNA-155 on SHIP-1 Expression}

The expression of SHIP-1 is shown in Figure 16. SHIP-1 mRNA is downregulated over the $36 \mathrm{~h}$ of the study period. At $6 \mathrm{~h}$ and $12 \mathrm{~h}$, SHIP-1 mRNA is stronger down-regulated at $39^{\circ} \mathrm{C}$. At the later time points, at $24 \mathrm{~h}$ and $36 \mathrm{~h}, \mathrm{SHIP}-1$ mRNA remains down-regulated at $32^{\circ} \mathrm{C}$ the amount of down-regulations decreases at $39^{\circ} \mathrm{C}$. The differences between the two temperatures are significant at all time points except at $12 \mathrm{~h}$. 
Figure 14: Expression of TNF- $\alpha$ and $I L-10$ mRNA at $32^{\circ} \mathrm{C}$ and $39^{\circ} \mathrm{C}$
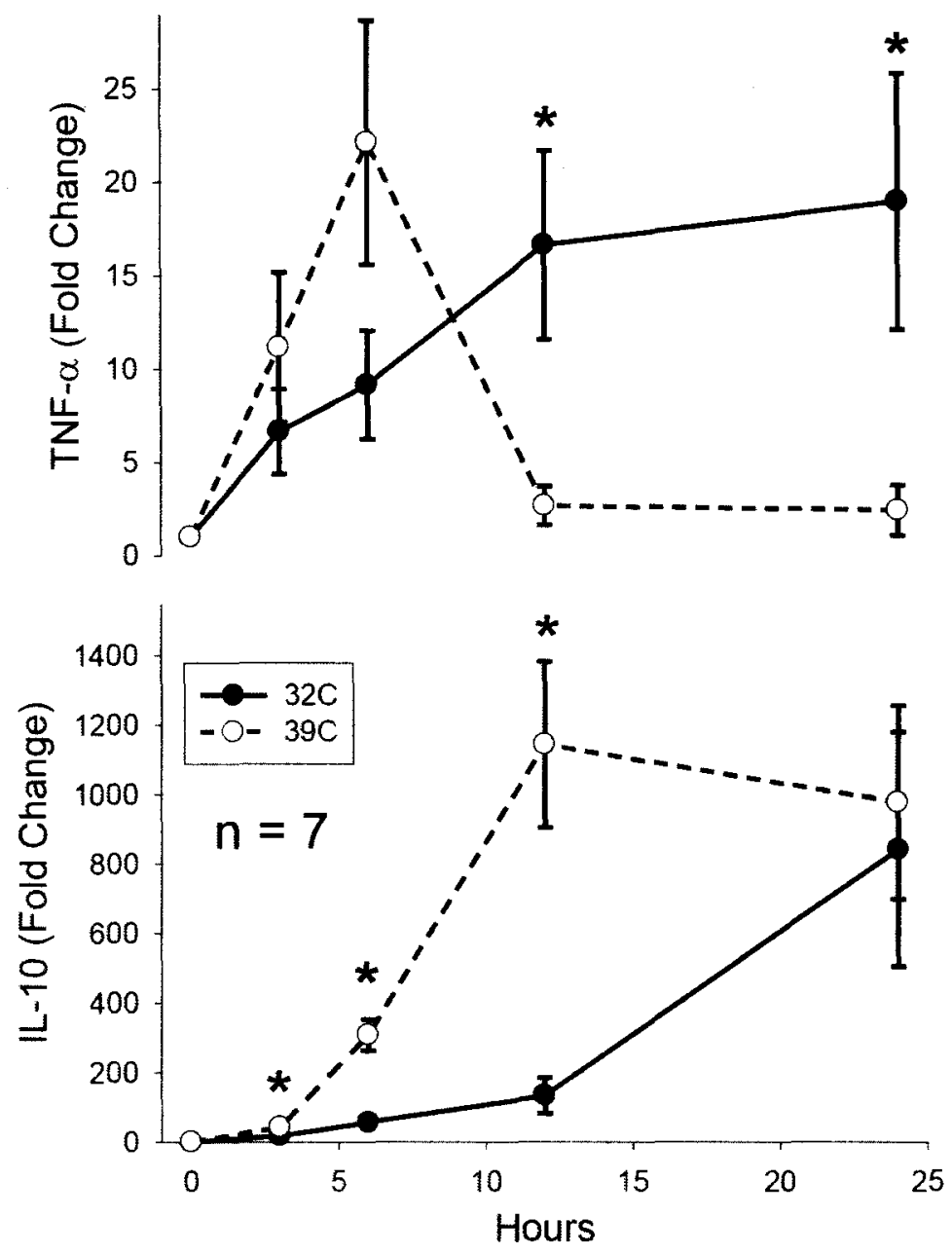

The induction of TNF-a mRNA was more rapid but less pronounced at $39^{\circ} \mathrm{C}$; the $32^{\circ} \mathrm{C}$ TNF- $\alpha$ mRNA is consistently and increasingly up-regulated within the first 24h. IL-10 mRNA is strongly induced within $3 \mathrm{~h}$ at $39^{\circ} \mathrm{C}$. The IL-10 up-regulation in hypothermia is delayed but ultimately reaches comparable levels at $24 \mathrm{~h}$. Of note, the degree of IL-10 mRNA up-regulation was high in both temperatures.

* indicates $p<0.05$; data are presented as mean \pm SEM 
Figure 15: Expression of miRNA- 155 at $32^{\circ} \mathrm{C}$ and $39^{\circ} \mathrm{C}$

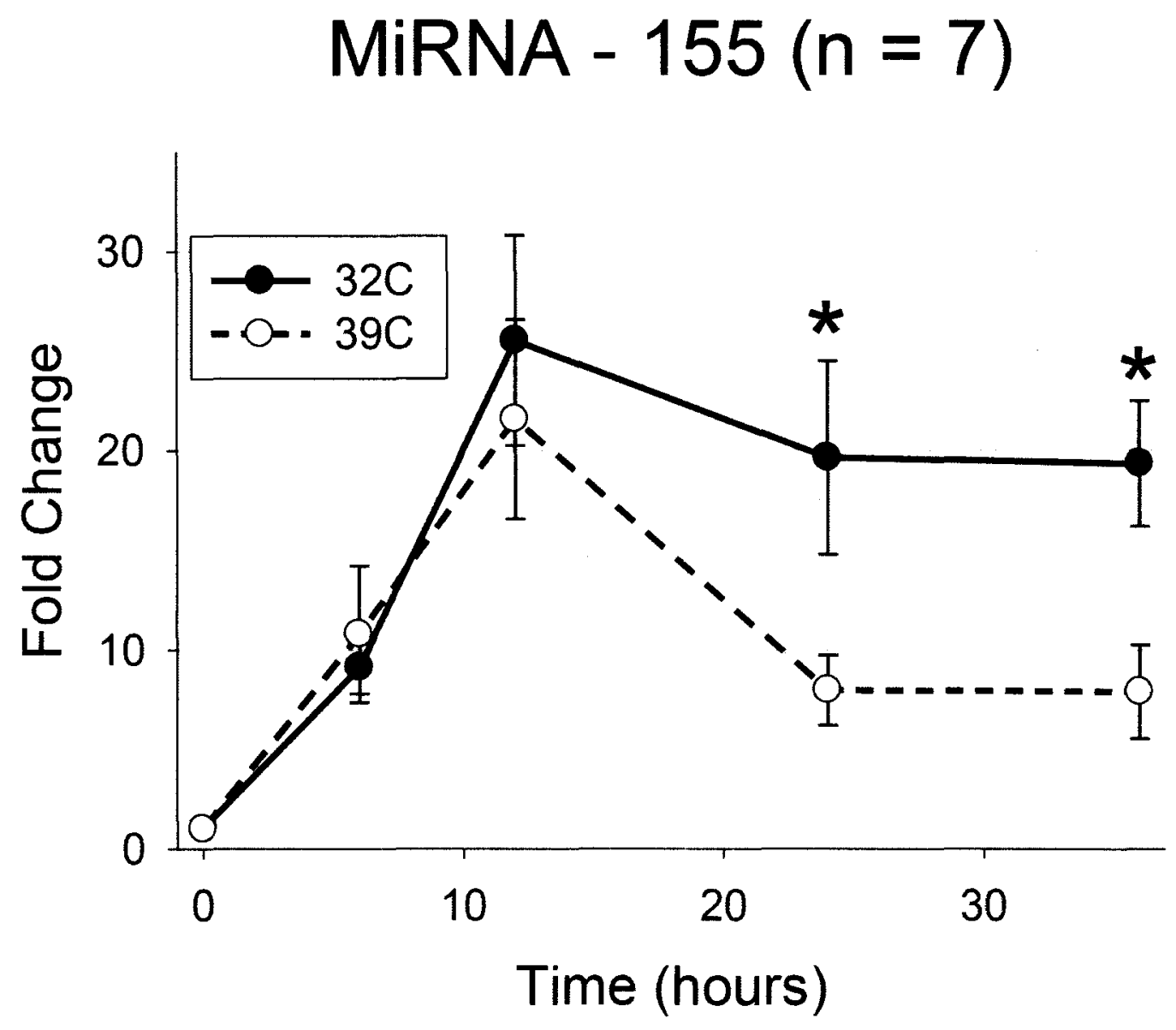

The expression changes in miRNA-155 parallel changes in TNF- $\alpha$ mRNA. The impact of temperature occurred at later time points (24h and $36 \mathrm{~h}$ ).

* indicates $p<0.05$; data are presented as mean \pm SEM 
Figure 16: Expression of SHIP-1 mRNA at $32^{\circ} \mathrm{C}$ and $39^{\circ} \mathrm{C}$
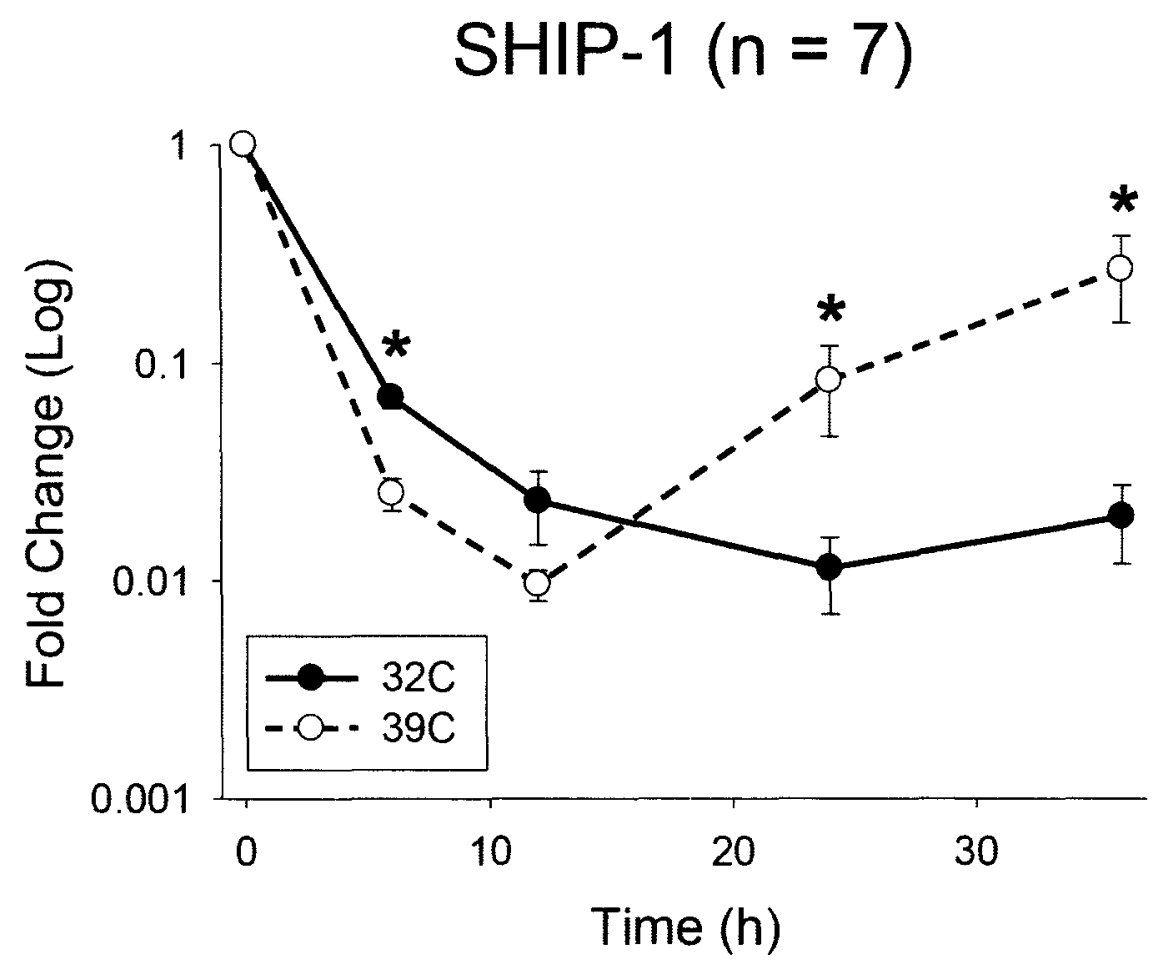

SHIP-1 mRNA is initially stronger down-regulation at $39^{\circ} \mathrm{C}$ followed by an upregulation compared to $32^{\circ} \mathrm{C}$. The down-regulation of SHIP-1 allows a stronger activation of the TLR-pathway leading to an increased secretion of proinflammatory cytokines. These expression changes explain the initially higher levels of TNF- $\alpha$ and $I L-6$ at $39^{\circ} \mathrm{C}$ but also the prolonged and increased secretion of TNF-a/L-6 at $32^{\circ} \mathrm{C}$. Furthermore, these results are concurrent with the expression changes of miRNA-155 of which SHIP-1 is a target. The higher miRNA-155 levels in hypothermia at $24 \mathrm{~h}$ and $36 \mathrm{~h}$ correlate with a stronger suppression of SHIP-1 mRNA at $32^{\circ} \mathrm{C}$ at these two time points.

${ }^{*}$ indicates $p<0.05$; data are presented as mean \pm SEM 


\section{DISCUSSION}

The induction of gene expression is the presumed next step in the monocyte response to an infection after activation of the signaling pathways. Gene expression serves several purposes. First, after the secretion of preformed cytokines during the immediate response, new cytokines have to be produced in order to replenish the secreted cytokines but also to maintain the communication between immune cells and orchestration of the immune response. Second, the inhibition and modulation of the initial pathway activation has to be induced. For this purpose, phosphatases are induced, which de-phosphorylate the activated proteins of the TLR-signaling complex such as IRAK-1/2 and TRAF-6. SHIP-1 and SOCS-1 are two such examples of these up-stream inhibitors of the TLRsignaling pathway $(119,120,145)$. In addition, the down-stream signaling pathways are also inhibited by phosphates. Especially the MAPK-pathway is highly regulated by inhibitors such as the DUSP's (127-129). Besides the inhibition of the signaling process, fine-tuned production of inhibitors allows also the modulation of the response by selective inactivation of one or several arms of the MAPK-pathway. Lastly, the pathway proteins are also reproduced and the expression of some of these pathways can change upon cell activation in order to maintain or diminish the response to the infection.

We investigated the expression of cytokine genes in order to determine if the reported differences in pathway activation result in differences in gene expression. We found that TNF- $\alpha$ is increased and has prolonged expression at $32^{\circ} \mathrm{C}$; this can be explained by the prolonged activation of the pro-inflammatory 
signaling pathways. Moreover, the sustained up-regulation of TNF- $\alpha$ mRNA at $12 \mathrm{~h}$ and $24 \mathrm{~h}$ correlates with the prolonged secretion of TNF- $\alpha$ protein at $24 \mathrm{~h}$ and $36 \mathrm{~h}$. at $39^{\circ} \mathrm{C}$, the induction of $\mathrm{IL}-10 \mathrm{mRNA}$ is stronger and higher than under hypothermic conditions. We believe that the higher degree of Erk activation is responsible or contributes strongly to this observation. The IL-10 mRNA upregulation correlates with the high $\mathrm{IL}-10$ levels measured at $39^{\circ} \mathrm{C}$. Although the $\mathrm{IL}-10 \mathrm{mRNA}$ induction is not as pronounced in hypothermia as at $39^{\circ} \mathrm{C}$, there is still a much stronger up-regulation of IL-10 mRNA (>800-fold) at $32^{\circ} \mathrm{C}$ compared to TNF- $\alpha$ (20-fold) indicating inhibition of IL-10 protein production and/or modulation of IL-10 protein secretion.

Besides the cytokine mRNA, miRNA-155 is also prolonged expressed in hypothermia. Since the expression of miRNA-155 is controlled by NF-KB and probably also by $\mathrm{p} 38$ and $\mathrm{JNK}$, the prolonged activation of these pathways is the likely cause of the increased and prolonged expression of miRNA-155 in hypothermia. Furthermore, the temperature related differences in miRNA-155 expression may explain the observed increased and prolonged secretion of TNFa protein at $32^{\circ} \mathrm{C}$. MiRNA-155 was one of the first microRNAs, which was shown to respond to inflammatory stimuli (196). Early on, an association with TNF-a was observed. The causal link between increased miRNA-155 and increased TNF- $\alpha$ was subsequently demonstrated by several groups $(139,145,147)$. However, miRNA-155 has also been shown to have anti-inflammatory properties by inhibiting the expression of MyD88, the central signaling protein of TLR-4, and TAB2, an important signaling molecule of the NF-KB and MAPK-pathway 
$(140,148)$. While the pro-inflammatory effect of miRNA-155 with an increase in TNF- $\alpha$ production can be observed within 24h, the suppressive effect on MyD88 requires at least $48 \mathrm{~h}-72 \mathrm{~h}$ to be effective. Therefore, the timing of miRNA-155 expression is pivotal in order to determine the biologic effect.

SHIP-1 is one of the main targets by which miRNA-155 increases the production of pro-inflammatory cytokines $(139,145,197)$. As expected, SHIP-1 mRNA is strongly down-regulated upon activation of the TLR-pathway. At 6 , the down-regulation of SHIP-1 is stronger at $39^{\circ} \mathrm{C}$ correlating with increased secretion of TNF- $\alpha$ and IL-6; the pro-longed and strong down-regulation of SHIP$1 \mathrm{mRNA}$ at $32^{\circ} \mathrm{C}$ at $24 \mathrm{~h}$ and $36 \mathrm{~h}$ explains also the prolonged and increased levels of TNF- $\alpha$ and IL- 6 in hypothermia. Furthermore, the differences in SHIP-1 mRNA between $32^{\circ} \mathrm{C}$ and $39^{\circ} \mathrm{C}$ correlate with the expression changes of miRNA155 indicative of a miRNA-155 induced degradation of SHIP-1 mRNA. The increased expression of miRNA- 155 at $32^{\circ} \mathrm{C}$ lead to the degradation of SHIP-1 mRNA, whereas the decreased levels of miRNA-155 allow up-regulation of SHIP- 1 mRNA at $39^{\circ} \mathrm{C}$.

Based on these reports, we propose that the prolonged up-regulation of miRNA-155 is responsible for the prolonged TNF- $\alpha$ production in hypothermia (Figure 17). Increased and prolonged activation of NF-KB, p38 and JNK induces a strong expression of miRNA-155. The reduced expression of the two TLRpathway inhibitors SHIP-1 and SOCS -1 at $32^{\circ} \mathrm{C}$ increases pathway activation and results in prolonged production of TNF- $\alpha$ mRNA, which is then translated into TNF- $\alpha$ protein and secreted. 
Figure 17: The Increased and Prolonged miRNA-155 Expression Contributes to the Prolonged and Increased TNF- $\alpha$-Production

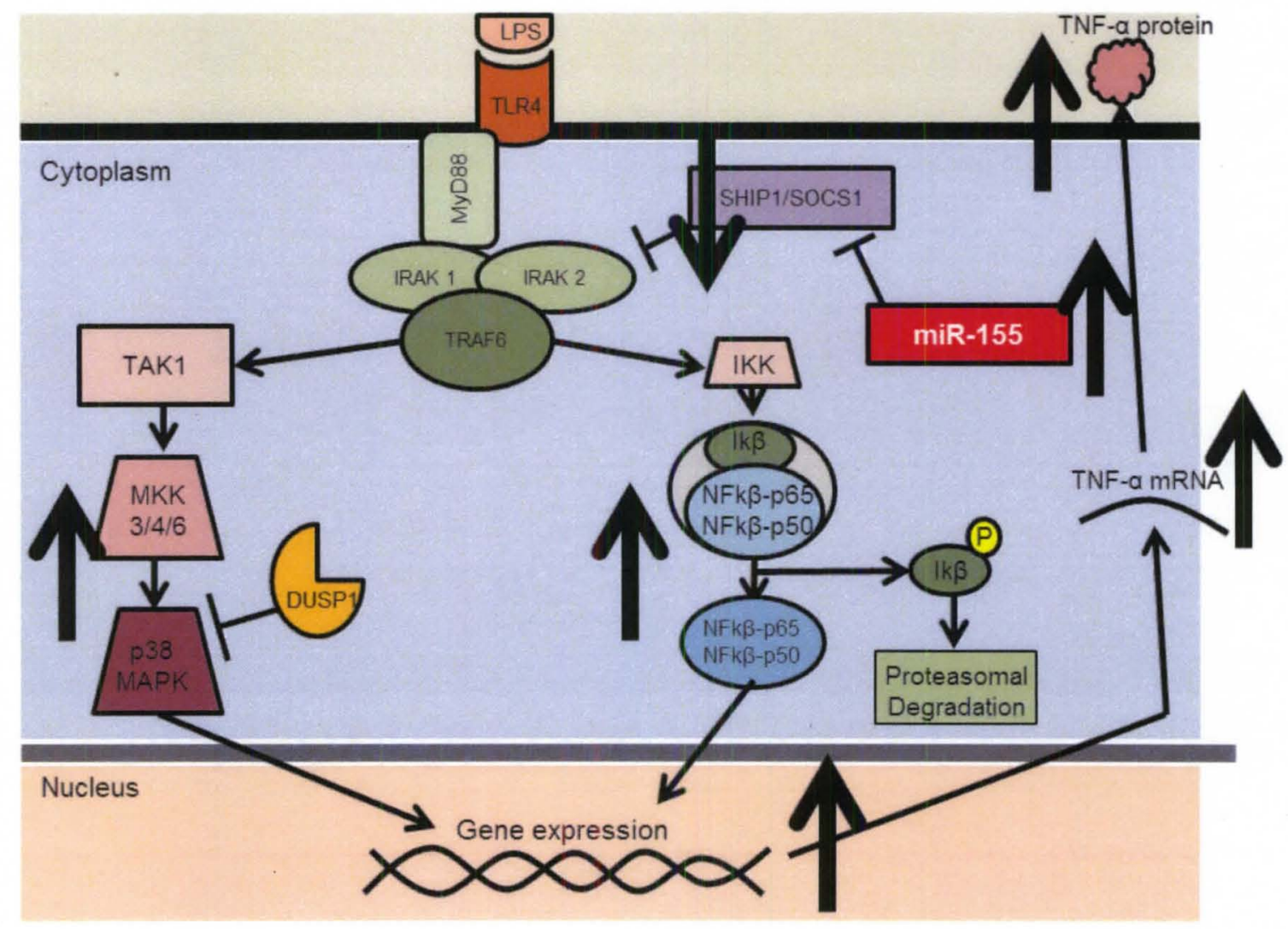

A prolonged up-regulation of the miRNA-155 results in a reduced expression of two TLR-4 inhibitors (SHIP-1/SOCS-1), which in turn increases and prolongs the activation of the TLR-4 signaling pathway including NF-KB and the MAPKpathway. The increased signaling of the TLR-4 pathway increases the production of pro-inflammatory cytokines such as TNF- $\alpha$ and IL-6, which then are translated into cytokine proteins. 


\section{CHAPTER VII}

\section{MiRNA-155 IS RESPONSIBLE FOR THE PROLONGED TNF- $\alpha$ SECRETION}

In previous experiments, we found prolonged elevated levels of miRNA155 in hypothermic conditions, which correlated with the prolonged expression of TNF- $\alpha$ mRNA and protein. Based on available literature we propose that the increased and prolonged expression of miRNA-155 is responsible for the sustained TNF-a production at $32^{\circ} \mathrm{C}$ (Figure 17). Two main targets of miRNA155, SHIP-1 and SOCS-1 are negative regulators of the TLR-4 signaling pathway $(139,145,149)$. An inhibition of the translation of SHIP-1 and SOCS-1 by miRNA155 increases the signaling of the TLR-4 pathway and results in a prolonged expression of TNF- $\alpha$ mRNA, which is subsequently translated into TNF- $\alpha$ protein and secreted. Our results show an expression change of SHIP-1 mRNA concurrent with an inhibitory effect of miRNA-155 at $32^{\circ} \mathrm{C}$ at $24 \mathrm{~h}$ and $36 \mathrm{~h}$.

However, miRNA-155 has also been shown to target other proteins such as MyD88 or TAB2, which results in an anti-inflammatory function for miRNA-155 $(140,148)$. The time course of our data suggests that miRNA-155 has probably pro-inflammatory functions in our results because the time needed for miRNA155 to develop anti-inflammatory properties is usually more than $24 \mathrm{~h}-48 \mathrm{~h}$. This can be explained by the targeted proteins: SHIP-1 and SOCS-1, the two proteins we propose as targets of miRNA-155 in our model, are newly expressed upon 
stimulation of the TLR-4 pathway, whereas MyD88 and TAB2 are already expressed. MicroRNAs can only inhibit the production of proteins and do not have any effect on already expressed proteins. Therefore, up-regulation of miRNA-155 will immediately inhibit the production of SHIP-1 and SOCS-1 and will also consequently have an immediate effect on the TLR-4 pathway, e.g. prolong its activation. This is in contrast to MyD88 and TAB2. Both proteins are pre-existing in the cell and without their presence, the activation of the TLR-4 pathway would be impaired. These pre-existing proteins are not immediately affected by up-regulation of miRNA-155. However, the re-expression of the proteins will be affected resulting in a slow decrease of MyD88 and TAB2. Ultimately, the reduced amount of these two proteins will diminish the signaling through the TLR-4 pathway. Taken these two actions together, it appears that miRNA-155 has a dual role; first as a pro-inflammatory microRNA but at the same time, it acts as a delayed inhibitor of the inflammatory response.

The purpose of the next experiment was to confirm the pro-inflammatory role of miRNA-155 in our experiments and that the prolonged expression of miRNA-155 in hypothermia is responsible for the prolonged TNF-a production. Furthermore, successful modulation of TNF- $\alpha$ secretion by manipulation of miRNA-155 expression might also offer potential therapeutic applications. For this purpose, we modulated the expression of miRNA-155 in the primary monocytes with microRNA-mimics and microRNA-antagomirs. 


\section{RESULTS}

\section{Over-expression and Suppression of miRNA-155}

The transfection of the primary monocytes was successfully accomplished. Figure 18 shows the miRNA-155 expression levels. The mimics strongly over-expressed miRNA-155 whereas the antagomirs suppressed miRNA-155 compared to the with negative control transfected monocytes. In average, the mimics resulted in a $>100$-fold up-regulation of miRNA-155 and the antagomirs reduced the expression about 3-fold. All of these changes were statistically significant.

\section{Effect of miRNA- 155 on TNF- $\alpha$ at $32^{\circ} \mathrm{C}$ and $39^{\circ} \mathrm{C}$}

The effect of miRNA-155 on TNF- $\alpha$ is outlined in Figure 19. Independent of the temperature, over-expression of miRNA-155 resulted in significantly increased levels of TNF- $\alpha$. The effect of miRNA-155 up-regulation seems to be more pronounced at $32^{\circ} \mathrm{C}$ than at $39^{\circ} \mathrm{C}$. Transfection with miRNA-155-mimics at $39^{\circ} \mathrm{C}$ increased TNF- $\alpha$ to higher levels as in the negative control transfected cells at $32^{\circ} \mathrm{C}$. It is therefore possible to make " $39^{\circ} \mathrm{C}$ look like $32^{\circ} \mathrm{C}$ ".

The suppression of miRNA-155 expression had only a significant effect on TNF- $\alpha$ levels at $32^{\circ} \mathrm{C}$. Suppression of miRNA-155 expression reduced TNF- $a$ to slightly lower levels than the negative control at $39^{\circ} \mathrm{C}$. Thus, suppression of 
miRNA-155 "makes $32^{\circ} \mathrm{C}$ look like $39^{\circ} \mathrm{C}$ ". A further knock-down of miRNA-155 expression at $39^{\circ} \mathrm{C}$ did not translate into significantly lower TNF- $\alpha$ levels.

\section{Effect of miRNA-155 on IL-6}

The effects of modulation of the expression of miRNA-155 on IL- 6 are shown in Figure 20. The changes of IL-6 expression changes were similar to the one observed in TNF-a. The over-expression as well as the suppression of miRNA-155 in the monocytes in both temperatures had a significant effect on IL6 expression, similarly to the effects observed in TNF- $\alpha$. In addition, suppression of miRNA-155 expression had significant effect on IL-6.

\section{Effect of miRNA-155 on IL-10}

Manipulation of miRNA-155 expression did not affect the IL-10 levels consistently (Figure 21). Suppression of miRNA-155 at $39^{\circ} \mathrm{C}$ reduced IL-10 levels significantly. However, at $32^{\circ} \mathrm{C}$, there was a trend to higher IL-10 levels in the antagomir-transfected monocytes. However, these effects were not consistent among the different donors. 


\section{Effect of miRNA-155 on SHIP-1 mRNA}

Over-expression of miRNA-155 significantly reduced the expression of SHIP-1 mRNA whereas suppression of miRNA-155 expression increased SHIP-1 mRNA (Figure 22). 
Figure 18: Successful Over-expression and Suppression of miRNA-155

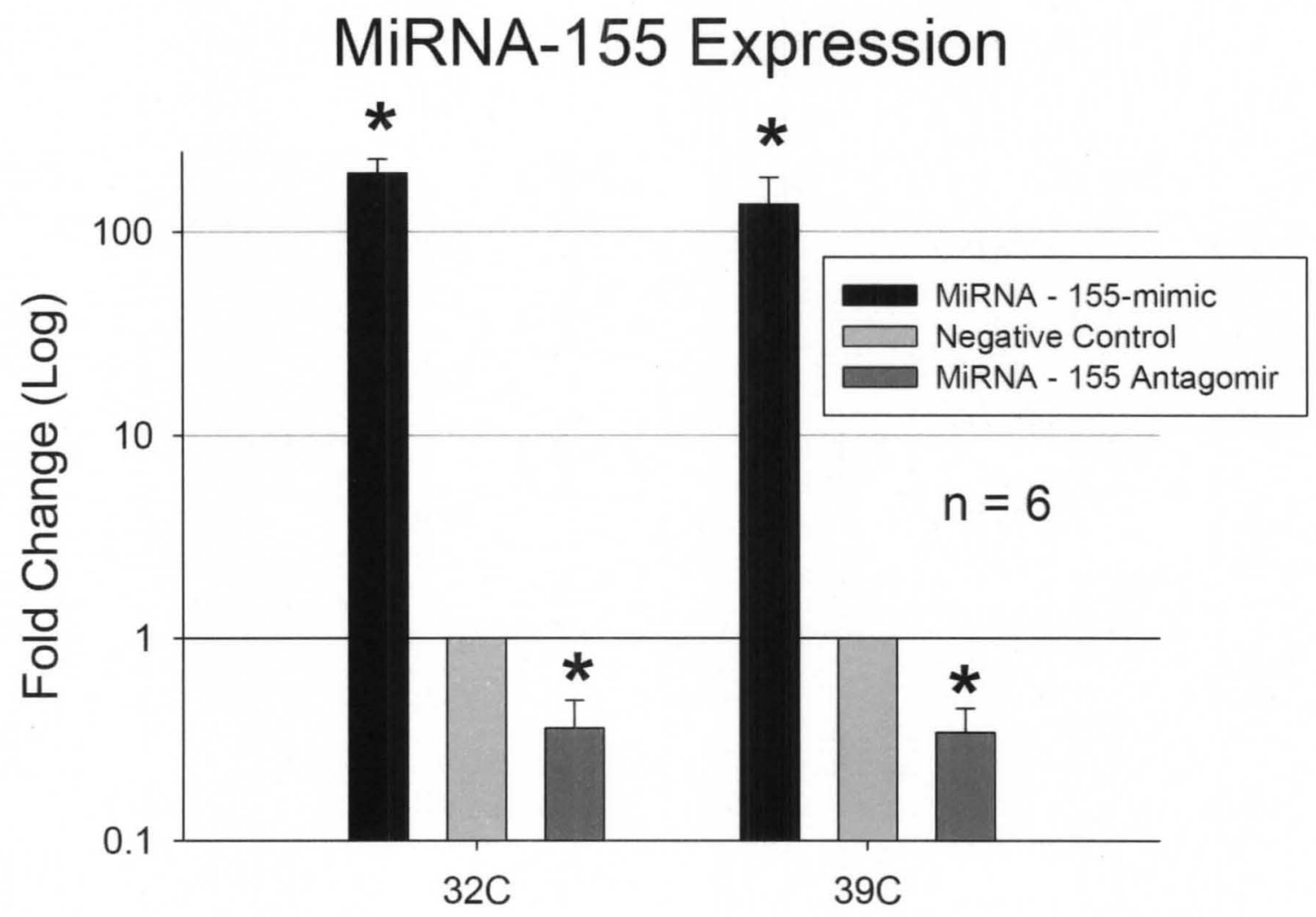

Transfection with miRNA-155-mimic led to a significant over-expression of miRNA-155 in both temperatures. Similarly, the use of antagomirs suppressed the expression of miRNA-155 in both temperatures. Note the logarithmic scale of the fold change.

* indicates $p<0.05$; data are presented as mean \pm SEM 
Figure 19: Effect of miRNA-155 on TNF- $\alpha$

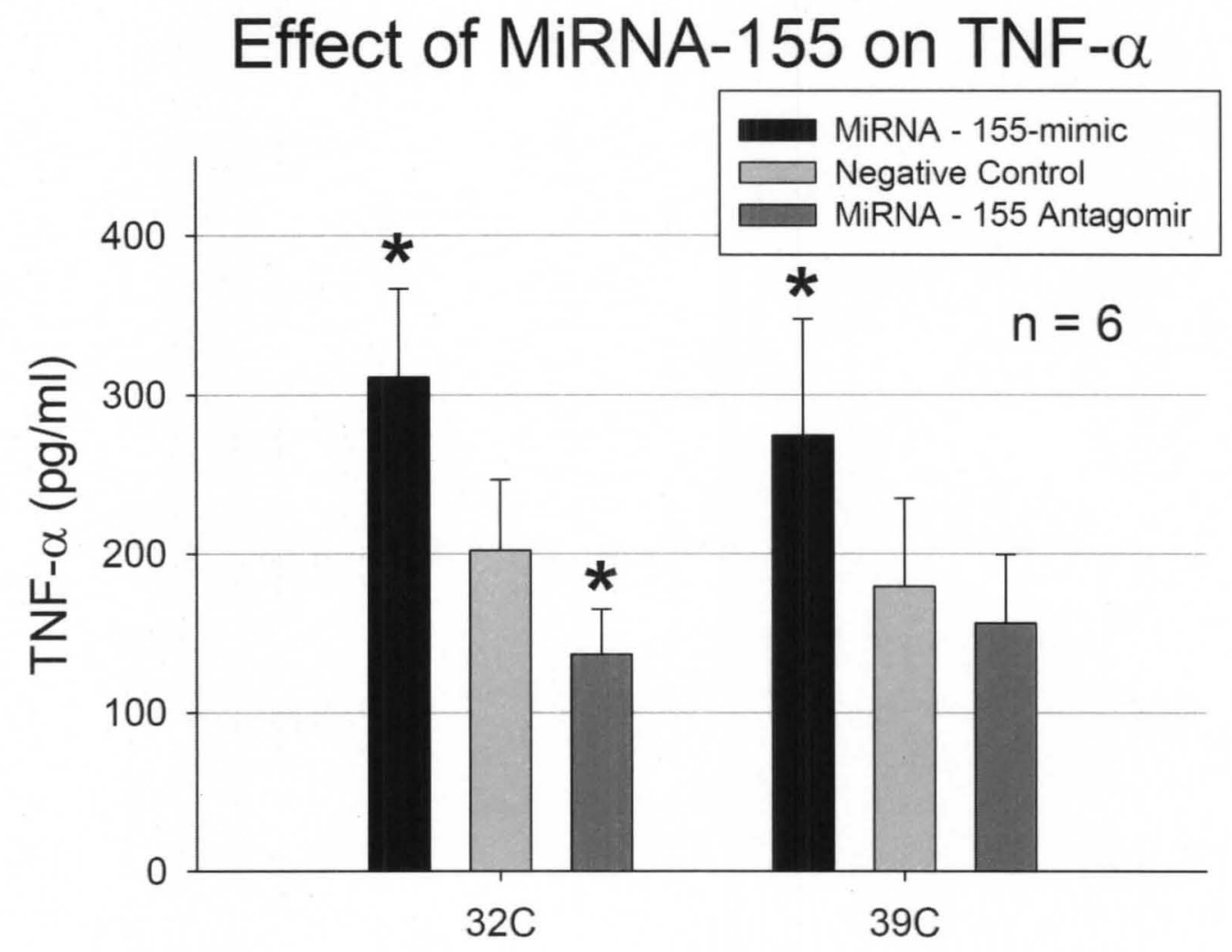

Manipulation of miRNA-155 expression showed the expected results. Overexpression of miRNA-155 increased TNF- $\alpha$ at $32^{\circ} \mathrm{C}$ and $39^{\circ} \mathrm{C}$ whereas the suppression only significantly reduced the expression of TNF- $\alpha$ at $32^{\circ} \mathrm{C}$.

* indicates $p<0.05$; data are presented as mean \pm SEM 
Figure 20: Effect of miRNA-155 on IL-6

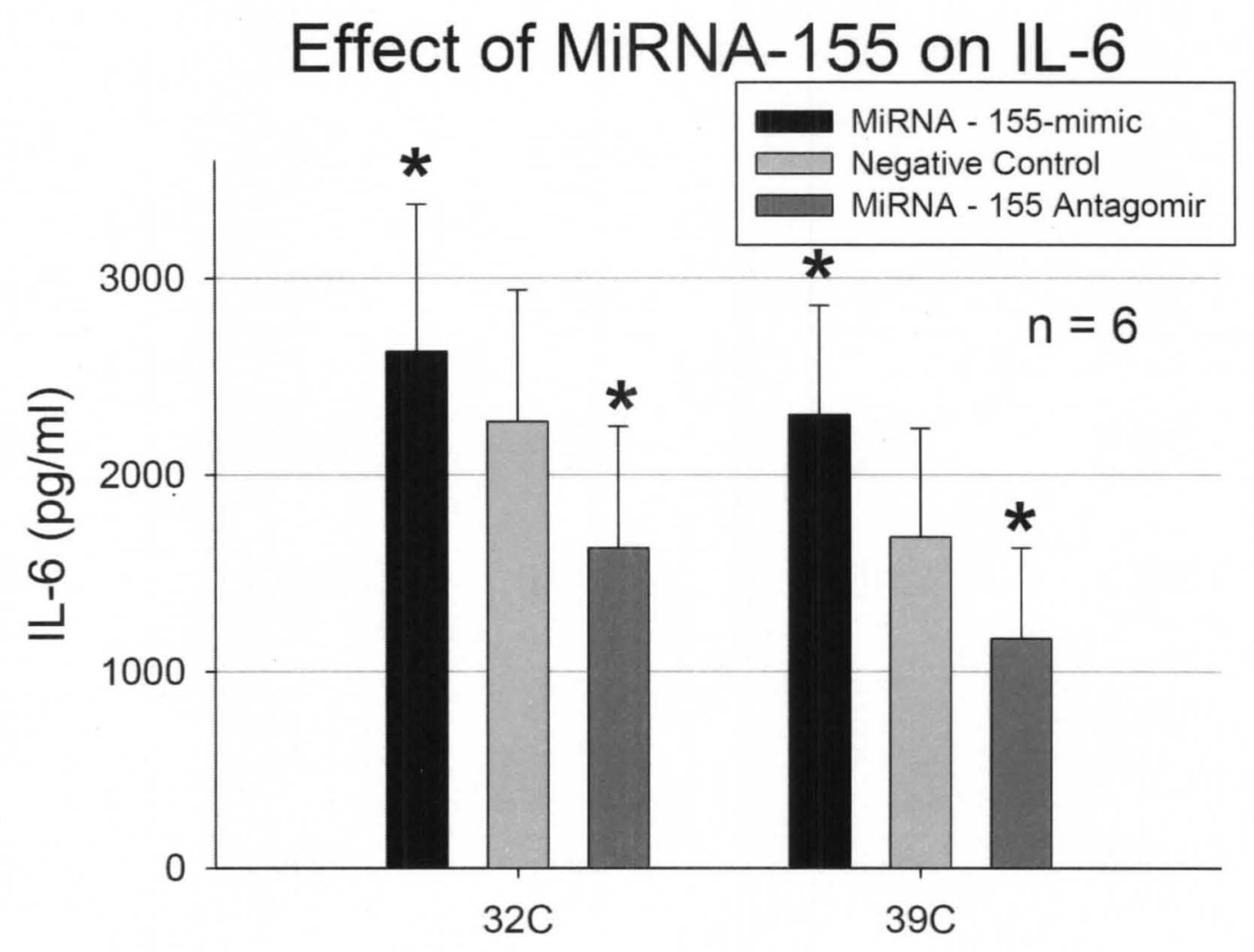

Modulation of miRNA-155 expression had a significant effect on IL-6 in both temperatures similarly to TNF- $\alpha$. In addition, suppression of miRNA-155 at $39^{\circ} \mathrm{C}$ reduced IL-6 expression significantly.

* indicates $p<0.05$; data are presented as mean \pm SEM 
Figure 21: Effect of miRNA-155 on IL-10

\section{Effect of MiRNA-155 on Interleukin-10}

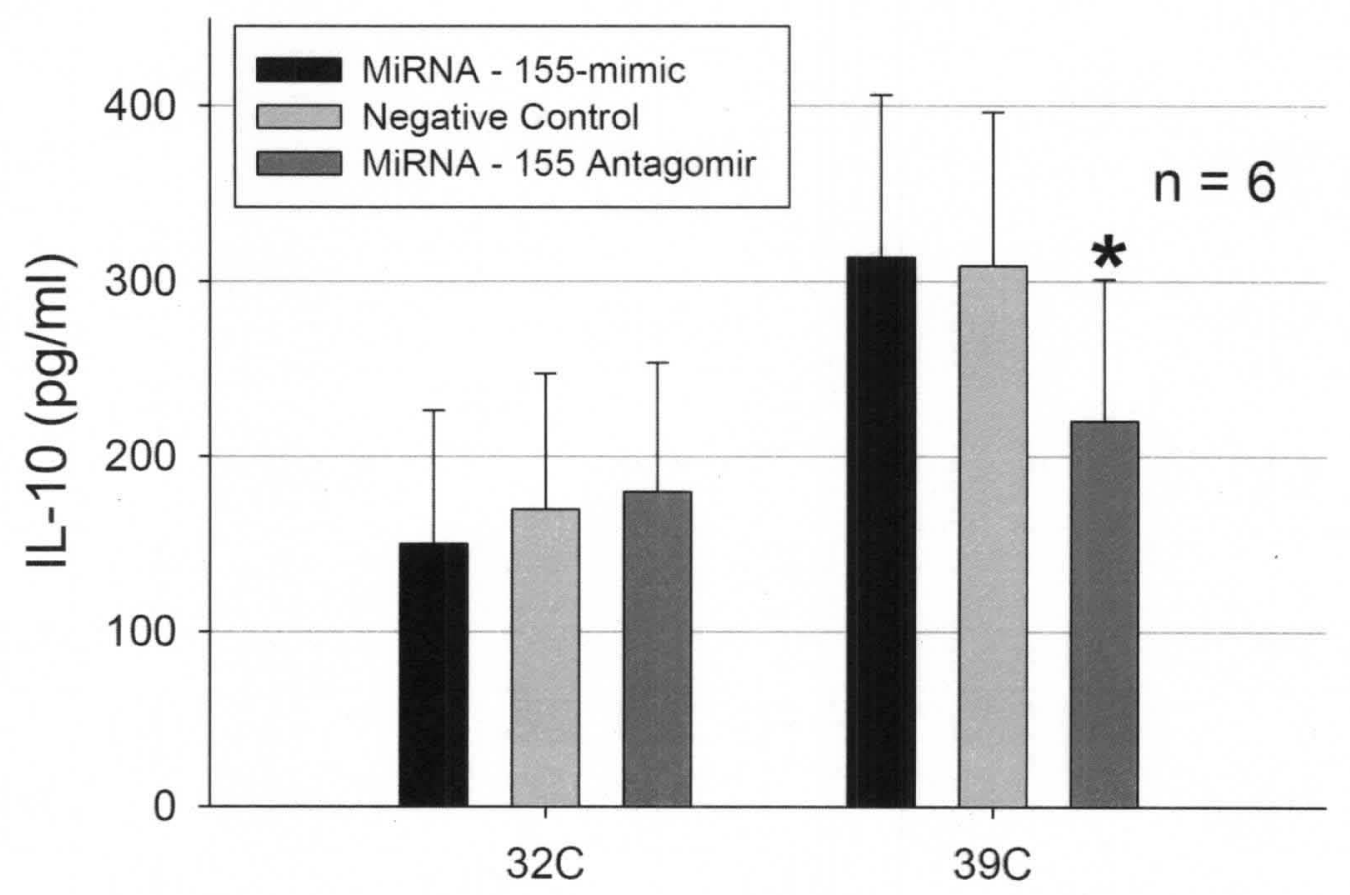

Only suppression of miRNA-155 at $39^{\circ} \mathrm{C}$ had a significant effect on IL-10.

* indicates $p<0.05$; data are presented as mean \pm SEM 
Figure 22: Effect of miRNA-155 on SHIP-1 mRNA

\section{SHIP-1 Expression}

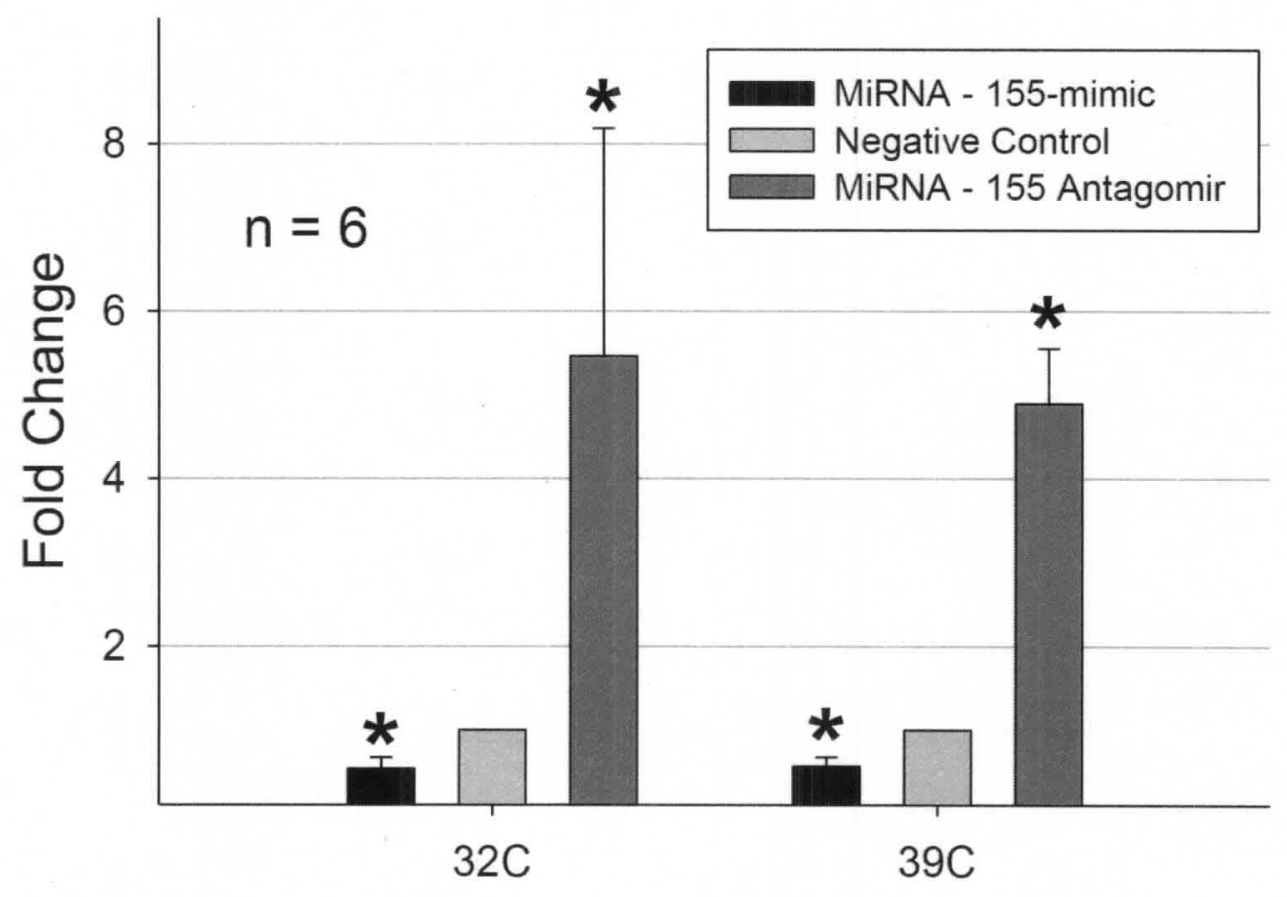

Over-expression of miRNA-155 suppresses SHIP-1 mRNA expression. A reduction of miRNA-155 expression increases the expression of SHIP-1 mRNA.

${ }^{*}$ indicates $p<0.05$; data are presented as mean \pm SEM 


\section{DISCUSSION}

MiRNA-155 can have both pro- and anti-inflammatory effects during the monocyte response depending on the target and the time since the stimulation. Initially, miRNA-155 has pro-inflammatory properties and increases the activation of the TLR-4 pathway including the NF-KB and MAPK pathways. This effect is due to the inhibition of production of SHIP-1 and SOCS-1; both proteins inhibit the TLR-4 signaling complex upstream. We found expression changes of SHIP-1 mRNA which correlate with an inhibitory effect of miRNA-155 at $24 \mathrm{~h}$ and $36 \mathrm{~h}$. At a later time point, miRNA-155 reduces the signaling through the TLR-pathway by inhibition of re-expression of MyD88, the central signaling protein of TLR-4 and most other TLR's, and reduction of TAB2, a protein, which is an essential cofactor in the activation of TAK1. TAK1 is able to activate both the NF-KB and MAPK-pathway.

We proposed that TNF-a secretion is prolonged in hypothermia because of increased and prolonged expression of miRNA-155. We show here that miRNA-155 is indeed responsible for the prolonged TNF- $\alpha$ secretion. Overexpression of miRNA-155 at $39^{\circ} \mathrm{C}$ increased TNF- $\alpha$ to slightly higher levels than those of monocytes transfected with negative controls at $32^{\circ} \mathrm{C}$ making $" 39^{\circ} \mathrm{C}$ look like $32^{\circ} \mathrm{C}$. Of note, over-expression of miRNA-155 in hypothermia increased TNF- $\alpha$ further. The converse was also found to be true: suppression of miRNA155 at $32^{\circ} \mathrm{C}$ reduced TNF- $\alpha$ to slightly lower levels than in the negative control of $39^{\circ} \mathrm{C}$; thus, making " $32^{\circ} \mathrm{C}$ look like $39^{\circ} \mathrm{C}$ ". Interestingly, a further suppression of miRNA-155 at $39^{\circ} \mathrm{C}$ did not translate into significantly lower TNF- $\alpha$ levels, which 
suggests that miRNA-155 is expressed at a very low level and probably inactive. In summary, modulation of miRNA-155 expression is able to abolish the effects of temperature on cytokine secretion. We confirmed the pro-inflammatory action of miRNA-155 by analyzing IL-6 production. Similar to TNF-a, over-expression of miRNA-155 increased IL- 6 in both temperatures, whereas suppression of miRNA-155 reduced IL-6 expression in both temperatures. In addition, we show that these effects of miRNA-155 are likely to be mediated by SHIP-1, a well described target of miRNA-155. Over-expression of miRNA-155 suppresses SHIP-1 mRNA expression at both temperatures; reduction of miRNA-155 expression with miRNA-155 antagomirs increases the expression of SHIP-1 mRNA. These observations are in line with results of Kurowska-Stelarska et al. (145).

The effects of miRNA-155 on IL IL-10 are less clear. The effect of miRNA155 manipulation on IL-10 was not consistent. Suppression of miRNA-155 at $39^{\circ} \mathrm{C}$ reduced IL-10 significantly. In contrast, there was a slight trend for higher IL-10 levels in miRNA-155 antagomir transfected cells at $32^{\circ} \mathrm{C}$. Thus suggesting that temperature may influence the effect of microRNAs on an additional level independent of miRNA-155. This result contrasts with the report by KurowskaStelarska et al., who found that over-expression of miRNA-155 reduces IL-10 (145). The reasons for these differences remain unclear. Both experiments were conducted with primary human monocytes, which were freshly isolated by the same technique. In addition, the transfection reagent was also the same; the only difference was the source of the microRNA mimics, antagomirs and negative 
controls. Further research should be directed to answer this question. We hypothesize that temperature may influence other pathways which results in these inconsistent effect of miRNA-155 on IL-10. Alternatively, the production of other microRNAs, which were not investigated in our research or other mechanisms directing the production of $\mathrm{IL}-10$, may be strongly affected by temperature.

In summary, we demonstrate here that miRNA-155 is instrumental in the prolonged expression of TNF- $\alpha$ and that effect is likely to be mediated by suppression of SHIP-1. Furthermore, modulation of miRNA-155 expression is able to reverse the production of pro-inflammatory cytokines. These observations offer possibilities for therapeutic interventions. However, the effect of changes in miRNA-155 expression of IL-10 secretion and the influence of temperature on this process warrant further investigations. 


\section{CHAPTER VIII}

\section{IL-10 SUPPRESSES MIRNA-155 AND IS AN IMPORTANT NEGATIVE FEEDBACK LOOP}

We have shown in the previous experiment that miRNA-155 is responsible for the prolonged up-regulation of TNF- $\alpha$ under hypothermic conditions.

However, the regulation of miRNA-155 expression is not entirely elucidated. The transcription of miRNA-155 is initiated by NF-KB and the MAPK-pathway upon stimulation of the monocytes with LPS $(149,193,194,196)$. As Figure 15 indicates, there is no difference in miRNA-155 induction between $32^{\circ} \mathrm{C}$ and $39^{\circ} \mathrm{C}$ in the first $12 \mathrm{~h}$. After $12 \mathrm{~h}$ miRNA-155 expression declines at $39^{\circ} \mathrm{C}$ and remains at a lower level over the remaining study period. This difference in miRNA-155 could be explained by the prolonged activation of NF-KB, p38 and JNK in hypothermia. Since the expression is not different in the first $12 \mathrm{~h}$, it might as well be that other factors contribute or are mainly responsible for the observed difference in miRNA-155 expression after $12 \mathrm{~h}$. It has been shown that the expression of miRNA-155 is not only induced by ligands of the TLR-system but also by TNF- $\alpha$ (196). This is not surprising considering that the TLR-4 and the TNF-receptor share several of the intracellular signaling proteins such as IRAK$1 / 2$ and TRAF-6. Also, the TNF- $\alpha$ receptors utilizes the NF-KB and MAPK pathway. IL-10 has well described anti-inflammatory properties by suppressing 
the production of TNF- $\alpha$ and other pro-inflammatory cytokines directly (100). McCoy et al. demonstrated that IL-10 also suppresses miRNA-155 (198). We found in our experiment that the difference in IL-10 secretion is one of the most pronounced differences between $32^{\circ} \mathrm{C}$ and $39^{\circ} \mathrm{C}$, especially at the $12 \mathrm{~h}$ time point (Figures 11). Based on the literature and our own data, we hypothesized that IL10 may be the principle regulator of miRNA-155 expression as part of a negative feedback loop. In this feedback loop, IL-10 would not only reduce the production of pro-inflammatory cytokines directly, it would also reduce the signaling through the TLR-pathway by increasing the inhibitors SHIP-1 and SOCS-1 and reduce the expression of miRNA-155; thereby reinforcing the anti-inflammatory effect.

To delineate the role of IL-10 on miRNA-155 and subsequently TNF- $\alpha$ production we altered IL-10 action in the monocyte culture. For this purpose, we either added additional IL-10 or blocked the IL-10-Receptor. Adding additional IL10 to the $32^{\circ} \mathrm{C}$ culture would imitate conditions found at $39^{\circ} \mathrm{C}$. Blocking the IL-10receptor at $39^{\circ} \mathrm{C}$ abolishes the action of $\mathrm{IL}-10$ and would imitate conditions found at $32^{\circ} \mathrm{C}$. The demonstration of the biologic relevance of this feedback loop would indicate that microRNA's are not only regulators of protein production they are also controlled by proteins. A better understanding of such feedback loops may allow the targeted modulation of the cell response. 


\section{RESULTS}

\section{Addition of IL-10 to the Monocyte Culture at $32^{\circ} \mathrm{C}$}

Addition of IL-10 decreased the TNF- $\alpha$ production significantly at $12 \mathrm{~h}$ and $24 \mathrm{~h}$ to half the TNF- $\alpha$ concentration of the untreated $32^{\circ} \mathrm{C}$ samples (Figure 23). Additional IL-10 was also able to suppress the expression of miRNA-155 at $32^{\circ} \mathrm{C}$ at $12 \mathrm{~h}$ and $24 \mathrm{~h}$ although only the difference at $24 \mathrm{~h}$ was statistically significant (Figure 23). We chose to add IL-10 $4 \mathrm{~h}$ after the initial stimulus with LPS because IL-10 is not produced immediately. The $4 \mathrm{~h}$ time point was chosen based on preliminary findings that IL-10 starts rising around $4 \mathrm{~h}$.

\section{Blockade of IL-10-Receptor at $39^{\circ} \mathrm{C}$}

Blockade of the IL-10-Receptor with a specific antibody to the a subunit of the IL-10-Receptor increased the TNF- $\alpha$ protein levels at $39^{\circ} \mathrm{C}$ at $12 \mathrm{~h}$ and $24 \mathrm{~h}$ significantly (Figure 24). In line with these results, blockade of the IL-10-Receptor did increase miRNA-155 expression at $12 \mathrm{~h}$ and $24 \mathrm{~h}$ (Figure 24). As with the addition of IL-10 experiment, there was only a statistically significant effect on miRNA-155 expression at $24 \mathrm{~h}$. 
Figure 23: Effect of Additional IL-10 on TNF- $\alpha$ and miRNA-155 at $32^{\circ} \mathrm{C}$

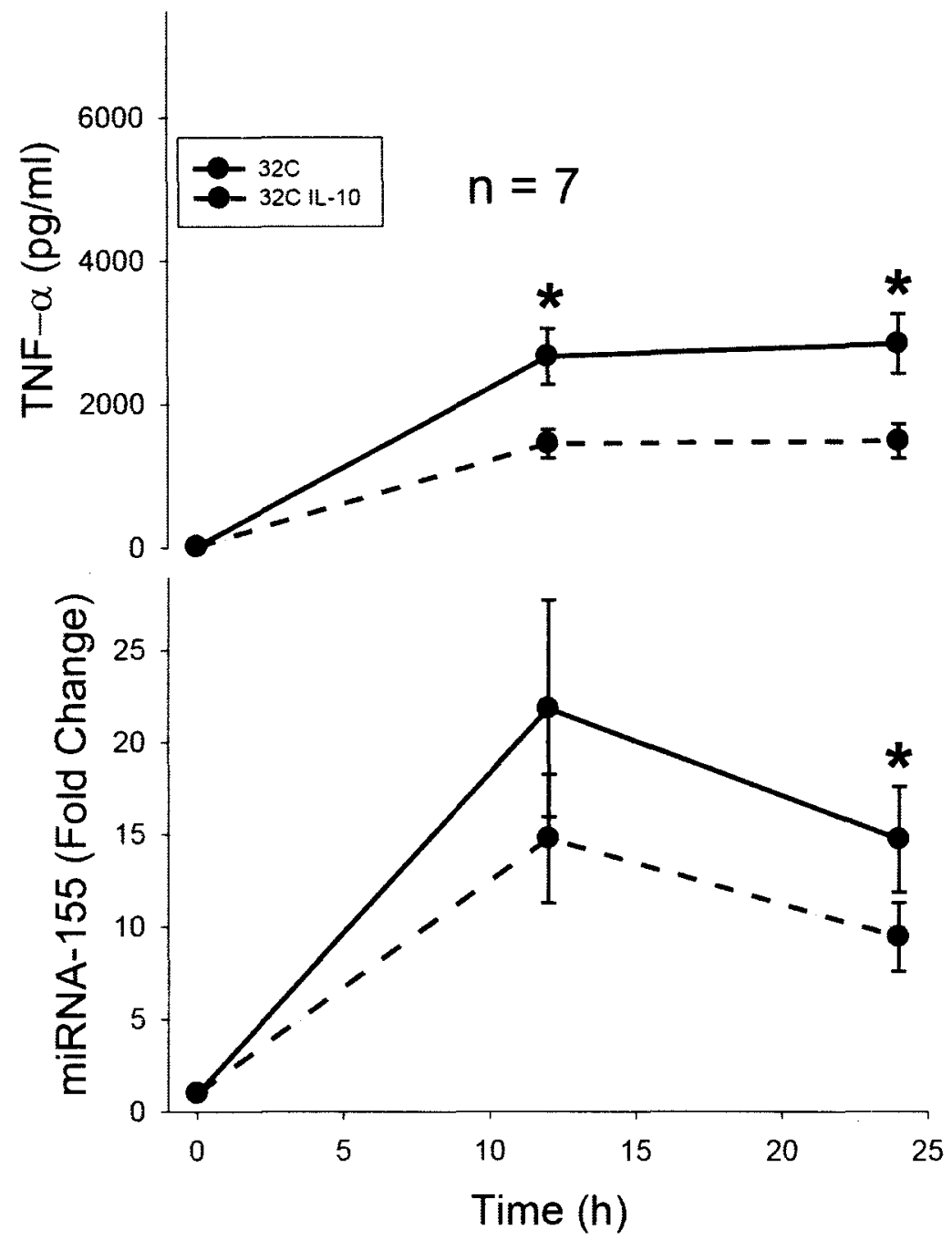

Addition of rhIL-10 effectively suppresses TNF- $\alpha$ protein secretion and miRNA-

155 production. In contrast to TNF-a, the suppressive effect of IL-10 occurs only after $24 \mathrm{~h}$ but probably lasts due to the prolonged action of miRNA-155 also longer. RhIL-10 was added $4 h$ after initial stimulation with LPS.

* indicates $p<0.05$; data are presented as mean \pm SEM 
Figure 24: Effect of IL-10 Receptor Blockade on TNF- $\alpha$ and miRNA-155 at $39^{\circ} \mathrm{C}$

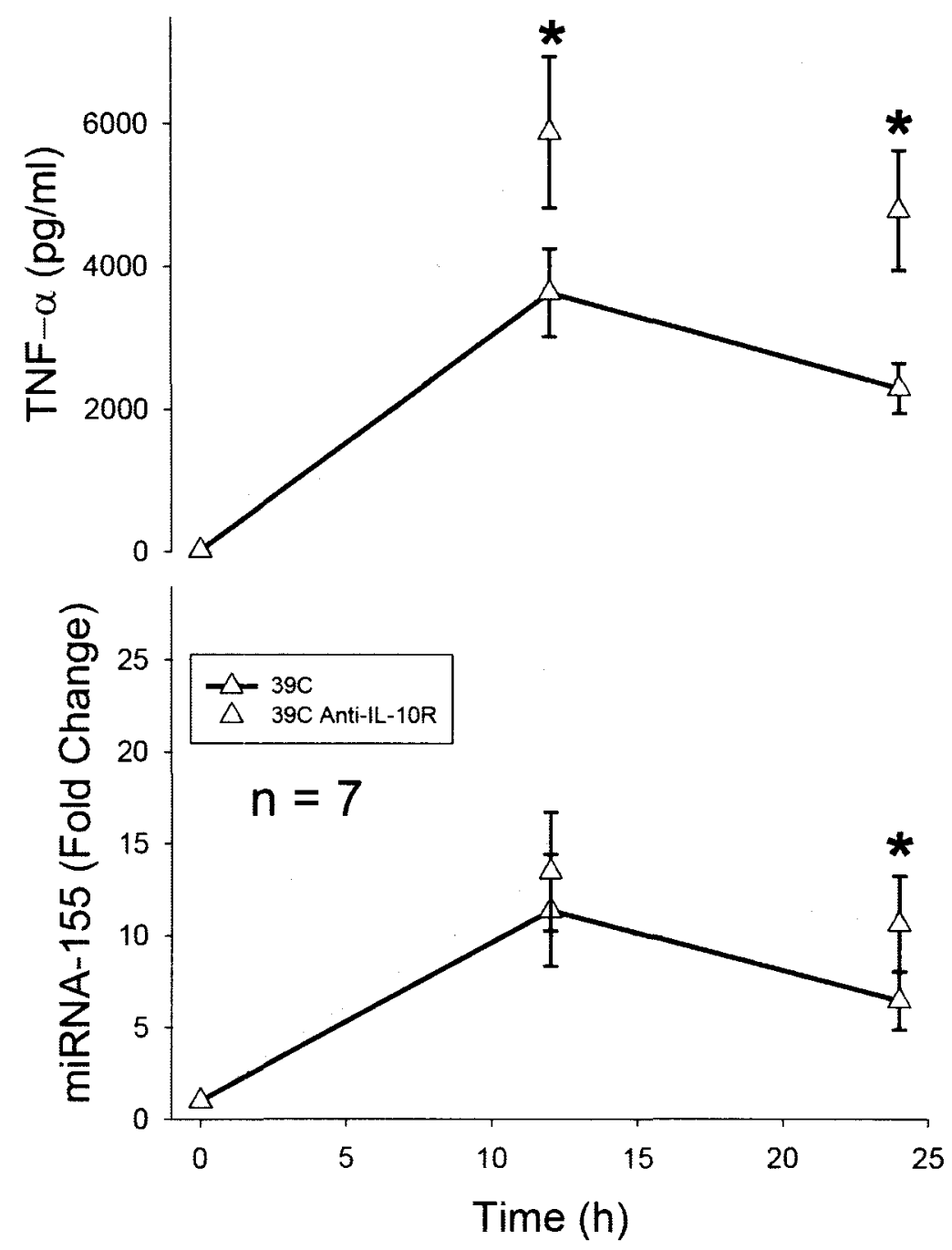

Blockade of the IL-10-Recpetor with anti-IL-10-Recpetor antibodies effectively blocked the action of IL-10 and increased TNF- $\alpha$ protein secretion and miRNA155 expression at $24 \mathrm{~h}$. Comparable to the addition of $\mathrm{IL}-10$ at $32^{\circ} \mathrm{C}$, the effect of the IL-10-Receptor blockade on miRNA-155 takes more time but will probably also last longer due to the action of miRNA-155.

* indicates $p<0.05$; data are presented as mean \pm SEM 


\section{DISCUSSION}

A tight regulation of the inflammatory response is pivotal for the host in order to mount an appropriate response to defend the host but also important in order to prevent excessive damage with potential fatal complications. The understanding of the various regulatory mechanisms would potentially allow for targeted interventions. IL-10 is a potent and well described negative regulator of the immune system $(97,98,100)$. It has been shown that administration of IL-10 in mice with endotoxemic shock and peritonitis abolishes the shock symptoms and increases survival $(97,98)$. One of the mechanisms by which IL-10 executes its anti-inflammatory properties is by blocking the transcription of pro-inflammatory cytokines such as TNF- $\alpha(100)$. The suppressive effect of IL-10 is not limited to cytokine genes; IL-10 also reduces the expression of miRNA-155 as we and Sheedy et al. have shown (198).

We showed here that IL-10, which is the most pronounced difference between $32^{\circ} \mathrm{C}$ and $39^{\circ} \mathrm{C}$, suppresses miRNA-155, resulting in an increased expression of SHIP-1 and SOCS-1 and therefore an inhibition of the TLR-4 signaling pathway, ultimately reducing TNF- $\alpha$ levels at $39^{\circ} \mathrm{C}$. We believe that we have demonstrated the causality of IL-10 by blocking the action of IL-10 at $39^{\circ} \mathrm{C}$, which resulted in an increase of miRNA-155 and TNF-a, thus, "making $39^{\circ} \mathrm{C}$ look like $32^{\circ} \mathrm{C}$. The opposite was also shown: administration of IL-10 after 4h of LPS stimulation at $32^{\circ} \mathrm{C}$ suppressed miRNA-155 and TNF- $\alpha$. IL-10 administration makes " $32^{\circ} \mathrm{C}$ look like $39^{\circ} \mathrm{C}$ ". We believe that we show here convincingly that IL-10 is part of an important negative feedback loop in 
regulation of the monocyte response. In this negative feedback loop, IL-10 suppresses miRNA-155 and the reduced expression of this microRNA results in an increased inhibition of the TLR-4 signaling pathway followed by a subsequent decrease of TNF- $\alpha$ at $39^{\circ} \mathrm{C}$. However, we do not believe that the reduced miRNA-155 expression is exclusively responsible for the decrease in TNF- $\alpha$. The direct suppression of IL-10 on the transcription of TNF- $\alpha$ is an important feature of the negative feedback loop. Our data indicate that reduced expression of miRNA-155 becomes effective at the $24 \mathrm{~h}$ time point but has long lasting effects. The addition of IL-10 as well as the block of the IL-10-Receptor had only effects on miRNA-155 at $24 \mathrm{~h}$, whereas TNF- $\alpha$ was suppressed already at $12 \mathrm{~h}$ time point (Figures 23 and 24). These findings suggest that the suppression of miRNA-155 is responsible for long lasting anti-inflammatory effects whereas direct suppression of TNF-a production is immediately effective.

Based on our results and the available literature, it seems that IL-10 acts on several levels of the immune response. It reduces the secretion and production of pro-inflammatory cytokines such as TNF-a but also immunemodulatory cytokines, which enhance phagocytosis and antigen-presenting capability of macrophages such as IFN-y and GM-CSF. The reduced expression of pro-inflammatory cytokines reduces the shock symptoms and the acute phase response. Furthermore, suppression of the antigen presentation reduces the activation of the adaptive immune system, which also produces pro-inflammatory cytokines. In addition, IL-10 modifies also microRNA-expression in monocytes. This action is important because microRNAs have long-lasting effects within the 
cells by modulation of pathways, which will alter the response of the cell when a subsequent pathogen is encountered. The mechanism, by which IL-10 impairs the antigen presentation process are not completely elucidated. However, it would not be surprising, if microRNAs are involved in this process and that these microRNAs are regulated by $\mathrm{IL}-10$.

In summary, the actions of IL-10 are not limited to one site of action; IL-10 effectively shuts down several pivotal points of the immune response: reduction of pro-inflammatory cytokines, reduced stimulation of cells of the adaptive immune system and modulation of intracellular signaling pathways by microRNAs. We propose here that the high levels of $\mathrm{IL}-10$ at $39^{\circ} \mathrm{C}$ contribute significantly to the reduced expression of miRNA-155 resulting in reduced TNF- $\alpha$ (Figure 25). 
Figure 25: Proposed Role of IL-10 in Suppression of miRNA-155 Expression and Subsequent Effect on TNF- $\alpha$

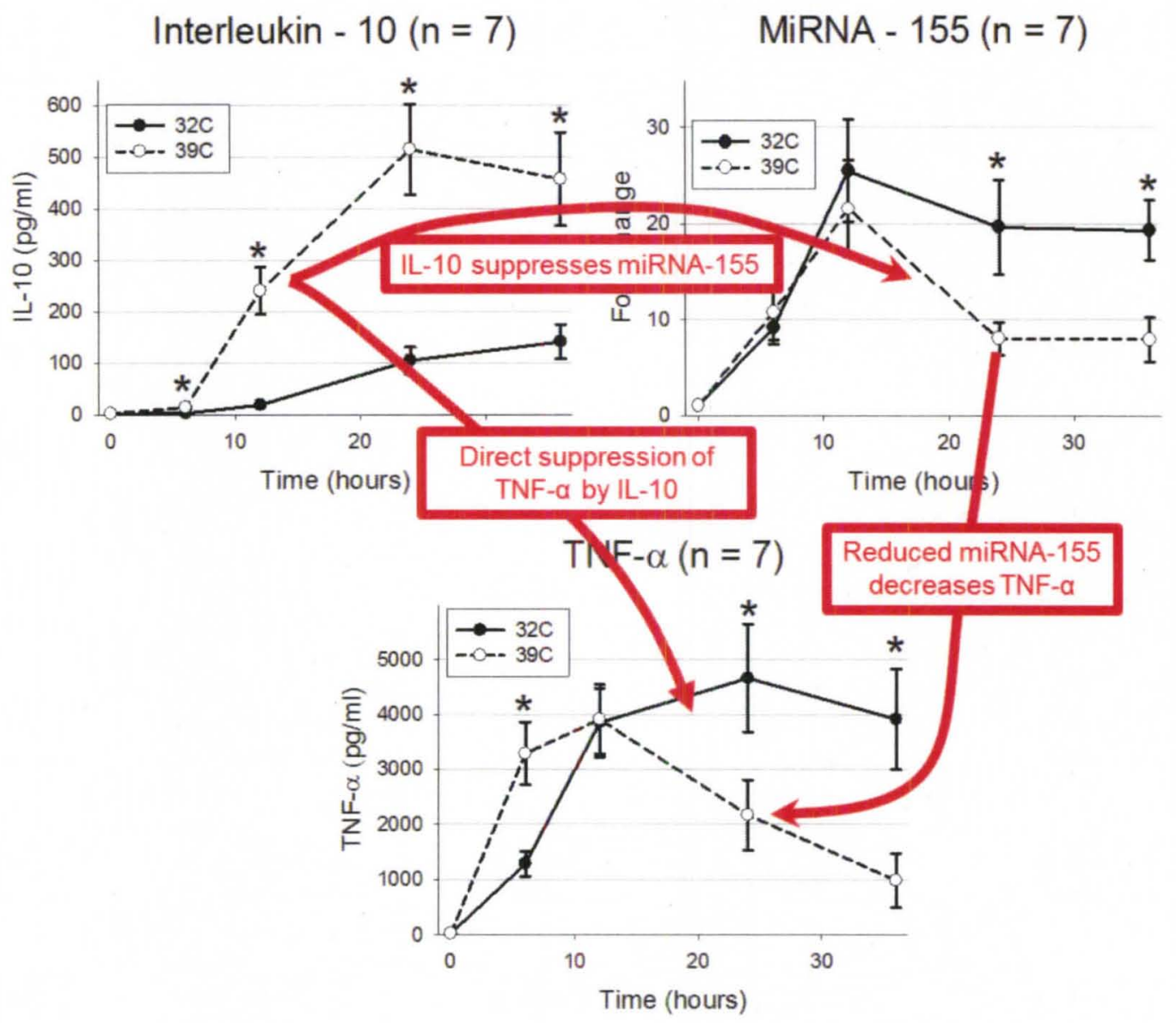

IL-10 suppresses TNF- $a$ directly at the $12 \mathrm{~h}$ time point. In addition, IL-10 suppresses miRNA-155, which increases the production and secretion of TNF- $\alpha$. The reduced expression of miRNA-155 would explain the reduced TNF- $\alpha$ production at $39^{\circ} \mathrm{C}$. The lack of $I L-10$ at $32^{\circ} \mathrm{C}$ results in sustained miRNA-155 expression and subsequently prolonged TNF-a levels. 


\section{CHAPTER IX}

\section{CONCLUSIONS AND OVERVIEW}

Hypothermia is a major risk factor for complications and mortality in elective and emergency surgery. Hypothermic patients are at an increased risk for wound infections and have a 3-fold higher mortality than non-hypothermic patients (2). Especially infection associated complications are more frequent in hypothermic patients but also cardio-vascular complications are increased $(7,31,167)$.

Previous work has shown that monocytes play an important role in host defense as the first line by recognizing invading pathogens and orchestrating the immune response $(54,62)$. It has also been demonstrated that there is prolonged secretion of pro-inflammatory cytokines and reduced IL-10 production in hypothermic monocytes $(18-21,23,161)$. The purpose of this project was to investigate the underlying cellular mechanisms, which may explain these changes in cytokines secretion. A summary of our results are outlined in Figure 26. We found that hypothermia prolongs the activation of pro-inflammatory signaling pathways including NF-KB, p38 and JNK. In contrast, Erk, a pathway which is pivotal for the production of $1 \mathrm{~L}-10$, has increased activation at $39^{\circ} \mathrm{C}$. These changes in pathway activation translate to an increased and prolonged up-regulation of TNF- $\alpha$ mRNA at $32^{\circ} \mathrm{C}$. At $39^{\circ} \mathrm{C}, 1 \mathrm{~L}-10 \mathrm{mRNA}$ 
production is highly induced and is translated into IL-10 protein. The IL-10 levels in the hypothermic monocyte culture are very low. MiRNA-155 is also upregulated in both temperatures, but miRNA-155 decreases at $39^{\circ} \mathrm{C}$ after $12 \mathrm{~h}$, whereas it remains up-regulated in hypothermia. MiRNA-155 inhibits the production of two negative regulators of the TLR-4 signaling pathway SHIP-1 and SOCS-1 $(139,145,149)$. The reduced expression of these two inhibitors prolongs the activation of the TLR-4 signaling and is responsible for the prolonged expression of TNF- $\alpha$ at $32^{\circ} \mathrm{C}$. The expression changes of SHIP-1 mRNA in both temperatures correlate well with this proposed role of miRNA-155. We demonstrate by modulation of miRNA-155 expression with mimics and antagomirs that miRNA-155 is directly responsible for the prolonged expression of TNF- $\alpha$ by changing the expression of SHIP-1. The reason for the reduced miRNA-155 expression at $39^{\circ} \mathrm{C}$ is the suppressive effect of IL-10. Blockade of the IL-10-Receptor in the $39^{\circ} \mathrm{C}$ monocyte culture increased both miRNA-155 and TNF- $\alpha$, thus supporting the notion that IL-10 provides a pivotal negative feedback loop in order to limit the production of pro-inflammatory cytokines. Therefore, the failure of $\mathrm{IL}-10$ production at $32^{\circ} \mathrm{C}$ results in a sequence of events, which prolongs the production of pro-inflammatory cytokines such as TNF- $\alpha$ and IL-6 and may ultimately be detrimental to the host.

Animal experiments showed that a prolonged expression of TNF- $\alpha$ leads to multiple organ failure and death $(91,199)$. We believe that the prolonged secretion of pro-inflammatory cytokines contributes to the detrimental effects of hypothermia in surgical patients. Administration of IL-10 abolishes the 
detrimental effects of high levels of pro-inflammatory cytokines as they can be found in endotoxemic shock or bacterial peritonitis $(97,98)$. It has been shown that IL-10 suppresses the release and production of TNF- $\alpha$ on the transcription level (100). We and others demonstrate additionally that IL-10 also suppresses miRNA-155 (198). Therefore, IL-10 not only suppresses TNF- $\alpha$ production directly, it also inactivates the pro-inflammatory signaling pathways by increasing the inhibitors of the TLR-4-pathway, which provides an additional and especially long-lasting inhibition of the pro-inflammatory response. Thus, $\mathbb{L}-10$ acts on several levels and in a sequential manner in order to limit the pro-inflammatory response.

These results are in line with a common hypothesis of the cause of multiple organ dysfunction. In his theory, a prolonged inflammatory response results in a prolonged suppressive counter-inflammatory response, which subsequently increases the susceptibility of the host organisms to sepsis $(186,187)$. In this case, our model mimics a systemically exaggerated inflammatory response. Dampening the increased immune response with administration of IL-10 would reduce the pro-inflammatory response and therefore also limit the counter-inflammatory response, which may result in an earlier restoration of immune function and subsequently reducing the risk for sepsis. Further investigation of this hypothesis should be undertaken by analysis of miRNA-155 expression or of other pro-inflammatory microRNAs such as miRNA-101 in blood or serum of patients with sepsis or after trauma. If upregulation of miRNA-155 or another pro-inflammatory microRNA correlates with 
poor outcome, it may be used to monitor immune function but also to guide immune modulatory treatments of these patients as discussed later.

Alternatively, our results could also mimic local conditions in a surgical incision or local infection. Hypothermia has been shown to reduce the ability of neutrophils and monocytes to produce ROS in hypothermia $(16,62,200)$. A prolonged secretion of pro-inflammatory cytokines may try to compensate for the failure of neutrophils to kill bacteria by attraction of more leukocytes and increased stimulation of the present phagocytes. Further investigation of this theory should focus on miRNA-155 expression in tissue macrophages such as Langerhans cells or wound healing macrophages. Associations between miRNA155 and other pro-inflammatory microRNA expression should be correlated with occurrence of wound infection. An association of miRNA-155 or other proinflammatory microRNA expression with surgical site infection could be used for risk stratification for infectious complications. In patients with a high risk for wound infection, additional measures such as prolonged local and systemic antibiotic treatment may be indicated.

Based on these experiments, miRNA-155 alone or possibly in combination with other pro-inflammatory microRNAs may be used to monitor the immune response and to guide immune-modulatory interventions. Patients with sepsis, after trauma or who are at a high risk for infectious complications may benefit from a functional evaluation of the immune system as indicated by high or low expression of pro-inflammatory microRNAs such as miRNA-155 followed by targeted interventions. Patients with high expression of miRNA-155 or other pro- 
inflammatory microRNAs may benefit from immune-suppressive treatments whereas immune-stimulatory medications such as IFN-y or GM-CSF support the recovery of patients with low miRNA-155 expression. Several clinical trials with immune-modulatory drugs have been undertaken and all of them failed. IFN- $\gamma$ was used in trauma patients with the goal to ameliorate post-traumatic immunesuppression. However, there was no difference in outcome between the placebo and IFN-Y group $(61,107)$. Trials with the goal to reduce the inflammatory response in sepsis such as the use of anti-TNF- $\alpha$ antibodies failed as well and even had detrimental outcomes (104-107). One of the reasons for the failure of immune-modulatory therapy in patients is that it is not possible to functionally asses the immune system thus far. Treatment of endotoxin shock in animals with either anti-TNF- $\alpha$ antibodies or IL-10 increases survival whereas immunestimulation in animals with a reduced immune response has been shown to increase survival $(94,95,97,98)$. However, it is not possible at the moment to assess the functional state of a patient's immune system and if this particular patient suffers from an exaggerated immune response, such as in an endotoxemic shock model, and likely would benefit from an anti-inflammatory or suffers from immune-suppression possibly benefiting from an immunestimulatory treatment. The first goal therefore should be to identify reliable markers for the functionality of a patient's immune system and then plan clinical trials based on the functional assessment of the immune system. MicroRNAs may provide this information because of their role as central regulators of cell function. Furthermore, patients receive several therapies such as mechanical 
ventilation, antibiotics, transfusions and many others, all of which may interfere with an additional immune-modulatory therapy. In addition, it is unlikely that one additional therapy among so many already used would have a massive impact on survival or other outcome parameters.

However, if it is possible to stratify the functional status of a patient's immune system, for example by using miRNA-155 or other pro-inflammatory microRNAs, targeted interventions, which alter the expression of miRNA-155 or any of these other microRNAs may be beneficial and improve outcome. Especially if the microRNA is causally involved in the disease process, such as miRNA-155, which interacts with the TLR-4 pathway, a therapy directed to alter the expression of this particular microRNA subsequently influencing the cell response may be successful. Systemic or local administration of miRNA-155 antagomirs may reduce TNF- $\alpha$ and limit the tissue damage and subsequent organ dysfunction in patients with an exaggerated immune-response.

Alternatively, administration of IL-10 in patients with high miRNA-155 expression in blood or serum may also be considered and would also inhibit TNF- $\alpha$ production directly, but in addition, also suppresses the expression of miRNA155 in circulating monocytes and local macrophages but also other leukocyte subsets. These two effects act synergistically and may be able to restore the monocyte function in patients. Immune-modulatory drugs such as IFN-y or GMCSF may influence miRNA-155 expression and subsequently be able to restore monocyte function and enhance immune function. Furthermore, the effect of rewarming to $37^{\circ} \mathrm{C}$ or even hyper-warming to $39^{\circ} \mathrm{C}$ on the reversibility of the 
TNF-a production should be investigated. Rewarming is the cornerstone of treatment of hypothermia in patients. If rewarming is not able to reverse the hypothermia induced changes in monocytes function, other strategies to restore monocyte function should be investigated.

There are several limitations for this work. Despite our attempts to use a gentle isolation process, the monocytes may be activated during this process and the monocyte response may be altered by this prior activation. The majority of the isolation process was conducted at $37^{\circ} \mathrm{C}$. However, some steps have to be performed at room temperature and expose therefore the monocytes to a hypothermic environment. Our data indicate that hypothermia profoundly alters the cell response, especially signaling pathways, resulting in strongly reduced IL10 production at $32^{\circ} \mathrm{C}$ resulting in prolonged TNF- $\alpha$ production. A potential contributor for these effects of hypothermia may also be a so far unidentified, temperature-sensitive protein or channel, which affects the monocyte response to LPS. Transient receptor potential cation channel subfamily $\vee$ member 1 (TRPV1) are sensitive to temperature changes and play an important role in temperature regulation of the body $(201,202)$. TRPV1 channels are also expressed on immune cells and the knock-out of TRPV1 results in a prolonged and increased pro-inflammatory response $(203,204)$. Closing of these channels by hypothermia may contribute to the increased secretion of pro-inflammatory cytokines in our model. Further research of the role of TRPV1 on the inflammatory response is warranted. 
In conclusion, we found that hypothermia increases and prolongs TNF- $\alpha$ and IL- 6 production by monocytes. The lack of IL-10 secretion under hypothermic conditions results in a reduced suppression of miRNA-155 expression resulting in a prolonged and increased TNF- $\alpha$ secretion. We therefore propose that hypothermia impairs an important feedback loop based on IL-10. The reduced activation of Erk at $32^{\circ} \mathrm{C}$ possibly contributes to the lack of $\mathrm{L}-10$. Further research should be focused on investigation of additional mechanisms, which are influenced by hypothermia such as TRPV1 membrane channels. In addition, the effect of rewarming, the standard therapy for hypothermic patients, on the reversibility of TNF-a secretion should be examined. 
Figure 26: Summary of Our Results

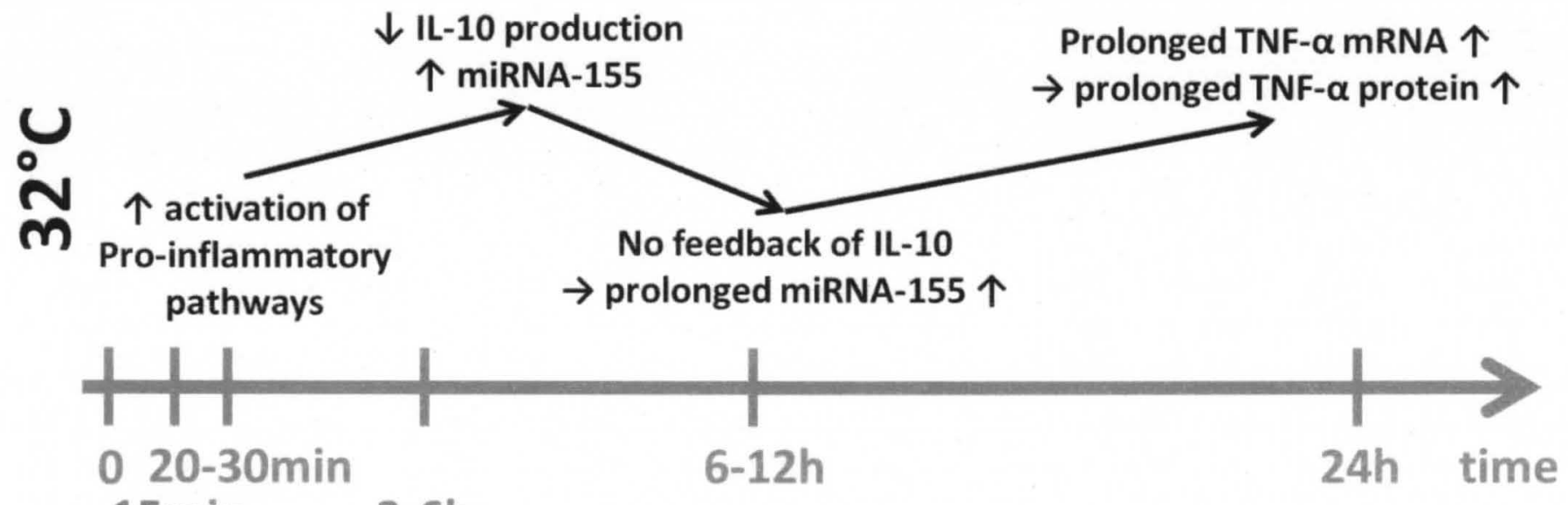

$\vec{\omega}$

20-30min

$\uparrow$ activation of

3-6h

○ $\rightarrow$ IL-10 induction

Feedback of IL-10

$\rightarrow$ suppresses miRNA-155 $\downarrow$

के

ก)

-- - -

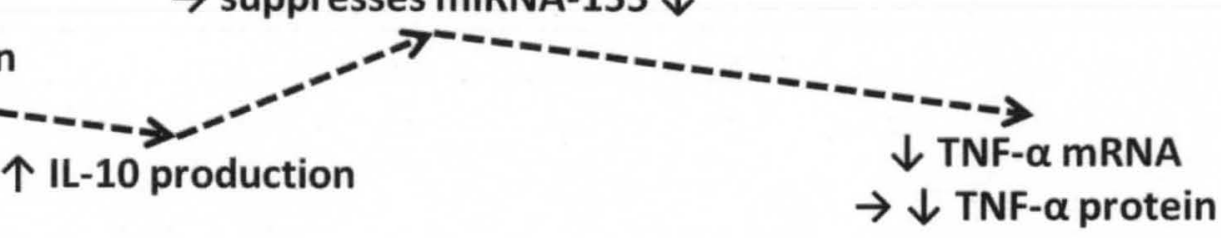




\section{REFERENCE LIST}

1. Martin RS, Kilgo PD, Miller PR, et al. Injury-associated hypothermia: an analysis of the 2004 National Trauma Data Bank. Shock 2005; 24:114-118

2. Mahid SS, Polk HC, Jr., Lewis JN, et al. Opportunities for improved performance in surgical specialty practice. Annals of Surgery 2008; 247:380-388

3. Thorsen K, Ringdal KG, Strand K, et al. Clinical and cellular effects of hypothermia, acidosis and coagulopathy in major injury. The British Journal of Surgery $2011 ; 98: 894-907$

4. Seamon MJ, Wobb J, Gaughan JP, et al. The effects of intraoperative hypothermia on surgical site infection: an analysis of 524 trauma laparotomies. Annals of Surgery 2012; 255:789-795

5. Inaba K, Teixeira PG, Rhee $P$, et al. Mortality impact of hypothermia after cavitary explorations in trauma. World J Surgery $2009 ; 33: 864-869$

6. Beilman GJ, Blondet $\mathrm{JJ}$, Nelson TR, et al. Early hypothermia in severely injured trauma patients is a significant risk factor for multiple organ dysfunction syndrome but not mortality. Annals of Surgery 2009; 249:845-850

7. Kurz A, Sessler DI, Lenhardt R. Perioperative normothermia to reduce the incidence of surgical-wound infection and shorten hospitalization. Study of Wound Infection and Temperature Group. The New England Journal of Medicine 1996; 334:1209-1215

8. Shafi S, Elliott AC, Gentilello L. Is hypothermia simply a marker of shock and injury severity or an independent risk factor for mortality in trauma patients? Analysis of a large national trauma registry. The Journal of Trauma 2005; 59:1081-1085

9. Ireland $S$, Endacott $R$, Cameron $P$, et al. The incidence and significance of accidental hypothermia in major trauma--a prospective observational study. Resuscitation 2011; 82:300-306 
10. Wang HE, Callaway CW, Peitzman AB, et al. Admission hypothermia and outcome after major trauma. Critical Care Medicine 2005; 33:1296-1301

11. Rajagopalan S, Mascha $\mathrm{E}, \mathrm{Na} J$, et al. The effects of mild perioperative hypothermia on blood loss and transfusion requirement. Anesthesiology 2008; 108:71-77

12. Horn EP, Bein B, Bohm R, et al. The effect of short time periods of preoperative warming in the prevention of peri-operative hypothermia. Anaesthesia 2012; 67:612-617

13. Advanced trauma life support for doctors ATLS : manuals for coordinators and faculty. Eight ed. Chicago, IL: American College of Surgeons, 2008;

14. Gentilello LM, Jurkovich GJ, Stark MS, et al. Is hypothermia in the victim of major trauma protective or harmful? A randomized, prospective study. Annals of Surgery $1997 ; 226: 439-447$; discussion 447-439

15. Wenisch C, Narzt E, Sessler DI, et al. Mild intraoperative hypothermia reduces production of reactive oxygen intermediates by polymorphonuclear leukocytes. Anesthesia and Analgesia 1996; 82:810-816

16. Akriotis $\mathrm{V}$, Biggar WD. The effects of hypothermia on neutrophil function in vitro. Journal of Leukocyte Biology 1985; 37:51-61

17. Hammarfjord O, Wallin RP. Dendritic cell function at low physiological temperature. Journal of Leukocyte Biology 2010; 88:747-756

18. Fairchild KD, Viscardi RM, Hester L, et al. Effects of hypothermia and hyperthermia on cytokine production by cultured human mononuclear phagocytes from adults and newborns. Journal of Interferon \& Cytokine Research 2000; 20:1049-1055

19. Fairchild KD, Singh IS, Patel S, et al. Hypothermia prolongs activation of NFkappaB and augments generation of inflammatory cytokines. Am J Physiol and Cell Physiol 2004; 287:C422-431

20. Russwurm S, Stonans I, Schwerter K, et al. Direct influence of mild hypothermia on cytokine expression and release in cultures of human peripheral blood mononuclear cells. Journal of Interferon \& Cytokine Research 2002; 22:215-221

21. Matsui $T$, Ishikawa $T$, Takeuchi $H$, et al. Mild hypothermia inhibits IL-10 production in peripheral blood mononuclear cells. Acta Anaesthesiol Scand 2004; 48:205-210 
22. Matsui T, Kakeda T. IL-10 production is reduced by hypothermia but augmented by hyperthermia in rat microglia. J Neurotrauma 2008; 25:709-715

23. Fairchild KD, Singh IS, Carter HC, et al. Hypothermia enhances phosphorylation of I\{kappa\}B kinase and prolongs nuclear localization of NF\{kappa\}B in lipopolysaccharide-activated macrophages. Am J Physiol Cell Physiol 2005; 289:C1114-1121

24. Sonna LA, Kuhlmeier MM, Carter HC, et al. Effect of moderate hypothermia on gene expression by THP-1 cells: a DNA microarray study. Physiol Genomics 2006; 26:91-98

25. Huang T, Solano J, He D, et al. Traumatic injury activates MAP kinases in astrocytes: mechanisms of hypothermia and hyperthermia. J Neurotrauma 2009; 26:1535-1545

26. Polk HC, Jr., Spratt JS, Jr., Bennett D, et al. Surgical Mortality and Survival from Colonic Carcinoma. Archives of Surgery 1964; 89:16-23

27. Billeter AT, Polk HC, Jr., Hohmann SF, et al. Mortality after elective colon resection: the search for outcomes that define quality in surgical practice. $J$ American College of Surgeons 2012; 214:436-443; discussion 443-434

28. Polk HC, Jr., Lopez-Mayor JF. Postoperative wound infection: a prospective study of determinant factors and prevention. Surgery 1969; 66:97-103

29. Turina M, Christ-Crain M, Polk HC, Jr. Diabetes and hyperglycemia: strict glycemic control. Critical Care Medicine 2006; 34:S291-300

30. Kluger MJ. Fever, its biology, evolution, and function. Princeton, N.J.: Princeton University Press, 1979;

31. Flores-Maldonado A, Medina-Escobedo CE, Rios-Rodriguez HM, et al. Mild perioperative hypothermia and the risk of wound infection. Arch Med Res 2001; $32: 227-231$

32. Guest JD, Vanni S, Silbert L. Mild hypothermia, blood loss and complications in elective spinal surgery. Spine Journal 2004; 4:130-137

33. Melling AC, Ali B, Scott EM, et al. Effects of preoperative warming on the incidence of wound infection after clean surgery: a randomised controlled trial. Lancet $2001 ; 358: 876-880$

34. Barone JE, Tucker JB, Cecere J, et al. Hypothermia does not result in more complications after colon surgery. The American Surgeon 1999; 65:356-359 
35. Lehtinen SJ, Onicescu G, Kuhn KM, et al. Normothermia to prevent surgical site infections after gastrointestinal surgery: holy grail or false idol? Annals of Surgery 2010; 252:696-704

36. Smith RL, Bohl JK, McElearney ST, et al. Wound infection after elective colorectal resection. Annals of Surgery 2004; 239:599-605; discussion 605-597

37. Walz JM, Paterson CA, Seligowski JM, et al. Surgical site infection following bowel surgery: a retrospective analysis of 1446 patients. Archives of Surgery 2006; 141:1014-1018; discussion 1018

38. Mommsen $\mathrm{P}$, Andruszkow $\mathrm{H}$, Fromke $\mathrm{C}$, et al. Effects of accidental . hypothermia on posttraumatic complications and outcome in multiple trauma patients. Injury 2011

39. Trentzsch H, Huber-Wagner S, Hildebrand F, et al. Hypothermia for prediction of death in severely injured blunt trauma patients. Shock 2012; 37:131139

40. Frank SM, Fleisher LA, Breslow MJ, et al. Perioperative maintenance of normothermia reduces the incidence of morbid cardiac events. A randomized clinical trial. JAMA : the Journal of the American Medical Association 1997; 277:1127-1134

41. Marik PE, Zaloga GP. Hypothermia and cytokines in septic shock. Norasept II Study Investigators. North American study of the safety and efficacy of murine monoclonal antibody to tumor necrosis factor for the treatment of septic shock. Intensive Care Medicine 2000; 26:716-721

42. Arons MM, Wheeler AP, Bernard GR, et al. Effects of ibuprofen on the physiology and survival of hypothermic sepsis. Ibuprofen in Sepsis Study Group. Critical Care Medicine 1999; 27:699-707

43. Laupland KB, Zahar JR, Adrie C, et al. Determinants of temperature abnormalities and influence on outcome of critical illness. Critical Care Medicine 2012; 40:145-151

44. Pittet $D$, Thievent $B$, Wenzel RP, et al. Bedside prediction of mortality from bacteremic sepsis. A dynamic analysis of ICU patients. Am J Respir Crit Care Med 1996; 153:684-693

45. Lee BH, Inui D, Suh GY, et al. Association of body temperature and antipyretic treatments with mortality of critically ill patients with and without sepsis: multi-centered prospective observational study. Crit Care 2012; 16:R33 
46. Leon LR, White AA, Kluger MJ. Role of IL-6 and TNF in thermoregulation and survival during sepsis in mice. Am J Physiol 1998; 275:R269-277

47. Murphy K. Janeway's Immunobiology 8th Edition: Garland Science, 2011;

48. Nautiyal KM, McKellar H, Silverman AJ, et al. Mast cells are necessary for the hypothermic response to LPS-induced sepsis. Am J Physiol Regul Integr Comp Physiol 2009; 296:R595-602

49. Auffray C, Sieweke MH, Geissmann F. Blood monocytes: development, heterogeneity, and relationship with dendritic cells. Annu Rev Immunol 2009; 27:669-692

50. Geissmann F, Manz MG, Jung S, et al. Development of monocytes, macrophages, and dendritic cells. Science 2010;327:656-661

51. Janeway CA, Jr., Medzhitov R. Innate immune recognition. Annu Rev Immunol 2002; 20:197-216

52. Livingston DH, Appel SH, Wellhausen SR, et al. Depressed interferon gamma production and monocyte HLA-DR expression after severe injury. Archives of Surgery 1988; 123:1309-1312

53. Appel SH, Wellhausen SR, Montgomery R, et al. Experimental and clinical significance of endotoxin-dependent HLA-DR expression on monocytes. The Journal of Surgical Research 1989; 47:39-44

54. Hershman MJ, Cheadle WG, Wellhausen SR, et al. Monocyte HLA-DR antigen expression characterizes clinical outcome in the trauma patient. The British Journal of Surgery 1990; 77:204-207

55. Cheadle WG, Hershman MJ, Wellihausen SR, et al. HLA-DR antigen expression on peripheral blood monocytes correlates with surgical infection. American Journal of Surgery 1991; 161:639-645

56. Docke WD, Randow F, Syrbe U, et al. Monocyte deactivation in septic patients: restoration by IFN-gamma treatment. Nat Med 1997; 3:678-681

57. Meisel C, Schefold JC, Pschowski R, et al. Granulocyte-macrophage colonystimulating factor to reverse sepsis-associated immunosuppression: a doubleblind, randomized, placebo-controlled multicenter trial. Am J Respir Crit Care Med 2009; 180:640-648 
58. Venet $F$, Tissot $S$, Debard AL, et al. Decreased monocyte human leukocyte antigen-DR expression after severe burn injury: Correlation with severity and secondary septic shock. Crit Care Med 2007; 35:1910-1917

59. Yang HM, Yu Y, Chai JK, et al. Low HLA-DR expression on CD14+ monocytes of burn victims with sepsis, and the effect of carbachol in vitro. Burns $2008 ; 34: 1158-1162$

60. Hershman MJ, Appel SH, Wellhausen SR, et al. Interferon-gamma treatment increases HLA-DR expression on monocytes in severely injured patients. Clinical and experimental immunology $1989 ; 77: 67-70$

61. Polk HC, Jr., Cheadle WG, Livingston $\mathrm{DH}$, et al. A randomized prospective clinical trial to determine the efficacy of interferon-gamma in severely injured patients. American Journal of Surgery 1992; 163:191-196

62. Qadan M, Gardner SA, Vitale DS, et al. Hypothermia and surgery: immunologic mechanisms for current practice. Annals of Surgery 2009; 250:134140

63. Dickinson A, Qadan M, Polk HC, Jr. Optimizing surgical care: a contemporary assessment of temperature, oxygen, and glucose. The American Surgeon 2010; 76:571-577

64. Belge KU, Dayyani F, Horelt A, et al. The proinflammatory CD14+CD16+DR++ monocytes are a major source of TNF. J Immunol 2002; 168:3536-3542

65. Ziegler-Heitbrock L, Ancuta P, Crowe S, et al. Nomenclature of monocytes and dendritic cells in blood. Blood 2010; 116:e74-80

66. Fingerle G, Pforte A, Passlick B, et al. The novel subset of CD14+/CD16+ blood monocytes is expanded in sepsis patients. Blood 1993; 82:3170-3176

67. Ziegler-Heitbrock L. The CD14+ CD16+ blood monocytes: their role in infection and inflammation. J Leukocyte Biology 2007; 81:584-592

68. Mizuno K, Toma T, Tsukiji H, et al. Selective expansion of CD16highCCR2subpopulation of circulating monocytes with preferential production of haem oxygenase (HO)-1 in response to acute inflammation. Clinical and experimental immunology $2005 ; 142: 461-470$

69. Kim OY, Monsel A, Bertrand M, et al. Differential down-regulation of HLA-DR on monocyte subpopulations during systemic inflammation. Crit Care 2010; 14:R61 
70. Shi C, Pamer EG. Monocyte recruitment during infection and inflammation. Nat Rev Immunol 2011; 11:762-774

71. Gordon S, Taylor PR. Monocyte and macrophage heterogeneity. Nat Rev Immunol 2005; 5:953-964

72. Medzhitov R. Recognition of microorganisms and activation of the immune response. Nature 2007; 449:819-826

73. Lotze MT, Tracey KJ. High-mobility group box 1 protein (HMGB1): nuclear weapon in the immune arsenal. Nat Rev Immunol 2005; 5:331-342

74. Levy RM, Mollen KP, Prince JM, et al. Systemic inflammation and remote organ injury following trauma require HMGB1. Am J Physiol Regul Integr Comp Physiol 2007; 293:R1538-1544

75. Rittirsch D, Flierl MA, Ward PA. Harmful molecular mechanisms in sepsis. Nat Rev Immunol 2008; 8:776-787

76. Hreggvidsdottir HS, Ostberg $\mathrm{T}$, Wahamaa $\mathrm{H}$, et al. The alarmin HMGB1 acts in synergy with endogenous and exogenous danger signals to promote inflammation. J Leukocyte Biology 2009; 86:655-662

77. Bianchi ME. DAMPs, PAMPs and alarmins: all we need to know about danger. J Leukocyte Biology 2007; 81:1-5

78. Lotze MT, Zeh HJ, Rubartelli A, et al. The grateful dead: damage-associated molecular pattern molecules and reduction/oxidation regulate immunity. Immunological reviews 2007; 220:60-81

79. Netea MG, van der Graaf C, Van der Meer JW, et al. Toll-like receptors and the host defense against microbial pathogens: bringing specificity to the innateimmune system. J Leukocyte Biology 2004; 75:749-755

80. Akira S, Uematsu S, Takeuchi O. Pathogen recognition and innate immunity. Cell 2006; 124:783-801

81. Kasuga K, Yang R, Porter TF, et al. Rapid Appearance of Resolvin Precursors in Inflammatory Exudates: Novel Mechanisms in Resolution. Journal of Immunology 2008; 181:8677-8687

82. Serhan CN, Chiang N, Van Dyke TE. Resolving inflammation: dual antiinflammatory and pro-resolution lipid mediators. Nature Reviews Immunology $2008 ; 8: 349-361$ 
83. Hasselgren PO, Pedersen $\mathrm{P}$, Sax HC, et al. Current concepts of protein turnover and amino acid transport in liver and skeletal muscle during sepsis. Archives of Surgery 1988; 123:992-999

84. Moshage H. Cytokines and the hepatic acute phase response. J Pathol 1997; 181:257-266

85. Biolo G, Toigo G, Ciocchi B, et al. Metabolic response to injury and sepsis: changes in protein metabolism. Nutrition 1997; 13:52S-57S

86. Turina $\mathrm{M}$, Fry DE, Polk HC, Jr. Acute hyperglycemia and the innate immune system: clinical, cellular, and molecular aspects. Critical Care Medicine 2005; 33:1624-1633

87. de Jong HK, van der Poll T, Wiersinga WJ. The systemic pro-inflammatory response in sepsis. J Innate Immun 2010; 2:422-430

88. Amara U, Flierl MA, Rittirsch D, et al. Molecular intercommunication between the complement and coagulation systems. Journal of immunology 2010; 185:5628-5636

89. Heinrich PC, Castell JV, Andus T. Interleukin- 6 and the acute phase response. Biochem J 1990; 265:621-636

90. Baumann H, Gauldie J. The acute phase response. Immunol Today 1994; $15: 74-80$

91. Tracey KJ, Fong Y, Hesse DG, et al. Anti-cachectin/TNF monoclonal antibodies prevent septic shock during lethal bacteraemia. Nature 1987; 330:662-664

92. Malangoni MA, Livingston $\mathrm{DH}$, Sonnenfeld $\mathrm{G}$, et al. Interferon gamma and tumor necrosis factor alpha. Use in gram-negative infection after shock. Archives of Surgery 1990; $125: 444-446$

93. Dinarello CA, Gelfand JA, Wolff SM. Anticytokine strategies in the treatment of the systemic inflammatory response syndrome. JAMA : the Journal of the American Medical Association 1993; 269:1829-1835

94. Alexander HR, Sheppard BC, Jensen JC, et al. Treatment with recombinant human tumor necrosis factor-alpha protects rats against the lethality, hypotension, and hypothermia of gram-negative sepsis. The Journal of Clinical Investigation 1991; 88:34-39 
95. Gaar E, Naziri W, Cheadle WG, et al. Improved survival in simulated surgical infection with combined cytokine, antibiotic and immunostimulant therapy. The British Journal of Surgery 1994; 81:1309-1311

96. Pelekanou A, Tsangaris I, Kotsaki A, et al. Decrease of CD4-lymphocytes and apoptosis of CD14-monocytes are characteristic alterations in sepsis caused by ventilator-associated pneumonia: results from an observational study. Crit Care 2009; 13:R172

97. Gerard C, Bruyns C, Marchant A, et al. Interleukin 10 reduces the release of tumor necrosis factor and prevents lethality in experimental endotoxemia. J Exp Med 1993; $177: 547-550$

98. van der Poll T, Marchant A, Buurman WA, et al. Endogenous IL-10 protects mice from death during septic peritonitis. J Immunol 1995; 155:5397-5401

99. Saraiva M, O'Garra A. The regulation of IL-10 production by immune cells. Nat Rev Immunol 2010; 10:170-181

100. Smallie T, Ricchetti G, Horwood NJ, et al. IL-10 inhibits transcription elongation of the human TNF gene in primary macrophages. J Exp Med 2010; 207:2081-2088

101. Huber TS, Gaines GC, Welborn MB, 3rd, et al. Anticytokine therapies for acute inflammation and the systemic inflammatory response syndrome: IL-10 and ischemia/reperfusion injury as a new paradigm. Shock 2000; 13:425-434

102. Wesche DE, Lomas-Neira JL, Perl M, et al. Leukocyte apoptosis and its significance in sepsis and shock. J Leukocyte Biology 2005; 78:325-337

103. Parrino J, Hotchkiss RS, Bray M. Prevention of immune cell apoptosis as potential therapeutic strategy for severe infections. Emerg Infect Dis 2007; 13:191-198

104. Abraham E, Wunderink R, Silverman $\mathrm{H}$, et al. Efficacy and safety of monoclonal antibody to human tumor necrosis factor alpha in patients with sepsis syndrome. A randomized, controlled, double-blind, multicenter clinical trial. TNFalpha MAb Sepsis Study Group. JAMA : the Journal of the American Medical Association 1995; 273:934-941

105. Abraham E, Glauser MP, Butler T, et al. p55 Tumor necrosis factor receptor fusion protein in the treatment of patients with severe sepsis and septic shock. A randomized controlled multicenter trial. Ro 45-2081 Study Group. JAMA : the Journal of the American Medical Association 1997; 277:1531-1538 
106. Abraham LJ, Kroeger KM. Impact of the -308 TNF promoter polymorphism on the transcriptional regulation of the TNF gene: relevance to disease. Journal of Leukocyte Biology 1999; 66:562-566

107. Spruijt NE, Visser T, Leenen LP. A systematic review of randomized controlled trials exploring the effect of immunomodulative interventions on infection, organ failure, and mortality in trauma patients. Crit Care 2010; 14:R150

108. Muzio M, Polentarutti N, Bosisio D, et al. Toll-like receptor family and signalling pathway. Biochem Soc Trans 2000; 28:563-566

109. Guha M, Mackman N. LPS induction of gene expression in human monocytes. Cell Signal 2001; 13:85-94

110. Hu X, Chakravarty SD, Ivashkiv LB. Regulation of interferon and Toll-like receptor signaling during macrophage activation by opposing feedforward and feedback inhibition mechanisms. Immunological reviews 2008; 226:41-56

111. Demetz E, Tancevski I, Duwensee K, et al. Inhibition of hepatic scavenger receptor-class $B$ type I by RNA interference decreases atherosclerosis in rabbits. Atherosclerosis 2012; 222:360-366

112. Baccala R, Gonzalez-Quintial R, Lawson BR, et al. Sensors of the innate immune system: their mode of action. Nat Rev Rheumatol 2009; 5:448-456

113. Rosenstiel P, Schreiber S. NOD-like receptors--pivotal guardians of the immunological integrity of barrier organs. Adv Exp Med Biol 2009; 653:35-47

114. Bonardi V, Cherkis K, Nishimura MT, et al. A new eye on NLR proteins: focused on clarity or diffused by complexity? Curr Opin Immunol 2012; 24:41-50

115. Blander JM, Sander LE. Beyond pattern recognition: five immune checkpoints for scaling the microbial threat. Nat Rev Immunol 2012; 12:215-225

116. Wright SD, Ramos RA, Tobias PS, et al. CD14, a receptor for complexes of lipopolysaccharide (LPS) and LPS binding protein. Science 1990; 249:1431-1433

117. O'Neill LA. Signal transduction pathways activated by the IL-1 receptor/tolllike receptor superfamily. Curr Top Microbiol Immunol 2002; 270:47-61

118. Leung WH, Tarasenko T, Bolland S. Differential roles for the inositol phosphatase SHIP in the regulation of macrophages and lymphocytes. Immunol Res 2009; 43:243-251 
119. Yasukawa H, Sasaki A, Yoshimura A. Negative regulation of cytokine signaling pathways. Annu Rev Immunol 2000; 18:143-164

120. Nicola NA, Greenhalgh CJ. The suppressors of cytokine signaling (SOCS) proteins: important feedback inhibitors of cytokine action. Exp Hematol 2000; 28:1105-1112

121. Rao KM. MAP kinase activation in macrophages. J Leukocyte Biology 2001; 69:3-10

122. Zhang $\mathrm{YL}$, Dong C. MAP kinases in immune responses. Cell Mol Immunol $2005 ; 2: 20-27$

123. Karin M, Ben-Neriah Y. Phosphorylation meets ubiquitination: the control of NF-[kappa]B activity. Annu Rev Immunol 2000; 18:621-663

124. Perkins ND. Integrating cell-signalling pathways with NF-kappaB and IKK function. Nat Rev Mol Cell Biol 2007; 8:49-62

125. Hayden MS, Ghosh S. NF-kappaB, the first quarter-century: remarkable progress and outstanding questions. Genes Dev 2012; 26:203-234

126. Guha M, O'Connell MA, Pawlinski R, et al. Lipopolysaccharide activation of the MEK-ERK1/2 pathway in human monocytic cells mediates tissue factor and tumor necrosis factor alpha expression by inducing Elk-1 phosphorylation and Egr-1 expression. Blood 2001; 98:1429-1439

127. Jeffrey KL, Brummer T, Rolph MS, et al. Positive regulation of immune cell function and inflammatory responses by phosphatase PAC-1. Nat Immunol 2006; 7:274-283

128. Abraham SM, Clark AR. Dual-specificity phosphatase 1: a critical regulator of innate immune responses. Biochem Soc Trans 2006; 34:1018-1023

129. Patterson KI, Brummer T, O'Brien PM, et al. Dual-specificity phosphatases: critical regulators with diverse cellular targets. Biochem J 2009; 418:475-489

130. Chi H, Barry SP, Roth RJ, et al. Dynamic regulation of pro- and antiinflammatory cytokines by MAPK phosphatase 1 (MKP-1) in innate immune responses. Proc Natl Acad Sci U S A 2006; 103:2274-2279

131. Lagos-Quintana $M$, Rauhut $R$, Lendeckel $W$, et al. Identification of novel genes coding for small expressed RNAs. Science 2001; 294:853-858 
132. Dugas DV, Bartel B. MicroRNA regulation of gene expression in plants. Curr Opin Plant Biol 2004; 7:512-520

133. Bartel DP. MicroRNAs: genomics, biogenesis, mechanism, and function. Cell 2004; 116:281-297

134. Billeter AT, Druen D, Kanaan ZM, et al. MicroRNAs: new helpers for surgeons? Surgery 2012; 151:1-5

135. Vasudevan S, Tong $Y$, Steitz JA. Switching from repression to activation: microRNAs can up-regulate translation. Science 2007; 318:1931-1934

136. Taganov KD, Boldin MP, Chang KJ, et al. NF-kappaB-dependent induction of microRNA miR-146, an inhibitor targeted to signaling proteins of innate immune responses. Proc Natl Acad Sci U S A 2006; 103:12481-12486

137. Nahid MA, Pauley KM, Satoh M, et al. miR-146a is critical for endotoxininduced tolerance: Implication in Innate Immunity. J Biol Chem 2009; 284:3459034599

138. Tili E, Croce CM, Michaille JJ. miR-155: on the crosstalk between inflammation and cancer. Int Rev Immunol 2009; 28:264-284

139. Cremer TJ, Ravneberg DH, Clay CD, et al. MiR-155 induction by F. novicida but not the virulent $F$. tularensis results in SHIP down-regulation and enhanced pro-inflammatory cytokine response. PLoS One 2009; 4:e8508

140. Ceppi M, Pereira PM, Dunand-Sauthier I, et al. MicroRNA-155 modulates the interleukin-1 signaling pathway in activated human monocyte-derived dendritic cells. Proc Natl Acad Sci U S A 2009; 106:2735-2740

141. Nahid MA, Satoh M, Chan EK. Mechanistic Role of MicroRNA-146a in Endotoxin-Induced Differential Cross-Regulation of TLR Signaling. J Immunol 2010

142. Cui JG, Li YY, Zhao Y, et al. Differential regulation of interleukin-1 receptorassociated kinase-1 (IRAK-1) and IRAK-2 by microRNA-146a and NF-kappaB in stressed human astroglial cells and in Alzheimer disease. J Biol Chem 2010; 285:38951-38960

143. Sheedy FJ, Palsson-McDermott E, Hennessy EJ, et al. Negative regulation of TLR4 via targeting of the proinflammatory tumor suppressor PDCD4 by the microRNA miR-21. Nature immunology 2010; 11:141-147 
144. O'Neill LA, Sheedy FJ, McCoy CE. MicroRNAs: the fine-tuners of Toll-like receptor signalling. Nat Rev Immunol 2011; 11:163-175

145. Kurowska-Stolarska M, Alivernini S, Ballantine LE, et al. MicroRNA-155 as a proinflammatory regulator in clinical and experimental arthritis. Proc Natl Acad Sci U S A 2011; 108:11193-11198

146. Zhu QY, Liu Q, Chen JX, et al. MicroRNA-101 targets MAPK phosphatase-1 to regulate the activation of MAPKs in macrophages. J Immunol 2010; 185:74357442

147. Tili E, Michaille JJ, Cimino A, et al. Modulation of miR-155 and miR-125b levels following lipopolysaccharide/TNF-alpha stimulation and their possible roles in regulating the response to endotoxin shock. J Immunol 2007; 179:5082-5089

148. Tang B, Xiao B, Liu Z, et al. Identification of MyD88 as a novel target of miR-155, involved in negative regulation of Helicobacter pylori-induced inflammation. FEBS Lett 2010; 584:1481-1486

149. Wang $P$, Hou J, Lin L, et al. Inducible microRNA-155 feedback promotes type I IFN signaling in antiviral innate immunity by targeting suppressor of cytokine signaling 1. J Immunol 2010; 185:6226-6233

150. Hou J, Wang P, Lin L, et al. MicroRNA-146a feedback inhibits RIG-Idependent Type I IFN production in macrophages by targeting TRAF6, IRAK1, and IRAK2. J Immunol 2009; 183:2150-2158

151. Liu Z, Xiao B, Tang B, et al. Up-regulated microRNA-146a negatively modulate Helicobacter pylori-induced inflammatory response in human gastric epithelial cells. Microbes Infect 2010; 12:854-863

152. Meng F, Henson $R$, Wehbe-Janek $H$, et al. MicroRNA-21 regulates expression of the PTEN tumor suppressor gene in human hepatocellular cancer. Gastroenterology 2007; 133:647-658

153. Bhatti I, Lee A, James V, et al. Knockdown of microRNA-21 Inhibits Proliferation and Increases Cell Death by Targeting Programmed Cell Death 4 (PDCD4) in Pancreatic Ductal Adenocarcinoma. J Gastrointest Surg 2010

154. Kulda V, Pesta M, Topolcan O, et al. Relevance of miR-21 and miR-143 expression in tissue samples of colorectal carcinoma and its liver metastases. Cancer Genet Cytogenet 2010; 200:154-160 
155. Nielsen BS, Jorgensen S, Fog JU, et al. High levels of microRNA-21 in the stroma of colorectal cancers predict short disease-free survival in stage II colon cancer patients. Clin Exp Metastasis 2011; 28:27-38

156. Wei J, Gao W, Zhu CJ, et al. Identification of plasma microRNA-21 as a biomarker for early detection and chemosensitivity of non-small cell lung cancer. Chin J Cancer 2011; 30:407-414

157. Wang ZX, Bian HB, Wang JR, et al. Prognostic significance of serum miRNA-21 expression in human non-small cell lung cancer. Journal of Surgical Oncology 2011; 104:847-851

158. Gao W, Lu X, Liu L, et al. MiRNA-21: A biomarker predictive for platinumbased adjuvant chemotherapy response in patients with non-small cell lung cancer. Cancer biology \& therapy 2012; 13:330-340

159. Liu XG, Zhu WY, Huang YY, et al. High expression of serum miR-21 and tumor miR-200c associated with poor prognosis in patients with lung cancer. Medical Oncology 2012; 29:618-626

160. Fairchild KD, Singh IS, Patel S, et al. Hypothermia prolongs activation of NF-kappaB and augments generation of inflammatory cytokines. American journal of physiology. Cell Physiology 2004; 287:C422-431

161. Matsui $T$, Ishikawa $T$, Takeuchi $H$, et al. Mild hypothermia promotes proinflammatory cytokine production in monocytes. Journal of Neurosurgical Anesthesiology 2006; 18:189-193

162. Kimura A, Sakurada S, Ohkuni H, et al. Moderate hypothermia delays proinflammatory cytokine production of human peripheral blood mononuclear cells. Crit Care Med 2002; 30:1499-1502

163. Lundeland B, Osterholt $\mathrm{H}$, Gundersen $\mathrm{Y}$, et al. Moderate temperature alterations affect Gram-negative immune signalling in ex vivo whole blood. Scandinavian Journal of Clinical and Laboratory Investigation 2012; 72:246-252

164. Arai T, Kaneko H, Ohnishi H, et al. Hypothermia augments NF-kappaB activity and the production of IL-12 and IFN-gamma. Allergol Int 2008; 57:331338

165. Dickinson A, Qadan M, Weller C, et al. In vitro study of variables relevant to perioperative care of the surgical patient: glucose, osmolarity, and rewarming. Journal of the American College of Surgeons 2011; 212:180-186 
166. Fries M, Stoppe C, Brucken D, et al. Influence of mild therapeutic hypothermia on the inflammatory response after successful resuscitation from cardiac arrest. J Crit Care 2009; 24:453-457

167. Perbet S, Mongardon N, Dumas F, et al. Early-onset pneumonia after cardiac arrest: characteristics, risk factors and influence on prognosis. Am J Respir Crit Care Med 2011; 184:1048-1054

168. Aibiki M, Maekawa S, Ogura S, et al. Effect of moderate hypothermia on systemic and internal jugular plasma IL-6 levels after traumatic brain injury in humans. J Neurotrauma 1999; 16:225-232

169. Remick DG, Xioa H. Hypothermia and sepsis. Frontiers in bioscience : a journal and virtual library 2006; 11:1006-1013

170. Torossian A, Ruehlmann S, Middeke M, et al. Mild preseptic hypothermia is detrimental in rats. Critical Care Medicine 2004; 32:1899-1903

171. Torossian A, RuehImann S, Middeke M, et al. Deleterious effects of mild hypothermia in septic rats are ameliorated by granulocyte colony-stimulating factor. Anesthesiology 2003; 99:1087-1092

172. Huet $O$, Kinirons $B$, Dupic $L$, et al. Induced mild hypothermia reduces mortality during acute inflammation in rats. Acta Anaesthesiol Scand 2007; $51: 1211-1216$

173. Taniguchi $T$, Kanakura $H$, Takemoto $Y$, et al. Effects of hypothermia on mortality and inflammatory responses to endotoxin-induced shock in rats. Clinical and diagnostic laboratory immunology 2003; 10:940-943

174. Xiao H, Remick DG. Correction of perioperative hypothermia decreases experimental sepsis mortality by modulating the inflammatory response. Critical Care Medicine 2005; 33:161-167

175. Karp CL. Unstressing intemperate models: how cold stress undermines mouse modeling. J Exp Med 2012; 209:1069-1074

176. Sonna LA, Kuhlmeier MM, Khatri $P$, et al. A microarray analysis of the effects of moderate hypothermia and rewarming on gene expression by human hepatocytes (HepG2). Cell Stress Chaperones 2010; 15:687-702

177. Yang D, Guo S, Zhang T, et al. Hypothermia attenuates ischemia/reperfusion-induced endothelial cell apoptosis via alterations in apoptotic pathways and JNK signaling. FEBS Lett 2009; 583:2500-2506 
178. Diestel A, Roessler J, Berger F, et al. Hypothermia downregulates inflammation but enhances IL-6 secretion by stimulated endothelial cells. Cryobiology 2008; 57:216-222

179. Kluger MJ, Rudolph K, Soszynski D, et al. Effect of heat stress on LPSinduced fever and tumor necrosis factor. Am J Physiol 1997; 273:R858-863

180. Chu EK, Ribeiro SP, Slutsky AS. Heat stress increases survival rates in lipopolysaccharide-stimulated rats. Crit Care Med 1997; 25:1727-1732

181. Gabai VL, Sherman MY. Invited review: Interplay between molecular chaperones and signaling pathways in survival of heat shock. J Appl Physiol 2002; 92:1743-1748

182. Livak KJ, Schmittgen TD. Analysis of relative gene expression data using real-time quantitative PCR and the 2(-Delta Delta $C(T)$ ) Method. Methods 2001; $25: 402-408$

183. Fire A, Xu S, Montgomery MK, et al. Potent and specific genetic interference by double-stranded RNA in Caenorhabditis elegans. Nature 1998; 391:806-811

184. Huang $B$, Zhao J, Lei $Z$, et al. miR-142-3p restricts cAMP production in CD4+CD25- $T$ cells and CD4+CD25+ TREG cells by targeting AC9 mRNA. EMBO reports 2009; 10:180-185

185. Lu LF, Boldin MP, Chaudhry A, et al. Function of miR-146a in controlling Treg cell-mediated regulation of Th1 responses. Cell 2010; 142:914-929

186. Keel M, Trentz O. Pathophysiology of polytrauma. Injury 2005; 36:691-709

187. Osuchowski MF, Welch K, Siddiqui J, et al. Circulating cytokine/inhibitor profiles reshape the understanding of the SIRS/CARS continuum in sepsis and predict mortality. J Immunol 2006; 177:1967-1974

188. Ajuebor MN, Das AM, Virag L, et al. Role of resident peritoneal macrophages and mast cells in chemokine production and neutrophil migration in acute inflammation: evidence for an inhibitory loop involving endogenous IL-10. J Immunol 1999; 162:1685-1691

189. Dorion S, Landry J. Activation of the mitogen-activated protein kinase pathways by heat shock. Cell Stress Chaperones 2002; 7:200-206

190. van der Bruggen T, Nijenhuis S, van Raaij E, et al. Lipopolysaccharideinduced tumor necrosis factor alpha production by human monocytes involves 
the raf-1/MEK1-MEK2/ERK1-ERK2 pathway. Infection and immunity 1999; 67:3824-3829

191. Pearson G, Robinson F, Beers Gibson T, et al. Mitogen-activated protein (MAP) kinase pathways: regulation and physiological functions. Endocr Rev 2001; 22:153-183

192. Kaiser F, Cook D, Papoutsopoulou $S$, et al. TPL-2 negatively regulates interferon-beta production in macrophages and myeloid dendritic cells. J Exp Med 2009; 206:1863-1871

193. Gatto G, Rossi A, Rossi D, et al. Epstein-Barr virus latent membrane protein 1 trans-activates miR-155 transcription through the NF-kappaB pathway. Nucleic Acids Res 2008; 36:6608-6619

194. Monk CE, Hutvagner G, Arthur JS. Regulation of miRNA transcription in macrophages in response to Candida albicans. PLoS One 2010; 5:e13669

195. Zhou H, Huang X, Cui H, et al. miR-155 and its star-form partner miR-155* cooperatively regulate type $\mathrm{I}$ interferon production by human plasmacytoid dendritic cells. Blood 2010; 116:5885-5894

196. O'Connell RM, Taganov KD, Boldin MP, et al. MicroRNA-155 is induced during the macrophage inflammatory response. Proc Natl Acad Sci U S A 2007; 104:1604-1609

197. Trotta $R$, Chen L, Ciarlariello D, et al. miR-155 regulates IFN-gamma production in natural killer cells. Blood 2012; 119:3478-3485

198. McCoy CE, Sheedy FJ, Qualls JE, et al. IL-10 inhibits miR-155 induction by toll-like receptors. J Biol Chem 2010; 285:20492-20498

199. Tracey KJ, Beutler B, Lowry SF, et al. Shock and tissue injury induced by recombinant human cachectin. Science 1986; 234:470-474

200. Frohlich D, Wittmann S, Rothe $G$, et al. Mild hyperthermia down-regulates receptor-dependent neutrophil function. Anesthesia and Analgesia 2004; 99:284292

201. Gavva NR, Bannon AW, Surapaneni S, et al. The vanilloid receptor TRPV1 is tonically activated in vivo and involved in body temperature regulation. The Journal of neuroscience 2007; 27:3366-3374

202. Gavva NR. Body-temperature maintenance as the predominant function of the vanilloid receptor TRPV1. Trends Pharmacol Sci 2008; 29:550-557 
203. Clark N, Keeble J, Fernandes ES, et al. The transient receptor potential vanilloid 1 (TRPV1) receptor protects against the onset of sepsis after endotoxin. FASEB J 2007; 21:3747-3755

204. Fernandes ES, Liang L, Smillie SJ, et al. TRPV1 deletion enhances local inflammation and accelerates the onset of systemic inflammatory response syndrome. J Immunol 2012; 188:5741-5751 


\section{APPENDIX: ABBREVIATIONS}

\section{General Abbreviations}

CARS Compensatory Anti-inflammatory Response Syndrome

MODS Multiple Organ Dysfunction Syndrome

SCIP Surgical Care Improvement Project

SIRS Systemic Inflammatory Response Syndrome

SSI Surgical Site Infection

\section{Cell Biology}

Ago2 Argonaute 2; cleaves mRNA as part of the RISC

HUVEC Human Umbilical Vein Endothelial Cell

miRNA microRNA: short, single stranded RNA

mRNA messenger RNA: longer, single stranded RNA; serves as template for

protein translation 
PBMC Peripheral Blood Mononuclear Cells

PDCD4 Programmed Cell Death Protein 4; target of miRNA-21

RISC RNA-induced silencing complex

siRNA silencing RNA

SHIP-1 SH2-domain containing inositol 5' phosphatase 1; target of miRNA-

155 and inhibitor of the TLR-4 pathway

SOCS-1 Suppressor of Cytokine Signaling 1; target of miRNA-155 and inhibitor of the TLR-4 and JAKISTAT

THP-1 Human monocytic cell line

TRPV1 Transient receptor potential cation channel subfamily $V$ member 1 ; a temperature sensitive plasma membrane channel, which may contribute to the effects of hypothermia

\section{Immunology}

Alarmins Endogenous proteins, which indicate tissue destruction or danger such as HSP or HMGB1

CD14 Cluster of Differentiation 14; marker for monocytes 
CD16 Cluster of Differentiation 16; low affinity Fcy-Receptor Marker for a subtype of inflammatory monocytes

DAMP Danger Associated Molecular Pattern; includes Alarmins and PAMPs

GM-CSF Granulocyte-macrophage colony-stimulating factor

HLA-DR Human Leukocyte Antigen DR; subtype of MHC II correlates with outcome in surgical patients

HMGB1 High-Mobility Group Protein B1; an alarmin

HSP Heat Shock Proteins; serve as alarmins

IFN- $\gamma \quad$ Interferon- $\gamma ;$ immune stimulatory cytokine

IL-6 Interleukin-6; pro-inflammatory cytokine

IL-10 Interleukin-10; anti-inflammatory cytokine

LPS Lipopolysaccharide; part of the outer membrane of gram-negative bacteria; is a DAMP

MHC II Major Histocompatibility Complex II; expressed on Antigen Presenting Cells and is necessary for stimulation of $\mathrm{T}$ - and $\mathrm{B}$-cells

NOD Nucleotide Oligomerization Domain Receptor, a PRR

PAMP Pathogen Associated Molecular Pattern; bacterial or viral 
Products, which are recognized by the immune system

PRR Pathogen Recognition Receptor; receptors, which recognizes DAMPs such as TLR-4 and NODs

RAGE Receptor for Advanced Glycation End Products, a PRR

ROS Reactive Oxygen Species; produce by immune cells in order to destroy bacteria

TLR-4 Toll-Like Receptor 4; well described PRR, which recognizes LPS, HMGB1 and HSP

TNF- $\alpha$ Tumor Necrosis Factor $\alpha$; pro-inflammatory cytokine

\section{Pathways}

ATF-1 Activated Transcription Factor 1; produces pro-inflammatory cytokines

DUSP-1 Dual Specificity Phosphatase 1; target of miRNA-101 and inactivator of $p 38$ and JNK of the MAPK

Erk Extracellular Signal Related Kinase pathway; part of the MAPK and important for $\mathrm{IL}-10$ production

IKK Inhibitory Kappa Kinase; activator of NFKB IKß Inhibitory kappa protein Beta; inactivates NFK $\beta$ 
IRAK $1 / 2$ Interleukin-1 Receptor associated Kinase 1/2; central signaling protein of the TLR-4 pathway

JNK c-Jun N-terminal Kinase pathway, part of the MAPK pathway

MAPK Mitogen Activated Protein Kinases pathway; central stress response pathway and part of the TLR-4 signaling; consisting of p38, JNK and Erk

MyD88 Myeloid differentiation primary response gene 88; central signaling protein of TLR-4

NFKB Nuclear Factor Kappa Beta; a central stress responsepathway and part of the TLR-4 signaling; consisting of the p65 and p50 subunits p38 part of the MAPK pathway

TAB2 TGF-beta activated kinase 1/MAP3K7 binding protein 2; target of miRNA-155 and part of the MAPK pathway

TAK1 TGF-beta activated kinase 1; part of the MAPK pathway

TRAF6 TNF-Receptor Associated Factor; central signaling protein of the TLR4 pathway 


\title{
CURRICULUM VITAE
}

\author{
Name: $\quad$ Adrian Theophil Billeter \\ Date of birth: $\quad$ April 29, 1984 in Kilchberg, Switzerland \\ Marital status: $\quad$ Single \\ Address: $\quad 3055$ Ledgebrook Court \\ Louisville, KY, 40241 \\ Phone: $\quad+1(502) 2960650$ \\ E-mail: atbill02@louisville.edu \\ adrianbilleter@bluewin.ch
}

\section{Education}

$1991-1998$

Primary education, Wädenswil, Switzerland

$1998-2002$

B.A., Kantonsschule Stadelhofen, Zurich, Switzerland

$2002-2008$

M.D., University of Zurich, Medical School, Switzerland

$2010-2012$

PhD program, Department of Physiology, University of Louisville Medical School, Louisville, Kentucky

\section{Training}

$2006 / 2007$

Practical year as medical student 


\begin{abstract}
9/2008-08/2010 Surgical residency, Department of Trauma Surgery, University of Zurich (O. Trentz, M.D. / H.-P. Simmen, M.D.)

08/2010 - present Drs. James and Emmeline Ferguson Fellow co-sponsored by the Royal College of Surgeons of Edinburgh

Price Institute of Surgical Research, Hiram C. Polk Jr. M.D. Department of Surgery, University of Louisville School of Medicine
\end{abstract}

\author{
Licensure and Certification \\ 2008 M.D. (Swiss Ministry of Health Certification) \\ $2006 \quad$ USMLE (ECFMG Step I)
}

\title{
Academic Appointments
}

2009

M.D.-Thesis:

School of Medicine, University of Zurich, Switzerland "Early

Serum Procalcitonin, IL-6 and 24-hour Lactate Clearance: Useful

Indicators of Septic Infections in Trauma Patients"

(Mentor: M. Turina M.D., PhD / M. Keel M.D.)

2012 Ph.D. Thesis:

Department of Physiology and Biophysics, School of Medicine, University of Louisville, Kentucky, United States of America "Pivotal Role of Interleukin-10 on MicroRNA-155 Expression in Regulation of the Monocyte Response in Hypothermia" (Mentor: Hiram C. Polk Jr., M.D.) 


\section{Publications:}

1. Early Serum Procalcitonin, IL-6 and 24-hour Lactate Clearance: Useful Indicators of Septic Infections in Trauma Patients

Billeter A, Turina M, Seifert B, Mica L, Stocker R, Keel M

World J Surg. 2009 Mar;33(3):558-566.

2. MicroRNAs: New Helpers for Surgeons?

Billeter AT, Druen D, Kanaan ZM, Polk HC Jr.

Surgery 2012 Jan;151(1):1-5. Epub 2011 Oct 22

3. Hyperfibrinolysis Diagnosed by Rotational Thromboelastometry

(ROTEM®) Is Associated with Higher Mortality in Patients with Severe

Trauma

Theusinger OM, Wanner GA, Emmert MY, Billeter A, Eismon J, Seifert B, Simmen HP, Spahn DR, Baulig W.

Anesth Analg. 2011 Nov;113(5):1003-1012

4. Damage control in severely injured trauma patients - A ten-year experience.

Frischknecht A, Lustenberger T, Bukur M, Turina M, Billeter A, Mica L, Keel M.

J Emerg Trauma Shock. 2011 Oct:4(4):450-4.

5. Mortality After Elective Colon Resection: The Search For Outcomes That Define Quality In Surgical Practice

Billeter AT, Polk HC, JR., Hohmann SF, Qadan M, Fry DE, Jorden JR, McCafferty MH, Galandiuk S

J Am Coll Surg. 2012 Apr;214(4):436-43; discussion 443-4

6. Opportunities for Improved Trauma Care of the Elderly - A Cohort Study of 2090 Severely Injured Patients

Schönenberger A, Billeter AT, Seifert B, Neuhaus V, Trentz O, Turina M Arch Gerontol Geriatr. 2012 Mar 30. [Epub ahead of print]

7. Obese trauma patients are at increased risk of early hypovolemic shock: a retrospective cohort analysis of 1084 severely injured patients.

Nelson J, Billeter AT, Seifert B, Neuhaus V, Trentz O, Hofer C, Turina M. Crit Care. 2012 May 8;16(3):R77. [Epub ahead of print]

8. Does Clinically-Relevant Temperature Range Change miRNA and Cytokine Expression in Whole Blood?

Billeter AT, Qadan M, Druen D, Gardner SA, The T, Polk HC Jr. J. of Interferon and Cytokine Research - Accepted for Publication 
9. Serial Lactate Measurements and Admission-SOFA-Score Predict Outcome in Severely Injured Patients

Dübendorfer C, Billeter AT, Seifert B, Keel M, Turina M

European Journal of Trauma and Emergency Surgery - Accepted for Publication

10. MicroRNAs as a New Factor in Lung and Esophageal Cancer

Billeter AT, Barnett R, Druen D, Polk HC Jr., Van Berkel V

Seminars in Thoracic and Cardiovascular Surgery - Accepted for

Publication

11. Sequential Improvements in Organ Procurement Increase the Organ

Donation Rate: A 20-Year Cohort Study

Billeter AT, Sklare S, Franklin GA, Wright J, Morgan G, O'Flynn PE, Polk $\mathrm{HC} \mathrm{Jr}$.

Injury - Accepted for Publication

12. Differential MicroRNA Expression Could Explain Microbial Tolerance in a Novel Chronic Peritonitis Model

Kanaan Z, Barnett R, Gardner S, Keskey B, Druen D, Billeter AT, Cheadle WG Innate Immunity - Accepted for Publication

13. Video Assisted Thoracoscopy: An Important Tool for Trauma Surgeons Billeter AT, Druen D, Franklin GA, Smith JW, Wrightson W, Richardson JD Under Review - Langenbeck's Archives of Surgery

\section{Manuscripts in Preparation}

14. Interfacility Transport Influences Outcome and Costs in Severely Injured Patients

Billeter AT, Polk HC Jr, Bowen W, Coleman R, Stephens M, Postel GC, Harbrecht BG, Smith JW, Franklin GA, Trunkey DD In preparation

15. Unintentional Intraoperative Hypothermia is Associated with Severe Complications and High Mortality Billeter AT, Cannon RM, Druen D, Hohmann SF, Polk HC Jr. In preparation

16. Pivotal Role of Interleukin-10 on MicroRNA-155 Expression in Regulation of the Monocyte Response in Hypothermia Billeter AT, Druen D, Gardner SA, Bhatnagar A, Spite MR, Hellmann J, Polk HC Jr. In preparation 


\section{Book Chapters:}

1. Traumatic Colorectal Injuries, Foreign Bodies, and Anal Wounds Galandiuk S, Smith J, Billeter A, Jorden J. In: Shackelford's Surgery of the Alimentary Tract. 7th edition Yeo C, McFadden D, Mathews J, Peters J, Pemberton J (Eds.) Elsevier, Philadelphia, PA. In Press.

2. Surgical Immunology Cheadle WG, Kanaan ZM, Billeter AT, Barnett RE In: Surgical Infections, $2^{\text {nd }}$ Edition Donald E. Fry (Editor) In Press

\section{Published Abstracts \& Posters (Selected):}

Admission Serum Procalcitonin and IL-6 Levels, but not Serum Lactate or Time of Lactate Clearance Correlate with Major Infection in 1079 Severely Traumatized Patients

Turina M, Billeter A, Mica L, Lustenberger Th, Trentz O, Keel M Inflamm Res., Supplement 2, S104 (A80)

Trauma, Shock, Inflammation and Sepsis, $7^{\text {th }}$ World Congress, Munich, March 2007

Improvements Achieved and Lessons Learned within 10 Years of Damage Control Surgery at a Swiss National Trauma Center

Turina M, Billeter A, Stocker R, Simmen HP, Keel M Br J Surgery 2009 May; 96 (S3): 1-26, p12

Serial Lactate Measurements and Admission-SOFA-Score Predict Outcome in Severely Injured Patients

Billeter A, Dübendorfer C, Neuhaus V, Seifert B, Simmen HP, Keel M, Turina M Trauma, Shock, Inflammation and Sepsis, $8^{\text {th }}$ World Congress, Munich, March 2010 


\section{Oral Presentations (Selected):}

Serial Lactate Measurements and Admission-SOFA-Score Predict Outcome in Severely Injured Patients

Billeter A, Dübendorfer C, Neuhaus V, Seifert B, Simmen HP, Keel M, Turina M Trauma, Shock, Inflammation and Sepsis, $8^{\text {th }}$ World Congress, Munich, March 2010

Risks and Challenges in Trauma of the Elderly - An Analysis of 1798 Severely Injured Patients

Billeter AT, Schönenberger A, Wanner GA, Simmen HP, Turina M Swiss Surgical Society Annual Meeting 2010 German Association for the Surgery of Trauma Annual Meeting 2010

The Influence of Obesity on Treatment and Short-Term Outcome of Severely Injured Patients

Billeter A, Nelson J, Turina M, Simmen HP, Wanner GA

Swiss Surgical Society Annual Meeting 2010

German Association for the Surgery of Trauma Annual Meeting 2010 